Department of Zoology, University of Ghana, Accra, Ghana \&

Museum of Zoology, University of Bergen, Norway.

\title{
A REVIEW OF AFROTROPICAL RHEOTANYTARSUS THIENEMANN ET BAUSE, 1913
}

\author{
(DIPTERA: CHIRONOMIDAE)
}

\begin{abstract}
Kyerematen, R. A. K. \& O. A. Sæther. 2000. A review of Afrotropical Rheotanytarsus Thienemann et Bause, 1913 (Diptera: Chironomidae). - Tijdschrift voor Entomologie 143: 27-69, figs. 1-163, tables 1-19. [ISSN 0040-7496]. Published 5 July 2000.

Twelve new Afrotropical species are described, R. kjaerandseni sp. n., as male, female, pupa and larva; $R$. longicornus sp. n. and $R$. transversus sp. n. as female and pupa; $R$. acuminatus sp. n., $R$. plerunguis sp. n., $R$. remus sp. n., $R$. bufemoratus sp. n., $R$ abonae sp. n., $R$. aquilus sp. n., $R$. atrius sp. n., $R$. digitatus sp. n. and $R$. jongkindi sp. n. as males only. Eight species are redescribed, $R$. rioensis Langton et Armitage, as male, female, pupa and larva; $R$. guineensis Kieffer as male, female and pupa; $R$. ororus Lehmann, as male, pupa and larva; $R$. fuscus (Freeman) as male and pupa; $R$. angustus (Freeman) comb. n. and $R$. ceratophylli (Dejoux) as male and female; $R$. samaki Lehmann, as male and pupa; $R$. montanus Lehmann, as male only. $R$. buculicaudus Kyerematen described in Kyerematen, Sæther \& Andersen (2000) is illustrated.

The genus has been recently divided into 21 species groups of which 10 have Afrotropical representatives, namely the pentapoda, acuminatus, photophilus, globosus, pellucidus, guineensis, trivittatus, ororus, thermae and phaselus groups. Keys to males, females and pupae of Rheotanytarsus from the Afrotropical region are given and the zoogeography discussed. The genus as a whole probably originated at the very end of the fragmentation of Pangaea. The Afrotropical species show warm / eurythermic vicariant Gondwanan patterns with multiple sister group relationships between the Afrotropical and the Sino-Indian region, African - West Palaearctic vicariance patterns, and limited evidence for West African - Brazilian vicariance patterns. Correspondence: O. A. Sæther, Department of Zoology, Museum of Zoology, University of Bergen, N- 5007 Bergen, Norway. E-mail: ole.sather@zmb.uib.no

Key words. - Chironomidae; Rheotanytarsus; Afrotropical; keys; new species; revision.
\end{abstract}

The major studies of benthic communities in West Africa have been mostly limited to standing waters and large rivers. The benthic fauna of the Volta Lake was studied by Petr (1969), of Lake Bosomtwe in Ghana by Whyte (1975), Kariba Lake in Nigeria by McLachlan (1965, 1969), and Lake Chad by Dejoux (1968) and Hopson (1967).

Some chironomid records from various parts of Ghana can be found in Amakye (1993). Thomas (1966) recorded 17 species of chironomids from a small man-made lake, Petr (1970) reported 52 species of chironomids from the Volta Lake, while Whyte (1971) studied the ecology of chironomids in a small tropical man-made lake, the Danfa reservoir and recorded 69 species. The chironomid larvae collected by Hynes (1972) were identified only to the subfamily level. Whyte (1980) in his studies from all over Ghana recorded 34 species of chironomids. According to Amakye (1993) 87 species in 31 genera belonging to 3 subfamilies had been recorded from Ghana by 1993 . The subfamilies were represented by 12 species (14\%) of Tanypodinae, 6 species (7\%) of Orthocladiinae and 69 species $(79 \%)$ of Chironominae.

Up till now little has been published on the Afrotropical species of Rheotanytarsus (Dejoux 1973; Freeman 1954, 1955, 1958; Kieffer 1918; Lehmann 1979). Only seven species have previously been described from the Afrotropical region, namely Rheotanytarsus angustus (Freeman 1955) comb. n.; Rheotanytarsus ceratophylli (Dejoux 1973); R. fuscus (Freeman 1954), R. guineensis Kieffer, 1918; R. montanus Lehmann, 1979; $R$. ororus Lehmann, 1979; and R. samaki Lehmann, 1979. None of these have previously been recorded from Ghana.

Several new species were found in Ghana during the collection done in connection with the Norwegian University Committee for Development, Research and Education (NUFU) project in Ghana. Other new 
species and new records are from Tanzania, Uganda, Gabon, South Africa, Senegal, Nigeria and Kenya.

World-wide, 94 species of Rheotanytarsus have been described, 26 from the Palaearctic region, 9 species from the Australian region, 25 species from the Oriental regions, 19 species from the Neotropical, 21 species from the Afrotropical region and 4 species from the Nearctic region (Kyerematen \& Sæther 2000). Some of the species occur in more than one region.

The larvae of the genus Rheotanytarsus live in flowing waters and also occur in the wave swept littoral zones of lakes, where they live as filter feeders using nets suspended between arms at the anterior end of the cases (see e.g. Thienemann 1954, Kullberg 1988).

Sæther \& Kyerematen (2000) did a phylogenetic analysis of the genus arriving at a preferred cladogram with twenty-one species groups. Area cladograms both of the genus as a whole and of the major separate groups were erected, and geographic coevolutionary analysis, and ancestral area analyses performed.

\section{METHODS, MORPHOLOGY AND TERMINOLOGY}

Morphological nomenclature follows Sæther (1977, 1980) with the additions mentioned in Sæther (1990a, b).The broad flattened setae of the pupal exuviae are called taenia(e) in accordance with Langton (1994).

\section{MATERIAL}

The material examined mostly consists of Ghanaian specimens of Rheotanytarsus collected during the NUFU programme. In addition, specimens from Tanzania, collected during an expedition by the Museum of Zoology, University of Bergen, to Northeast Tanzania in 1990 as well as material from Gabon and specimens of $R$. ceratophylli Dejoux from Senegal lodged in the Museum (ZMBN) have been examined. In addition material from the collections of $\mathrm{A}$. D. Harrison, South Africa (ADH), P. H. Langton, Northern Ireland (PHL) and J. Mobayed, France (JM) were examined.

From Institut Royal des Sciences Naturelles de Belgique (IRSN), Brussels, two specimens of $R$. angustus as well as four specimens misplaced as $R$. angustus (Freeman) were examined, and one specimen of the same species from Musée Royal de L'Afrique Centrale, Tervuren, Belgium (MRAC) was also examined. From The Natural History Museum, London (BMNH) 15 Rheotanytarsus specimens from Africa were borrowed and examined; most misplaced as $R$. guineensis Kieffer, $R$. fuscus (Freeman) and $R$. angustus (Freeman). Also examined was material from Zoologisches Staatsammlung, Munich, Germany (ZSM). This consisted of two specimens of $R$. montanus and one specimen of $R$. ororus Lehmann from D. R. Congo, used in the de- scriptions below, two specimens of $R$ angustus (Freeman) from South Africa, 1 specimen of $R$. guineensis Kieffer from Kenya, and one specimen of a new species from D. R. Congo.

The holotypes of the new species are deposited at the Museum of Zoology, University of Bergen (ZMBN) or at The Natural History Museum (British Museum), London, England (BMNH). Paratypes are deposited at the Zoology Department, University of Ghana, Legon, Accra (ZDUG); Zoologisches Staatsammlung, Munich (ZSM); The Natural History Museum (British Museum); R. M. Bohart Museum of Entomology, Davis, California (RMB); the collection of Peter Langton, Coleraine, Londonderry, Northern Ireland; and the Museum of Zoology, University of Bergen, Bergen (ZMBN).

\section{LOCALITIES}

Collections of the insects were made from various localities in Ghana and Rheotanytarsus spp. were taken in seven localities:

Agumatsa Stream originates in Togo and runs southwards through the Agumatsa Wildlife Sanctuary in the Wli area in the Volta Region of Ghana. The upper parts of the river has two large cascades and is rather fast flowing with stone and gravel as bottom substrate. In this section the river is approximately $5 \mathrm{~m}$ wide and quite shallow. Further downstream the river is flowing more slowly and the bottom material consists of sand and mud. According to Hall \& Swaine (1981) the forests in the area belong to the Dry SemiDeciduous Fire Zone subtype. The sanctuary is surrounded by steep-sided hills, the upper levels of which are covered by savannah woodland, while the bottom of the riverain valleys are covered by dense moist semideciduous forest. Mean annual rainfall exceeds 1500 $\mathrm{mm}$ especially in the higher hills in the Volta Region (Hall \& Swaine 1981).

Ankasa Game Production Reserve is located in the south western corner of Ghana in the Western Region close to the Ghana-Ivorian border. This part of Ghana lies within the Wet Evergreen forest type (Hall \& Swaine 1976). The area has an annual rainfall in excess of $1750 \mathrm{~mm}$ and in some places even higher than $2000 \mathrm{~mm}$ (Hall \& Swaine 1981). Many streams and small rivers run through the reserve, both rather fast flowing with stony substratum and more slow flowing with muddy or sandy substratum.

Boti Waterfalls is located in the Eastern Region of Ghana and lies within the Moist Semi-Deciduous southeast subtype (Hall \& Swaine 1976). Annual rainfall in this area is between 1200 and $1800 \mathrm{~mm}$. The Boti River cascades down into a ravine from where it continues down the valley. The trappings were done below the waterfall. Here the river forms a 
small, rather shallow dam with sandy bottom. Closer to the waterfalls there are rocks and stones. Downstream the river flows rather rapidly and the bottom substratum consists both of sand and gravel and of larger stones and rocks.

Densu River near Weija is located in the Accra plains in the Greater -Accra Region. The river is a large river which drains into the Volta Lake and has many tributaries. Vegetation in this area is of the Grassland Savannah type. Trees here are small in stature and sparsely distributed. The ground is covered by tall grasses and rainfall is very minimal. The area of the Densu river near Weija is surrounded by gentle-sloping hills which are part of the Akuapim Range.

Kakum National Park is located north-west of Cape-Coast in the Central Region. According to Hall \& Swaine (1976), this area falls within the Moist Evergreen forest type. Annual rainfall varies between 1200 and $1800 \mathrm{~mm}$. In the park there are many streams and small rivers, mostly rather slow-flowing with sandy substratum.

Kintampo Falls is located in the Brong-Ahafo Region. The locality is situated just north of the Dry Semi-Deciduous Fire Zone forest subtype and is thus somewhat influenced by this type of vegetation. Rainfall in this area, unlike that of the higher hills of the Volta region, do not exceed $1000 \mathrm{~mm}$ annually (Hall \& Swaine 1981). Chironomids were trapped just below the cascade and here the river is fast flowing with rocky and stony bottom substratum.

Subri River is a big river draining into the Volta Lake. The trappings were done near Kibi, located in The Eastern Region. The area lies within the Upland Evergreen forest type, which occur in isolated hill ranges (500-750 $\mathrm{m}$ elevations) within the Moist Semi-Deciduous forest type (Hall \& Swaine 1981). The hills here are isolated and steep-sided with more or less flat summits. Elevation of the hill summits leads to reduced temperatures, increased rainfall and mistiness. The forest is uneven and the soil covered by dense thicket or grassland in drier areas.

The area of tropical rain forest in Eastern Africa is not large, approximately $10,000 \mathrm{~km}^{2}$, a mere $0.1 \%$ of the estimated 10 million $\mathrm{km}^{2}$ of tropical rain forest in the world (Mabberley 1992). The forests of eastern Africa are highly fragmented - discrete islands associated with localised areas of high rainfall, surrounded by a sea of comparatively arid woodland. Contrasts between these wet and dry areas are pronounced unlike the vast western and central African forests (Wasser \& Lovett 1993). Climatic vicissitudes throughout the Pleistocene are thought to have caused major extinctions by substantially reducing the total area of rain forest. However, the forest patches of eastern Africa appear to have escaped these changes owing to the remarkable stability of the Indi- an ocean currents that bring moisture to the tropical east African coast (Hamilton 1982).

The material of Rheotanytarsus from Tanzania originates from two localities. Most of the species were collected from and around the Kaputu Stream, near Mazumbai in the West Usumbara Mountains, Tanga Region, in north-eastern Tanzania. The trapping sites along the stream are described by Andersen \& Johanson (1993). The West Usumbara Mountains belong to the Eastern Arc, a chain of mountains stretching along the east coast of Tanzania. The mountains are covered with montane evergreen forest and due to a stable and most favourable coastal climate these forests are considered to be very old and are among the most interesting endemic centres in Africa (Kingdon 1990). One species was taken at the outskirts of the city of Arusha, Arusha Region, in Northern Tanzania at a small, rapidly flowing river with stony substratum, originating in Mount Mehru.

Several other species were collected as well as examined from localities all over the African continent. In South Africa, new species and new records of some previously described species were collected from Kruger National Park in Eastern Transvaal and the Mooi River in the Natal Province. Both these localities appear to be part of a minor core area of endemism somewhat connected to the Eastern Arc of Tanzania (Hamilton 1989). In what Balinsky (1962) calls the 'drought corridor', a large region including most of Cape Province north and east of Cape Town, Namibia, Botswana, the western Orange Free State, the western and northern fringes of Transvaal and a broad belt extending north east and including most of Zambia and Zimbabwe and large parts of Tanzania, Kenya and Somalia, mountain and headwater streams dry up every annual dry season except, in rare cases, where they originate in permanent streams. In much of the Central African and some of the Transvaal parts of this corridor, the annual rainfall is not low, but it is so seasonal that practically no rain falls for at least three consecutive months of the dry season. Rainfall over much of Southern Africa is limited to a discrete rainy season and little or no rain may fall during four to six months of the year. Even in regions where the rainfall is moderate or even high, headwater streams dry up regularly during the dry season (Harrison 1966). Lowveld of Transvaal and coastal regions of Natal have tropical or subtropical climates (Harrison 1964).

The Olifantsvlei, is a marshy region 14 miles south west of Johannesburg situated at the confluence of the Klib and Klipspruit streams. Water trickles through reeds along the northern banks of the river. Peat bog overgrown with reeds are also found here (Harrison et al 1960).

In Gabon, one species was collected from the wall 
of Auberge St. Jean opposite the Ogooue' River in the Moyen-Ogooue' Region. This area is part of the dense Tropical Rain Forest of Western and Central Africa. The vegetation here is of the Moist Evergreen Forest at low and medium altitude. The CameroonGabon forest is one of the foci of isolated population of those many species which show disjunct distribution (Hamilton 1989). Leonard (1965) emphasised the richness in endemic species of the region between eastern Nigeria and Mayoumba, particularly the basin of the Ogooue' River.

Other new species were collected from Mt. Elgon in Bulambuli, Uganda; the Ogooue River in the Moyen -Ogooue' Region of Gabon; River Luoho in Irangi, D. R. Congo; the Letaba River in Eastern Transvaal; East Rand and the Olifants River all in South Africa. New records are also given for $R$. angustus from Kruger National Park, and Natal province in South Africa and Arusha in the Arusha Region of Tanzania; for $R$. ceratophylli from Kedougou Etiess, Senegal; and Kankiya and Zaria in Northern Nigeria; for $R$. fuscus from Lesotho in Southern Africa and for $R$. guineensis from the Letaba River in Eastern Transvaal and the Mooi River in the Natal Province, South Africa, Meru National Park in Kenya and the Kaputu Stream in the Tanga Region of Tanzania; for $R$. montanus from Natal Province in South Africa and for $R$. samaki from Lebanon.

\section{Rheotanytarsus Thienemann et Bause.}

Rheotanytarsus Thienemann et Bause in Bause 1913: 120. Syntanytarsus (Rheotanytarsus Thienemann et Bause), in Bause 1913: 120.

Tanytarsus (Rheotanytarsus) auct.

Rheotanytarsus Thienemann et Bause, Fittkau 1960: 397.

Type species: Tanytarsus pentapoda Kieffer, 1909, by subsequent designation of Goetghebuer (1954: 132).

Sæther \& Kyerematen (2000) give a generic diagnosis, a list of all described species, keys to known male imagines and pupae, and a phylogenetic analysis of the genus arriving at a preferred cladogram with twenty-one species groups. Area cladograms both of the genus as a whole and of each separate group were erected, geographic coevolutionary analysis, and ancestral area analyses performed.

Ten of the twenty-one species groups have Afrotropical representatives. Some of these groups have primarily Afrotropical representatives. Although keys are also given by Sæther \& Kyerematen (2000) it is regarded as advantageous also to have keys to the Afrotropical species.

\section{Key to male imagines of Afrotropical} Rheotanytarsus Thienemann et Bause.

1. Median volsella very long, extending at least slightly beyond apex of inferior volsella ............. 2

- Median volsella shorter, not extending beyond apex of inferior volsella ......................................

2. Median volsella with distal setae fused into narrow plate with or without apical points ............. 3

- Median volsella reaching far beyond apex of inferior volsella; with distal lamelliform setae never fused into plate; Ghana (figs. 43-46; Kyerematen, Sæther \& Andersen 2000: figs 49-51)

R. buculicaudus sp. $\mathrm{n}$.

3. Superior volsella with digitus not extending beyond margin; apex of anal point spatulate; plate of median volsella curved and knot-like; Ghana (figs. 136-139) ................. R. kjaerandseni sp. n.

- Superior volsella with digitus extending beyond margin; apex of anal point not spatulate, narrow or broad ............................................................ 4

4. Gonostylus abruptly narrowed in distal half, with parallel-sided apical portion; median volsella with plate without apical points; crest of anal point $\mathrm{V}$ shaped and open; apex of anal point narrow; Ghana (figs. 18-21) ....................R. remus sp. n.

- Gonostylus not abruptly narrowed; median volsella with plate with apical points; anal point apex broad; crest of anal point basally rounded; Ghana (figs. 156-159) ........... R. digitatus sp. n.

5. Tergite IX with posterior margin with pronounced shoulders to each side; median volsella not reaching apex of superior volsella; widespread Afrotropical (fig. 108-114).

R. ceratophylli (Dejoux)

- Tergite IX with posterior margin triangular, rounded, or at most straight; median volsella reaching or not reaching apex of superior volsella

6. Digitus of superior volsella well developed, extending beyond margin; median volsella at least reaching apex of superior volsella ..................... 7

- Digitus of superior volsella small or absent, not extending beyond margin; median volsella reaching or not reaching apex of superior volsella ... 10

7. Gonostylus abruptly tapered in apical portion, curved at apex; anal point broad; crest of anal point basally rounded; median volsella with foliate setae fused into several plates without apical points; widespread Afrotropical (figs. 72-75)........ ...R. guineensis (Kieffer).

- Gonostylus not abruptly tapered, not curved at apex; anal point narrow; crest of anal point $\mathrm{V}$ shaped and open; median volsella with foliate setae fused into one or several plates with or without apical points 
8. Superior volsella rounded or oblong; Uganda (figs. 31-34) ...................... R. bufemoratus sp.n.

- Superior volsella with knob- or hook-like posterior extension ...9

9. Anterolateral, lateral and posterior margins of superior volsella produced giving three very characteristic knob-like projections; median volsella relatively broad at apex, reaching slightly beyond apex of superior volsella with distal plates with apical points; D. R. Congo, Ethiopia (figs. 1-4) . R. samaki Lehmann

- Superior volsella sub-triangular, with posterior projection only; median volsella long and slender, almost reaching apex of inferior volsella with several ovoid distal plates without apical points; D. R. Congo, South Africa, Tanzania (figs. 22-25) . .R. angustus (Freeman)

10. Gonostylus abruptly tapered with curved apex; posterior margin of tergite IX straight with shoulders; median volsella shaped as an inverted L; Canary Islands, South Africa (figs. 84-87)

. $R$. rioensis Langton et Armitage

- Gonostylus not tapered or abruptly tapered, but without curved apex; posterior margin of tergite IX triangular or rounded; median volsella not shaped as an inverted $\mathrm{L}$

.. 11

11. Antenna with 12 flagellomeres; wing length less than $0.99 \mathrm{~mm}$; AR lower than 0.2 ; outer margin of sieve pore produced giving a pronounced projection; Ghana (figs. 101-107) ...... R. aquilus sp. n.

- Antenna with 13 flagellomeres; wing length usually more than $0.99 \mathrm{~mm}$; AR mostly higher than 0.2 ; outer margin of sieve pore without any projection

.. 12

12. Apex of anal point spatulate .......................... 13

- Apex of anal point not spatulate ...................... 15

13. Superior volsella rounded; anal point crest rounded, basally closed; pale; Ghana (figs. 132$135)$. R. atrius sp. n.

- Superior volsella long, ovoid or with knob-like posterior extension; anal point crest V-shaped and basally open ...14

14. Median volsella long, much longer than superior volsella; pale; Tanzania (figs. 47-53)

$R$. abonae Kyerematen, sp. $\mathrm{n}$.

- Median volsella short, much shorter than the elongate superior volsella; dark; Gabon, D. R. Congo (figs. 160-163) ........... R. jongkindisp. n.

15. Apex of anal point narrow and/or tapering .... 16

- Apex of anal point broad .................................. 17

16. Superior volsella with posterior extension; crest of anal point $\mathrm{V}$-shaped, open; median volsella with large foliate setae without apical points; AR about 0.1-0.2; D. R. Congo, Italy, S. Africa (figs. 5861) ............................. R. montanus Lehmann

- Superior volsella oblong without extension; crest of anal point rounded basally; median volsella club-shaped, with distal lamellae fused into plate with terminal points; AR about 0.5 ; D. R. Congo (figs. 120-123) $R$. ororus Lehmann

17. Superior volsella oblong; median volsella strongly S-shaped; AR about 0.8-0.9; basal tergite bands absent; Tanzania (figs. 14-17)

R. plerunguis sp. n.

- Superior volsella with posterior extension ....... 18

18. Superior volsella with hooked apical extension; AR about 0.7-0.8; Tanzania (figs. 10-13)

$R$. acuminatus sp. $\mathrm{n}$.

- Superior volsella distinctly sickle-shaped; AR about 0.3-0.5; South Africa (figs. 51-53)

.R. fuscus (Freeman)

\section{Key to known females of Afrotropical} Rheotanytarsus Thienemann et Bause

1. Total length less than $2.0 \mathrm{~mm}$......................... 2

- Total length more than $2.0 \mathrm{~mm}$........................ 4

2. Gonocoxite with setae; seminal capsule less than $40 \mu \mathrm{m}$ long; Ghana (figs. 62-65)

$R$. transversus sp. $\mathrm{n}$.

- Gonocoxite without setae; seminal capsule at least $44 \mu \mathrm{m}$ long .............................................. 3

3. Setae on tergite IX at most 20; notum at least 90 $\mu \mathrm{m}$ long; widespread Afrotropical (figs. 115-119) R. ceratophylli (Dejoux)

- Setae on tergite IX at least 40; notum at most 76 $\mu \mathrm{m}$ long; Ghana (figs. 43-47)

R. kjaerandseni sp. n.

4. Seminal capsule with neck longer than $15 \mu \mathrm{m}$ long; South Africa, Canary Islands (figs. 88-92) . $R$. rioensis Langton et Armitage

- Seminal capsule with neck less than $13 \mu \mathrm{m}$ long

5. Thorax including postnotum dark; South Africa (figs. 35-39) $R$. longicornus sp. $\mathrm{n}$.

- Thorax including postnotum pale ..................... 6

7. Palpomere 5 more than $200 \mu \mathrm{m}$ long; D. R. Congo, Tanzania, South Africa (figs. 26-30)

R. angustus (Freeman)

- Palpomere 5 less than $150 \mu \mathrm{m}$ long; widespread Afrotropical (figs. 76-80) ... R. guineensis (Kieffer)

The female of $R$. montanus Lehmann is excluded from the key since no mensural features are given in Lehmann (1979) and it was not examined here.

Key to known pupae of Afrotropical Rheotanytarsus Thienemann et Bause

1. Spine patches on tergites II-V .......................... 2

- Spine patches on tergites II-VI .......................... 6

2. Tergite II with anterior paired patches and posterior shagreen; thoracic horn bare and without 

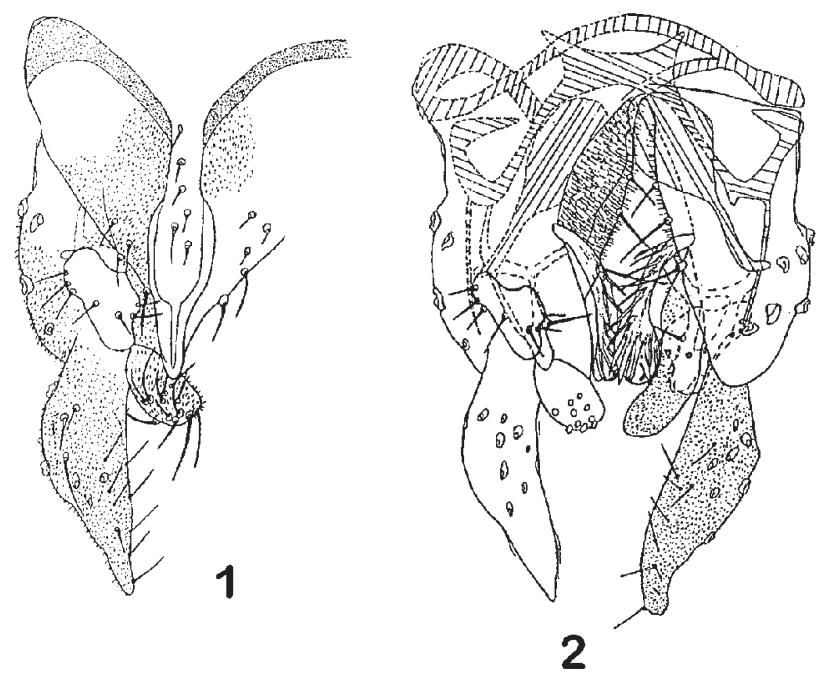

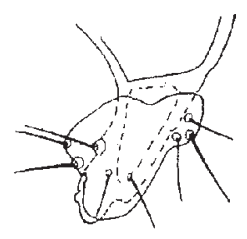

3

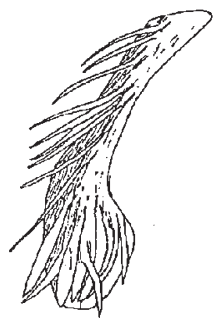

4

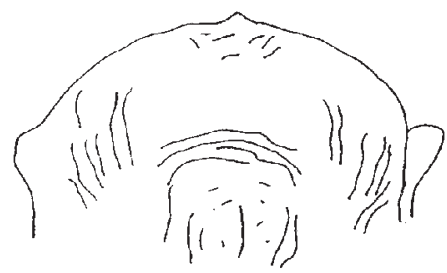

7



5

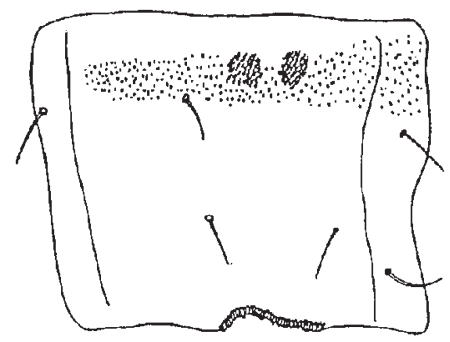

8

6

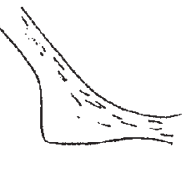

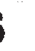




median bend; widespread Afrotropical (figs. 8183) R. guineensis Kieffer

- Tergite II with anterior paired spine patches and posterior shagreen arranged as two groups of spinule patches

3. Anal lobe with one dorsolateral seta; caudal hooklets about 30; Ghana (figs. 145-150).

R. kjaerandseni sp. n.

- Anal lobe bare, without dorsolateral seta.......... 4

4. Thoracic horn very long at least $600 \mu \mathrm{m}$ long; caudal hooklets more than 70; South Africa (figs. 40-42) $R$. longicornus sp. n.

- Thoracic horn less than $600 \mu \mathrm{m}$ long; caudal hooklets less than 70

5. Number of spinules in each spinule patch on tergite II about 65; caudal hooklets about 60; South. Africa (fig. 55-57) .............. R. fuscus (Freeman)

- Number of spinules in each spinule patch on tergite II about 40; caudal hooklets about 30; D. R. Congo (figs. 124-127) ......... R. ororus Lehmann

6. Spine patches on tergites II and III transverse, band-like, overlapping .................................... 7

- Spine patches on tergites II-VI all circular to elliptical ......

7. Tergite II with posterior patch of spinules; frontal apotome extensively rugulose in apical half; D. R. Congo, South Africa, Italy (Lehmann 1979 figs 204-206) R. montanus Lehmann

- Tergite II without posterior patch of spinules; frontal apotome less rugulose anteriorly; thoracic horn with fine spinules in apical half; Ghana (figs. 66-71) .R. transversus sp. n.

8. Segment VIII with single or cleft posterolateral spur (...9

- Segment VIII with posterolateral comb of 3-6 curved thorn-like spurs; thoracic horn with median bend and spines in apical 3/4 (Dejoux 1973: figs 11-17) .................... R. ceratophylli (Dejoux)

9. Thoracic horn completely bare; anal lobe with fringe of long taeniate setae; T VIII with L-setae; South Africa, Canary Islands (figs. 93-96) $R$. rioensis Langton et Armitage

- Thoracic horn with points in apical $1 / 3$; anal lobe with completely bare fringe; T VIII with no L-setae; Ethiopia, D. R. Congo, Lebanon (figs. 5-9) R. samaki Lehmann

\section{DESCRIPTIONS OF SPECIES}

\section{The pentapoda group}

The known pupae have thoracic horn without median bend with points in apical $1 / 4-1 / 2$, tergites II-VI with paired anterior circular patches of spines, tergite II bare or with posterior shagreen not arranged into two groups, and anal lobe without dorsal seta.
The male imagines of the group have basal tergite bands and V-shaped anal tergite bands; spatulate or narrow and tapering anal point with $\mathrm{V}$-shaped and open crest; superior volsella with reduced digitus except in $R$. samaki; median volsella extending beyond superior volsella, but not reaching apex of inferior volsella and with apical plates; and abruptly tapered gonostylus without parallel-sided apical portion except in $R$. samaki where the gonostylus is not abruptly tapered.

\section{Rheotanytarsus samaki Lehmann}

(figs. 1-9)

Rheotanytarsus samaki Lehmann, 1979: 65.

Material examined. - ETHIOPIA: Waldia, $2 \widehat{\jmath}$, as Tanytar sus (Rheotanytarsus) fuscus Freeman, 16-31 i $1936 \& 1-26$ ii 1936, W. S. Macfie (B. M. 1936-792) (BMNH). D. R. CONGO: Kalengo, holotype $\widehat{0}, 9$ v 1972, emergence, J. Lehmann, (ZSM Kat. - Nr: E1/1980). LEBANON: Bared River, 2 o, 1 mature $\delta$ pupa, 5 pupae, 10 xi 1996, J. Moubayed.

Diagnostic characters. - See keys.

\section{Male imago $(\mathrm{n}=4-6)$}

Total length $2.31-3.48,2.68 \mathrm{~mm}$. Wing length 1.44-1.50 (3) mm. Total length / wing length 1.541.60 (3). Wing length / length of profemur 2.17-2.24 (3). Thorax with dark brown vittae and postnotum, abdomen pale, legs pale with apical portion darker.

Head. AR 0.59-0.64, 0.61. Thirteenth flagellomere 250-312, $285 \mu \mathrm{m}$ long. Temporal setae 7-8, 7; including 3-4, 4 inner verticals; 2-3, 2 outer verticals; and 2 postorbitals. Clypeus with $17-31,21$ setae. Tentorium 84-110, $94 \mu \mathrm{m}$ long, 20-32, $27 \mu \mathrm{m}$ wide at sieve pore and $10-11,10 \mu \mathrm{m}$ wide at posterior tentorial pit. Stipes 100-132, $120 \mu \mathrm{m}$ long, 20-27, 25 $\mu \mathrm{m}$ wide. Palpomeres length (in $\mu \mathrm{m}$ ): $28-32,30 ; 29$ 38, 34; 100-126, 115; 108-112, 111; 204-208 (3). Fifth palpomere / third palpomere 1.65-2.04 (3).

Thorax. Dorsocentrals 9-17,12; acrostichals 22-28, 25. Scutellum with 5-9, 7 setae.

Wing, $\mathrm{n}=3$. VR 1.31-1.54. $\mathrm{R}$ with $18-25$ setae, $\mathrm{R} 1$ with 27-31, R4+5 with 54-67, Sc and M bare, RM with $0-1, M 1+2$ with $56-65, M 3+4$ with $36-39, \mathrm{Cu}$ with 18-20, Cu1 with 21-25, PCu with 47-52, and An with 31-38 setae. Cells $m$ with 37 setae, $r 4+5$ with about $400, \mathrm{~m} 1+2$ with about $400, \mathrm{~m} 3+4$ with 130 , cu with 154 and an with 100 setae.

Legs. Spur of front tibia 18-24, $20 \mu \mathrm{m}$ long; spurs of middle tibia 12-13 (2) and 16-18 (3) $\mu \mathrm{m}$ long, of hind tibia 16-20, 17 and 18-22, $20 \mu \mathrm{m}$ long; all excluding comb. Combs 13-20, $18 \mu \mathrm{m}$ long. Width at apex of front tibia 38-46, $42 \mu \mathrm{m}$; of middle tibia 36$42(3) \mu \mathrm{m}$, of hind tibia $40-49,45 \mu \mathrm{m}$.

Lengths and proportions of legs see table 1. 

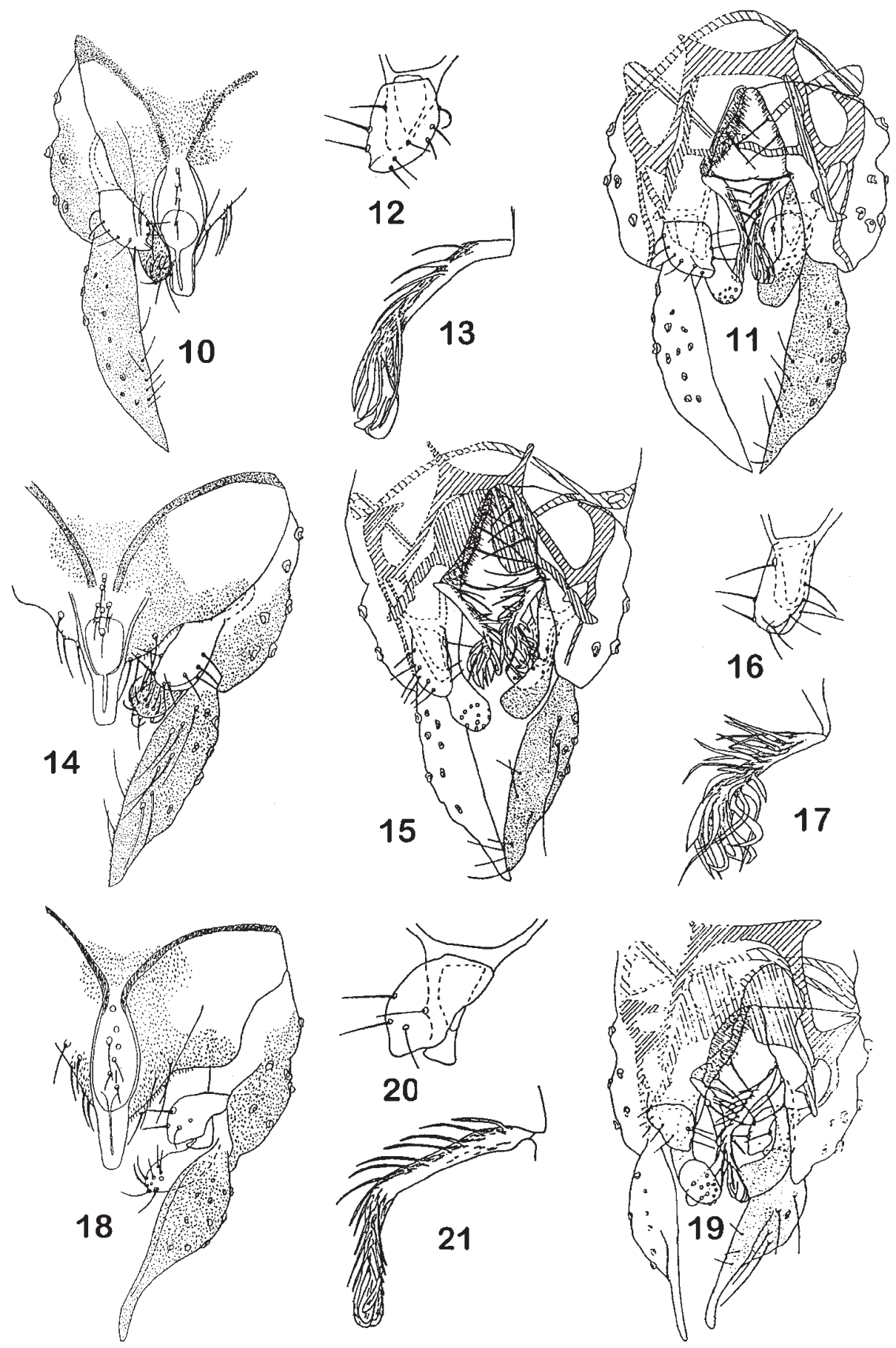

Figs. 10-13. Rheotanytarsus acuminatus sp. n., male imago. - 10, 11, hypopygium, dorsal and ventral view; 12 , superior volsella; 13, median volsella. - figs. 14-17. R. plerunguis sp. n., male imago. - 14, 15; hypopygium, dorsal and ventral view; 16, superior volsella; 17 , median volsella. - figs. 18-21. R. remus sp. n., male imago. $-18,19$, hypopygium, dorsal and ventral view; 20 , superior volsella; 21 , median volsella. 
Table 1. Rheotanytarsus samaki, male. Lengths (in $\mu \mathrm{m}, \mathrm{n}=1-4$ ) and proportions of legs:

\begin{tabular}{|c|c|c|c|c|c|c|}
\hline & $\mathrm{fe}$ & $\mathrm{ti}$ & $\mathrm{ta}_{1}$ & $\mathrm{ta}_{2}$ & $\mathrm{ta}_{3}$ & $\mathrm{ta}_{4}$ \\
\hline $\mathrm{p}_{1}$ & 664-740,688 & $352-460,407$ & $792-843$ & 408 & 304 & 240 \\
\hline $\mathrm{p}_{2}$ & $624-720$ & $480-580$ & $304-343$ & $160-168$ & $114-120$ & $71-80$ \\
\hline \multirow[t]{2}{*}{$\mathrm{p}_{3}$} & 704-780,729 & $616-740,674$ & $472-489$ & $256-268$ & $203-216$ & $125-128$ \\
\hline & $\mathrm{ta}_{5}$ & LR & BV & SV & BR & \\
\hline $\mathrm{p}_{1}$ & 96 & $2.11-2.25$ & 1.71 & 1.28 & - & \\
\hline $\mathrm{p}_{2}$ & $54-56$ & 0.63 & 3.38 & 3.63 & $4.0-5.0$ & \\
\hline $\mathrm{p}_{3}$ & $72-79$ & $0.72-0.77$ & $2.67-2.79$ & $2.80-2.85$ & $5.0-5.2$ & \\
\hline
\end{tabular}

Hypopygium (figs.1-4). Tergite IX with 7-14, 9 setae. Anal point 58-102, $76 \mu \mathrm{m}$ long; 22-54, $31 \mu \mathrm{m}$ wide at base; 4-12, $7 \mu \mathrm{m}$ wide at apex; crest V-shaped and open. Laterosternite IX with 1 seta. Phallapodeme 71-100, $87 \mu \mathrm{m}$ long; transverse sternapodeme 36-49, $43 \mu \mathrm{m}$ long. Gonocoxite 110-148, $126 \mu \mathrm{m}$ long; gonostylus 102-126, $109 \mu \mathrm{m}$ long. Superior volsella (fig.3) 35-52, $43 \mu \mathrm{m}$ long; ovoid, with posterior relatively strong hook-like to knob-like extension; inferior volsella 75-96, $86 \mu \mathrm{m}$ long; median volsella (fig.4) 6276, $67 \mu \mathrm{m}$ long; with lamelliform setae fused into plates with apical points. Inferior volsella with microtrichia, superior and median volsellae without microtrichia. HR 1.06-1.17, 1.12; HV 2.22-3.00, 2.45.

Pupa ( $\mathrm{n}=5$ except when otherwise stated)

Total length 3.04-3.54, $3.30 \mathrm{~mm}$. Exuviae slightly dark.

Cephalothorax. Frontal apotome (fig. 5) slightly wrinkled. No frontal setae. Thoracic horn (fig. 6) 140180, $158 \mu \mathrm{m}$ long; 20-24, $22 \mu \mathrm{m}$ wide; with fine spinules in its apical one third. Median antepronotals 7080 (2) $\mu \mathrm{m}$ long; lateral antepronotals not observable; median antepronotals taeniate. Precorneals taeniate, close together; anterior precorneals 30-50 (3) $\mu \mathrm{m}$ long; median precorneals 40-60, $50 \mu \mathrm{m}$ long; posterior precorneals 90-108 (3) $\mu \mathrm{m}$ long. Anterior dorsocentrals Dc1 16-22 (2) $\mu \mathrm{m}$ long; Dc2 36-44 (2) $\mu \mathrm{m}$ long; Dc3 24-32 (2) long; Dc4 12-36(2) $\mu \mathrm{m}$ long. Dc1 4 (2) $\mu \mathrm{m}$ in front of Dc2; Dc2 190-220 (2) $\mu \mathrm{m}$ in front of Dc3; and Dc3 3-4 (2) $\mu \mathrm{m}$ in front of Dc4. Nose of wing sheath (fig. 6) 4-12, 8 (4) $\mu \mathrm{m}$ long.

Abdomen (fig. 9). Tergite I bare; paired circular spine patches on tergites II-VI. Tergite II (fig. 8) bare posteriorly. Number of spines on T II-VI; 60-70 (3), 60-70 (2), 50-60 (3), 30-50 (3), 30-40 (2). Shagreen present anteromedially on tergites II-VIII. Caudal hooklets occupying about median half of T II, about 60-70 (3) hooklets. Caudal spur 14-20, $16 \mu \mathrm{m}$ long. Number of lateral setae on segments II-VII as 2-3, 23, 3, 3, 3, 3; no L-setae present on T VIII. All L-setae hairlike. Anal lobe completely bare, with no setae in fringe. Male genital sac overreaches anal lobe by 128 140 (3) $\mu \mathrm{m}$.

Distribution. - The species is known from Ethiopia, NE D. R. Congo and Lebanon.

\section{The acuminatus group}

The male imagines have a broad anal point with rounded and basally open or closed crest; median volsella extending beyond superior volsella, but not reaching apex of inferior volsella and with apical plates, with or without points; and gonostylus not abruptly tapered.

\section{Rheotanytarsus acuminatus sp. $\mathrm{n}$.}

(figs. 10-13)

Type locality. - TANZANIA: Tanga Region, W. Usambara Mts, Mazumbai, Kaputu Stream.

Type material. - Holotype ô, TANZANIA: Tanga Region, W. Usambara Mts, Mazumbai, Kaputu Stream, loc. 10, 1420 m a.s.l., xi 1990, Malaise trap, ZMBN's Tanzania expedition (ZMBN Type No. 313). Paratype: 10, Tanga Region, W. Usambara, Mazumbai, xi 1990, ZMBN Tanzania Exp. (ZMBN)

Diagnostic characters. - See key.

Etymology. - After the Latin acuminatus meaning pointed, sharpened; referring to the sharply pointed apex of the gonostylus.

Male imago $(n=2)$

All measurements and shapes within the range of $R$. angustus (Freeman) with the following exceptions and additions:

Wing length / length of profemur 1.87-1.97. Thorax pale brown, abdomen and legs pale.

Head. Palpomeres 3 to 5 lacking.

Wing. VR 1.47-1.54. Sc with 10-20 setae. Cells m with 25 setae, $\mathrm{r} 4+5$ with about $400, \mathrm{~m} 1+2$ with about $400, \mathrm{~m} 3+4$ with about 150 , cu with 128 and an with 71 setae. 

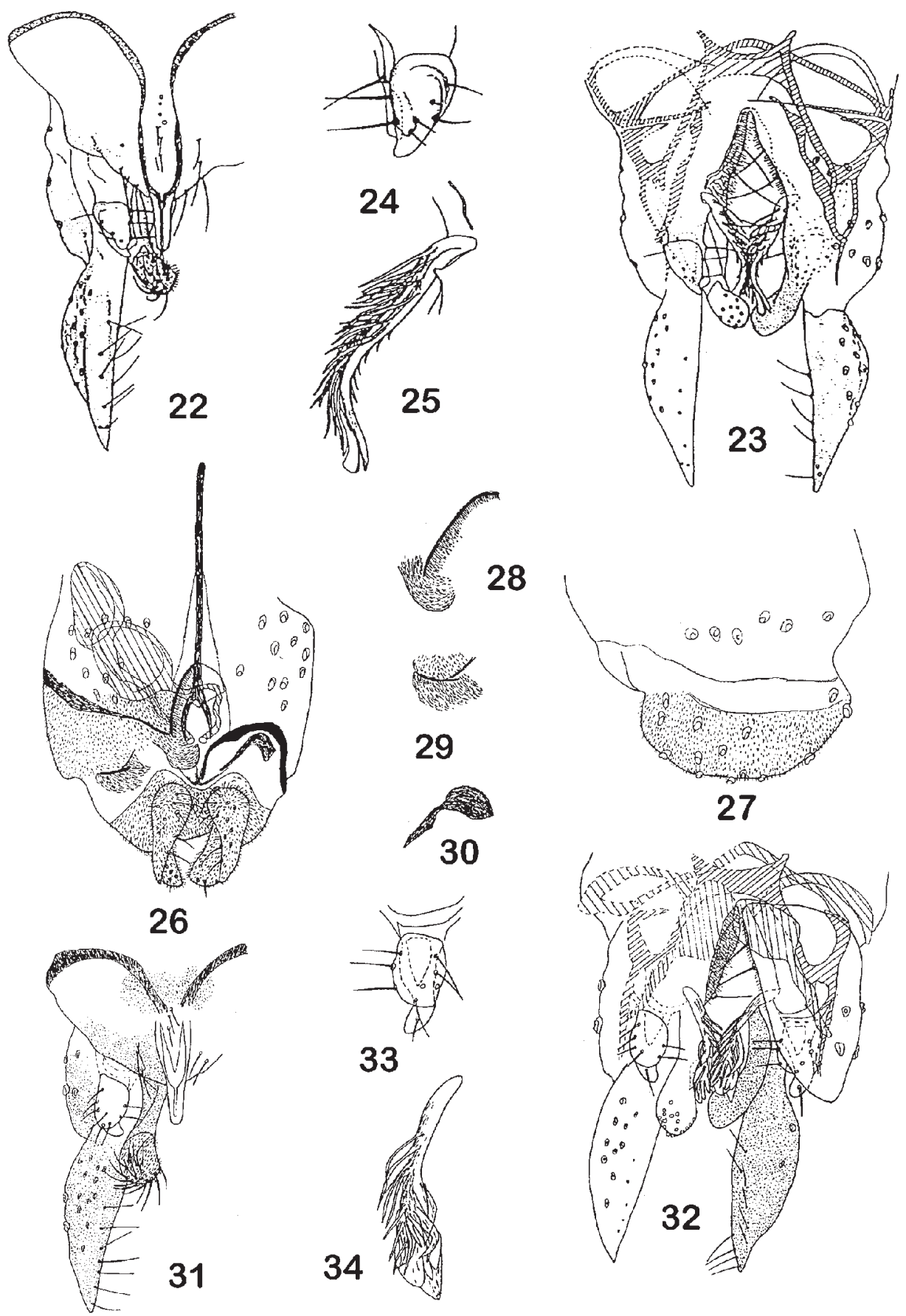

Figs. 22-30. $R$. angustus (Freeman), male and female imago. -22, 23, hypopygium, dorsal and ventral view; 24, superior volsella; 25, median volsella; 26, 27, female genitalia, ventral and dorsal view; 28, dorsomesal lobe; 29, ventrolateral lobe; 30, apodeme lobe. - figs. 31-34. R. bufemoratus sp. n., male imago. - 31, 32, hypopygium, dorsal and ventral view; 33, superior volsella; 34 , median volsella. 
Table 2. Rheotanytarsus plerunguis, male. Lengths (in $\mu \mathrm{m}$ ) and proportions of legs.

\begin{tabular}{|c|c|c|c|c|c|c|c|}
\hline & $\mathrm{fe}$ & $\mathrm{ti}$ & $\mathrm{ta}_{1}$ & $\mathrm{ta}_{2}$ & $\mathrm{ta}_{3}$ & $\mathrm{ta}_{4}$ & $\mathrm{ta}_{5}$ \\
\hline $\mathrm{p}_{1}$ & $893-911$ & $528-553$ & $1018-1036$ & $571-578$ & 386 & 307 & 171 \\
\hline $\mathrm{p}_{2}$ & $832-839$ & $678-682$ & 378 & 189 & 139 & - & - \\
\hline \multirow[t]{2}{*}{$\mathrm{p}_{3}$} & $968-982$ & $846-853$ & 553 & 364 & 300 & 193 & 96 \\
\hline & LR & BV & SV & BR & & & \\
\hline $\mathrm{p}_{1}$ & $1.87-1.93$ & 1.73 & $1.40-1.41$ & 4.5 & & & \\
\hline $\mathrm{p}_{2}$ & 0.55 & - & 4.02 & 5.5 & & & \\
\hline $\mathrm{p}_{3}$ & 0.65 & 2.50 & 3.30 & 7.5 & & & \\
\hline
\end{tabular}

Legs. Spurs of front tibia 20-29 $\mu \mathrm{m}$ long; spurs of middle tibia 13-14 $\mu \mathrm{m}$ long and $14 \mu \mathrm{m}$ (1), of hind tibia 20 and $22 \mu \mathrm{m}$ long, all excluding comb. Length of front femur 804-911 $\mu \mathrm{m}$, of front tibia 424-468 $\mu \mathrm{m}$, all tarsi lacking.

Hypopygium (figs. 10-13). Laterosternite IX with 2 setae Phallapodeme $82-110 \mu \mathrm{m}$ long, transverse sternapodeme 60-66 $\mu \mathrm{m}$ long. Superior volsella (fig. 12) somewhat rectangular with posterior margin produced; median volsella (fig. 13) 62-66 $\mu \mathrm{m}$ long, slightly $\mathrm{S}$-shaped, with distal lamelliform setae fused into single plate without apical points. Inferior volsella with microtrichia, superior and median volsellae without microtrichia.

Distribution. - The species is known only from the West Usumbara Mountains in Tanzania, where it was taken along a stream.

\section{Rheotanytarsus plerunguis sp. $\mathrm{n}$.}

(figs. 14-17)

Type locality. - TANZANIA: Tanga Region, West Usambara Mts, Mazumbai.

Type material. - Holotype $\hat{\sigma}$, TANZANIA: Tanga Region, West Usambara Mts, Mazumbai, 28 x 1990, light trap, ZMBN's Tanzania expedition (ZMBN Type No. 314). Paratype: $1 \delta^{\hat{\sigma}}$, as holotype.

Diagnostic characters. - See key.

Etymology. - From the Latin plerus, very many and unguis, claws; referring to the many curved clawlike setae on the median volsella.

\section{Male imago $(\mathrm{n}=1-2)$}

Total length $3.00 \mathrm{~mm}$. Wing length 1.91-1.95 $\mathrm{mm}$. Total length / wing length 1.53. Wing length / length of profemur 2.23-2.27. Thorax and abdomen pale, legs pale with forelegs darker.

Head. AR 0.85-0.87. Thirteenth flagellomere 443$468 \mu \mathrm{m}$ long. Temporal setae 9, including 4 inner verticals, 2 outer verticals, and 3 postorbitals. Clypeus with 13-14 setae. Tentorium 84-121 $\mu \mathrm{m}$ long, $32 \mu \mathrm{m}$ wide at sieve pore and $18 \mu \mathrm{m}$ wide at posterior tento- rial pit. Stipes 132-150 $\mu \mathrm{m}$ long, 7-14 $\mu \mathrm{m}$ wide. Lengths of palpomere 1 to 4 (in $\mu \mathrm{m}$ ): 32-36, 39, 139143, 132; segment 5 lacking.

Thorax. Dorsocentrals 8-9, acrostichals 22-24. Scutellum with 5 setae.

Wing. VR 1.31-1.33. R with 26 setae, R1 with 3942, R4+5 with 77-78 setae, Sc, RM and M bare; $\mathrm{M} 1+2$ with $87-80, \mathrm{M} 3+4$ with $43-52, \mathrm{Cu}$ with 2129, Cu1 with 26-27, PCu with 61 and An with 41-46 setae. Cells $m$ with 29-34 setae, $\mathrm{r} 4+5$ with about 350 , $\mathrm{m} 1+2$ with about $300, \mathrm{~m} 3+4$ with about 200 , cu with about 200 and an with 77-85 setae.

Legs. Spur of front tibia 27-35 $\mu \mathrm{m}$ long, spurs of middle tibia 13 and 15-18 $\mu \mathrm{m}$ long, of hind tibia 1320 and $20 \mu \mathrm{m}$ long, all excluding comb. Comb of middle tibia 13-15 $\mu \mathrm{m}$ long, of hind tibia 15-18 $\mu \mathrm{m}$ long. Width at apex of front tibia 49-51 $\mu \mathrm{m}$, of middle tibia $42-44 \mu \mathrm{m}$, of hind tibia $49 \mu \mathrm{m}$. Lengths and proportions of legs see table 2 .

Hypopygium (figs. 14-17). Tergite IX with 10-12 setae. Anal point 60-67 $\mu \mathrm{m}$ long, 24-31 $\mu \mathrm{m}$ wide at base; $9-11 \mu \mathrm{m}$ wide at apex; crest rounded and basally closed. Laterosternite IX with 1 seta. Phallapodeme 67-69 $\mu \mathrm{m}$ long, transverse sternapodeme 40-44 $\mu \mathrm{m}$ long. Gonocoxite 104-118 $\mu \mathrm{m}$ long, gonostylus 95$113 \mu \mathrm{m}$ long. Superior volsella (fig. 16) 33-38 $\mu \mathrm{m}$ long, oblong; inferior volsella $67-75 \mu \mathrm{m}$ long; median volsella (fig. 17) 60-67 um long, strongly S-shaped, with several foliate lamellae or setae and distal lamellae fused into single plate with terminal points. Inferior volsella with microtrichia, superior and median volsellae without microtrichia. HR 1.04-1.09, HV 2.65.

Distribution. - The species is known only from a rain forest area in the West Usambara Mts in NE Tanzania.

\section{The photophilus group}

The pupa of this group is characterised by having a thoracic horn with median bend and points in apical half, tergites II-V with circular anterior spine patches, posterior shagreen patch on tergite II not divided, 
Table 3. Rheotanytarsus angustus, male. Lengths (in $\mu \mathrm{m}$ ) and proportions of legs.

\begin{tabular}{ccccccc} 
& $\mathrm{fe}$ & $\mathrm{ti}$ & $\mathrm{ta}_{1}$ & $\mathrm{ta}_{2}$ & $\mathrm{ta}_{3}$ & $\mathrm{ta}_{4}$ \\
\hline $\mathrm{p}_{1}$ & $608-820(3)$ & $304-380(3)$ & - & - & - & - \\
$\mathrm{p}_{2}$ & $576-848,717$ & $408-692,552$ & $280-372$ & $120-196$ & $80-140$ & $48-88$ \\
$\mathrm{p}_{3}$ & $632-960,800$ & $520-860,683$ & $546(1)$ & $343(1)$ & $264(1)$ & $175(1)$ \\
\hline & $\mathrm{ta}_{5}$ & $\mathrm{LR}$ & $\mathrm{BV}$ & $\mathrm{SV}$ & $\mathrm{BR}$ \\
\hline $\mathrm{p}_{1}$ & - & - & - & - & - \\
$\mathrm{p}_{2}$ & $40-61(2)$ & $0.54-0.60$ & $4.01-4.67(2)$ & $3.80-4.14$ & - \\
$\mathrm{p}_{3}$ & $93(1)$ & $0.69(1)$ & $2.54(1)$ & $3.10(1)$ & $5.2(1)$ & \\
\hline
\end{tabular}

and anal lobe without dorsal seta.

The male imagines have basal tergite bands and strongly developed V-shaped bands; anal point with $\mathrm{V}$ - shaped to short rounded crest; superior volsella with posterior extension; median volsella not reaching apex of superior volsella, with apical setae usually fused into plate with points, and gonostylus abruptly tapered in apical portion.

\section{Rheotanytarsus angustus (Freeman) comb. $\mathrm{n}$. (figs. 22-30)}

Tanytarsus (Tanytarsus) angustus Freeman, 1955: 35; 1958: 335.

Material examined. - D. R. CONGO: Parc National Albert, Riv. Bishakishaki, $2100 \mathrm{~m}$ a.s.l., holotype $\delta$, $2+$ paratypes, 22 iv 1934, G. F. de Witte: 347. TANZANIA: Arusha Region, Arusha, Mt. Mehru Hotel, ô 8 xii 1990, sweep net, ZMBN's Tanzania expedition (ZMBN). SOUTH AFRICA: Kruger National Park, 2 ô, 2 v 1991, UV - light trap, I. Pajor (ZSM); Natal Province, Merrivale, 2931'S 30¹5'E, 9-13 x 1990, B.R. Stuckenberg.

Diagnostic characters. - See keys.

Male imago ( $n=4-5$ except when otherwise stated)

Total length 2.46-3.07, $2.76 \mathrm{~mm}$. Wing length 1.24-1.86, $1.66 \mathrm{~mm}$. Total length / wing length 1.65-2.00, 1.85. Wing length / length of profemur 1.98-2.04 (3). Thorax pale with slight tinge of brown vittae and postnotum, abdomen pale, legs pale.

Head. AR 0.67-0.83, 0.74. Thirteenth flagellomere 310-488, $372 \mu \mathrm{m}$ long. Temporal setae 7-9 (3); including 3-4 (3) inner verticals; 2-3 (3) outer verticals; and 2-3 (3) postorbitals. Clypeus with 12-20 (3) setae. Tentorium 100-126, $117 \mu \mathrm{m}$ long; 26-40, $34 \mu \mathrm{m}$ wide at sieve pore and $12-18,14 \mu \mathrm{m}$ wide at posterior tentorial pit. Stipes 100-132, $144 \mu \mathrm{m}$ long; 18-30, $22 \mu \mathrm{m}$ wide. Palpomere lengths (in $\mu \mathrm{m}$ ): 29-38, 33; $32-38,32 ; 104-134,123 ; 110-125,116 ; 222-234$ (3). Fifth palpomere / third palpomere 1.66-1.93 (3).

Thorax. Dorsocentrals 8-13, 10; acrostichals 1822, 20. Scutellum with 3-7, 5 setae.

Wing. VR 1.31-1.48, 1.43. R with 20-25, 23 setae;
R1 with 27-47, 36; R4+5 with 53-85, 64 setae; Sc and $M$ bare; RM with $0-2$, 1 setae; $M 1+2$ with $55-98$, 71; M3+4 with 34-42, 38 setae; $\mathrm{Cu}$ with 15-23, 19; Cul with 18-28, 23; PCu with 52-83, 60; and An with 34-41, 36 setae. Cells $m$ with 29 setae, $r 4+5$ with about $300, \mathrm{~m} 1+2$ with about $300, \mathrm{~m} 3+4$ with 145 , cu with 114 and an with 55 setae.

Legs. Spur of front leg 16-18 (3) $\mu \mathrm{m}$ long. Spurs of middle tibia 6-14, 8 and 12-16, $13 \mu \mathrm{m}$ long; spurs of hind tibia 10-15, 12 and 14-20, $17 \mu \mathrm{m}$ long; all excluding comb. Comb of middle tibia 10-16, $13 \mu \mathrm{m}$ long; of hind tibia 12-20, $15 \mu \mathrm{m}$ long. Width at apex of fore tibia 34-44 (3) $\mu \mathrm{m}$, middle tibia 32-42, 37 $\mu \mathrm{m}$; of hind tibia 38-49, $44 \mu \mathrm{m}$. Lengths and proportions of legs see table 3 .

Hypopygium (figs. 22-25). Tergite IX with 8-14, 11 setae. Anal point 52-76, $66 \mu \mathrm{m}$ long; 18-27, $24 \mu \mathrm{m}$ wide at base; 8-11, 9 mm wide at apex; crest V-shaped and open. Laterosternite IX with 1 seta. Phallapodeme 68-98, $77 \mu \mathrm{m}$ long; transverse sternapodeme 44-50, $47 \mu \mathrm{m}$ long. Gonocoxite 104-122, $113 \mu \mathrm{m}$ long; gonostylus 96-114, $105 \mu \mathrm{m}$ long. Superior volsella (fig. 24) 30-38, $34 \mu \mathrm{m}$ long, somewhat triangular; inferior volsella 66-86, $74 \mu \mathrm{m}$ long; median volsella (fig. 25) 52-78, $65 \mu \mathrm{m}$ long, not markedly recurved, with several short ovoid distal plates without apical points. Inferior volsella with microtrichia, superior and median volsellae without microtrichia. HR 1.04-1.12, 1.07; HV 2.56-2.87, 2.69.

\section{Female $(\mathrm{n}=1-2)$}

Total length 2.18-2.24 mm. Wing length $1.86 \mathrm{~mm}$. Total length / wing length 1.20. Wing length / length of profemur 1.20. Thorax, legs and abdomen pale.

Head. AR 0.25-0.28. Lengths of flagellomeres (in $\mu \mathrm{m}):$ 84-90, 60-68, 68-78, 56-66, 76. Temporal setae 7-8 in single row, including 3-4 inner verticals, 2-3 outer verticals, and 1-2 postorbitals. Clypeus with $17-$ 18 setae. Tentorium 104-110 $\mu \mathrm{m}$ long, 14-16 $\mu \mathrm{m}$ wide at sieve pore and 8-10 $\mu \mathrm{m}$ wide at posterior tentorial pit. Stipes $120 \mu \mathrm{m}$ long, 26-36 $\mu \mathrm{m}$ wide. Lengths of palpomeres (in $\mu \mathrm{m}$ ): 34-36, 32-36, 132, 110-124, 214-220. Fifth palpomere/ third palpomere 
Table 4. Rheotanytarsus angustus, female. Lengths (in $\mu \mathrm{m}$ ) and proportions of legs.

\begin{tabular}{|c|c|c|c|c|c|c|c|c|c|c|c|}
\hline & $\mathrm{fe}$ & $\mathrm{ti}$ & $\mathrm{ta}_{1}$ & $\mathrm{ta}_{2}$ & $\mathrm{ta}_{3}$ & $\mathrm{ta}_{4}$ & $\mathrm{ta}_{5}$ & LR & BV & SV & $\mathrm{BR}$ \\
\hline $\mathrm{p}_{1}$ & 860 & 500 & - & - & - & - & - & - & - & - & - \\
\hline $\mathrm{p}_{2}$ & 800 & $640-680$ & - & - & - & - & - & - & - & - & - \\
\hline $\mathrm{p}_{3}$ & $864-880$ & $784-820$ & 520 & 320 & 260 & 152 & 88 & 0.66 & 2.64 & 3.17 & 5.1 \\
\hline
\end{tabular}

\section{$1.62-1.67$}

Thorax. Dorsocentrals 12-13, acrostichals 16 . Scutellum with 3-4 setae.

Wing setae not countable.

Legs. Spur of front tibia $20 \mu \mathrm{m}$ long, spurs of middle tibia 12-14 and 16-20 $\mu \mathrm{m}$ long, of hind tibia 18 and $22 \mu \mathrm{m}$ long, all excluding comb. Combs 14-16 $\mathrm{mm}$ long. Width at apex of front tibia $46 \mu \mathrm{m}$, of middle tibia 40-46 $\mu \mathrm{m}$ long. of hind tibia 50-56 $\mu \mathrm{m}$. Lengths (in $\mu \mathrm{m}$ ) and proportions of legs see table 4 .

Abdomen. Number of setae on tergites and sternites not countable.

Genitalia (figs. 26-30). Gonocoxite without setae. Tergite IX with 26 setae. Cercus 62-68 $\mu \mathrm{m}$ long, 6-8 $\mu \mathrm{m}$ wide at apex. Seminal 60-66 $\mu \mathrm{m}$ long including 10-12 $\mu \mathrm{m}$ long neck. Notum 158-166 $\mu \mathrm{m}$ long.

Distribution. - The species is known from a small rapid river with stones and gravel at the foothills of Mt. Mehru in northern Tanzania and from the Kruger National Park in South Africa.

\section{Rheotanytarsus remus $\mathrm{sp} . \mathrm{n}$. (figs. 18-21)}

Type locality. - GHANA: Eastern Region, Kibi, Subri River.

Type material. - Holotype $\widehat{\sigma}$, GHANA: Eastern Region, Kibi, Subri River, 6 xi 1993, light trap, NUFU project (ZMBN Type No. 315).

Diagnostic characters. - See key.

Etymology. - After the Latin remus meaning oar, referring to the shape of the median volsella.

\section{Male imago $(n=1)$}

All measurements and shapes within the range of $R$. angustus (Freeman) described below, with the following exceptions and additions:

Wing length / length of profemur 1.73. Thorax and abdomen pale, legs pale with apical $1 / 4$ darker.

Head. Antennae lacking. Palpomere lengths (in $\mu \mathrm{m}):$ 22, 33, 98, 93, 189.

Wing. Sc with 22 setae, M3+4 with 31, setae. Cells m with 26 setae, cu with 70 , and an with 73 setae.

Legs. Spur of front tibia $29 \mu \mathrm{m}$ long; spurs of middle tibia broken, of hind tibia 20 and $29 \mu \mathrm{m}$ long, all excluding comb. Combs 15-18 $\mu \mathrm{m}$ long. Width at apex of front tibia $42 \mu \mathrm{m}$, of middle tibia $33 \mu \mathrm{m}$, of hind tibia $44 \mu \mathrm{m}$. Tarsi of front and hind legs lost.

Hypopygium (figs.18-21). Tergite IX with 16 setae. Laterosternite IX with 2 setae. Transverse sternapodeme $58 \mu \mathrm{m}$ long. Superior volsella (fig. 20) 27 $\mu \mathrm{m}$ long, triangular to rectangular; inferior volsella 60 $\mu \mathrm{m}$ long; median volsella (fig. 21) $71 \mu \mathrm{m}$ long, not markedly curved, with several short ovoid distal plates without apical points. Inferior volsella with microtrichia, superior and median volsellae without microtrichia. HR 1.02 .

Distribution. - The species is known only from a small river in southern Ghana.

\section{The globosus group}

The pupa of $R$. globosus has thoracic horn with median bend and spinules in apical half; tergites II-V with circular anterior patches of spinules; tergite II with undivided posterior shagreen; caudal hooklets of tergite II occupying median $1 / 3-1 / 2$; and hair-like dorsal anal lobe seta.

The imagines have 1-3 setae between V-shaped anal tergite bands; not spatulate anal point with $\mathrm{V}$ shaped open crest; digitus sometimes extending beyond margin of rounded superior volsella; median volsella extending beyond superior volsella, but not reaching apex of inferior volsella.

$R$. longicornus is tentatively placed in the group.

\section{Rheotanytarsus bufemoratus sp. $\mathrm{n}$.}

(figs. 31-34)

Tanytarsus (Rheotanytarsus) fuscus Freeman, 1954: 25, pro parte

Rheotanytarsus fuscus (Freeman), Freeman \& Cranston 1980: 200, pro parte

Type locality. - UGANDA: Mt. Elgon, Bulambuli.

Type material. - Holotype ơ, UGANDA: Mt. Elgon, Bulambuli, 9.500 ft., 8 viii 1934, J. Ford (B. M. 1935-459) (BMNH).

Diagnostic characters. - See key.

Etymology. - After the Latin femoris meaning thigh and the prefix-bu meaning large, and the suffix -atus denoting the gender of the genus; referring to the large thigh-like gonostylus. 

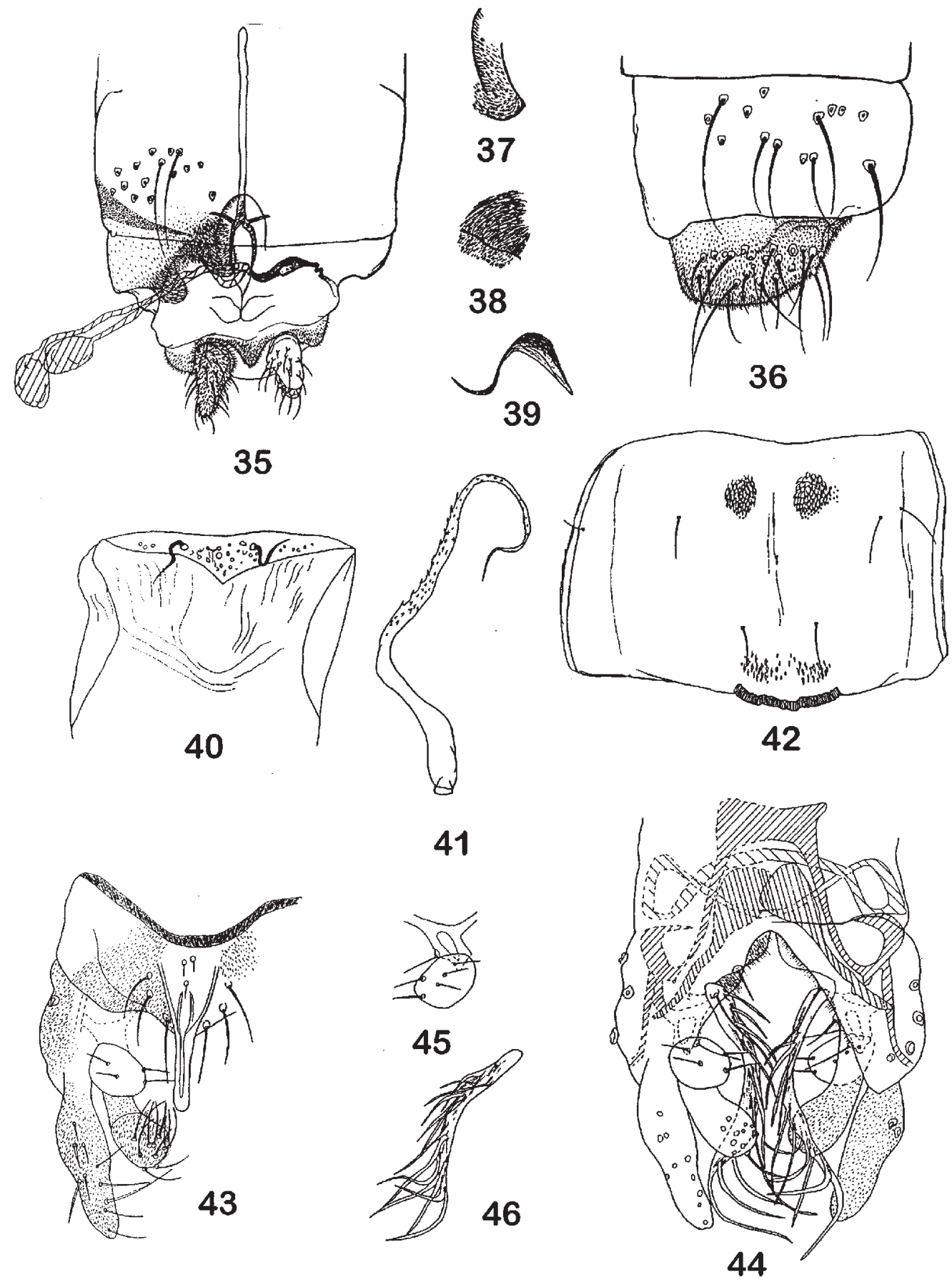

Figs. 35-42. Rheotanytarsus longicornus sp. n., female imago and pupa. - 35, 36, genitalia, ventral and dorsal view; 37, dorsomesal lobe; 38, ventrolateral lobe; 39, apodeme lobe; 40, frontal apotome of pupa, 41, thoracic horn; 42 , tergite II. - figs. 43-46. $R$. buculicaudus Kyerematen, male imago. - 43, 44, hypopygium, dorsal and ventral view; 45, superior volsella; 46, median volsella. 
Table 5. Rheotanytarsus bufemoratus, male. Lengths (in $\mu \mathrm{m}$ ) and proportions of legs.

\begin{tabular}{|c|c|c|c|c|c|c|c|c|c|c|c|}
\hline & fe & $\mathrm{ti}$ & $\mathrm{ta}_{1}$ & $\mathrm{ta}_{2}$ & $\mathrm{ta}_{3}$ & $\mathrm{ta}_{4}$ & $\mathrm{ta}_{5}$ & LR & BV & SV & $\mathrm{BR}$ \\
\hline $\mathrm{p}_{1}$ & 893 & 600 & 1000 & 535 & 339 & 293 & 107 & 1.67 & 1.93 & 1.49 & 4.1 \\
\hline $\mathrm{p}_{2}$ & 839 & 671 & 393 & 203 & 143 & 82 & - & 0.58 & - & 3.84 & 6.1 \\
\hline $\mathrm{p}_{3}$ & 989 & 911 & 589 & 357 & 286 & 178 & 93 & 0.65 & 2.72 & 3.22 & 5.9 \\
\hline
\end{tabular}

\section{Male imago $(\mathrm{n}=1)$}

Total length $3.15 \mathrm{~mm}$. Wing length $2.22 \mathrm{~mm}$. Total length / wing length 1.42. Wing length / length of profemur 2.65. Completely dark brown.

Head. AR 0.59. Thirteenth flagellomere $375 \mu \mathrm{m}$ long. Temporal setae 7 , including 3 inner verticals, 2 outer verticals, and 2 postorbitals. Clypeus with 15 setae. Tentorium $102 \mu \mathrm{m}$ long, $31 \mu \mathrm{m}$ wide at sieve pore and $11 \mathrm{~mm}$ wide at posterior tentorial pit. Stipes $109 \mu \mathrm{m}$ long, $22 \mu \mathrm{m}$ wide. Length of palpomere 1 to 4 (in $\mu \mathrm{m}$ ): 38, 35, 129, 104; palpomere 5 lacking.

Thorax. Dorsocentrals 7, acrostichals 18. Scutellum with 5 setae.

Wing. VR 1.45. R with 21 setae, R1 with 40, R4+5 with 70 , Sc and M bare; RM with $1 ; \mathrm{M} 1+2$ with 83 , $\mathrm{M} 3+4$ with $44, \mathrm{Cu}$ with 22 , Cu1 with $27, \mathrm{PCu}$ with 57 and An with 38 setae. Cells m with 17 setae, $\mathrm{r} 4+5$ with about $400, \mathrm{~m} 1+2$ with about $350, \mathrm{~m} 3+4$ with 120 , cu with 87 and an with 30 .

Legs. Spur of front tibia $27 \mu \mathrm{m}$ long, spurs of middle tibia $11 \mu \mathrm{m}$ long and the other lacking, of hind tibia 9 and $15 \mu \mathrm{m}$ long, all excluding comb. Combs 11-13 $\mu \mathrm{m}$ long. Width at apex of front tibia $47 \mu \mathrm{m}$, of middle tibia $44 \mu \mathrm{m}$, of hind tibia $51 \mu \mathrm{m}$. Lengths and proportions of legs see table 5.

Hypopygium (figs. 31-34). Tergite IX with 10 setae. Anal point $71 \mu \mathrm{m}$ long, $18 \mu \mathrm{m}$ wide at base, 11 $\mu \mathrm{m}$ wide at apex, crest V-shaped and basally open. Laterosternite IX with 2 setae. Phallapodeme $95 \mu \mathrm{m}$ long, transverse sternapodeme $49 \mu \mathrm{m}$ long. Gonocoxite $129 \mu \mathrm{m}$ long, gonostylus $124 \mu \mathrm{m}$ long. Superior volsella (fig. 33) $40 \mu \mathrm{m}$ long, rectangular; inferior volsella $84 \mu \mathrm{m}$ long; median volsella (fig. 34) $78 \mu \mathrm{m}$ long, slightly S-shaped, with lamelliform setae fused into plate without apical points. Inferior volsella with microtrichia, superior and median volsellae without microtrichia. HR 1.04; HV 2.54.

Distribution. - The species is known only from the type locality on Mt Elgon.

\section{Rheotanytarsus longicornus sp. n.} (figs. 35-42)

Type locality. - SOUTH AFRICA: East Rand.

Type material. - Holotype mature $q$ pupa, SOUTH AFRICA: East Rand, stream, 24 vii 1989, drift, P. Scotney (ZMBN Type No. 316). Paratype: 1 mature $q$ pupa as holotype (PLH).

Diagnostic characters. - See keys.

Etymology. - From the Latin longus, long, and cornus, horn, referring to the extremely long thoracic horn of the pupa.

\section{Female $(\mathrm{n}=1-2)$}

Total length $2.92-2.98 \mathrm{~mm}$. Thorax with dark vittae, postnotum and pre-episternum. Legs and abdomen pale.

Head. AR 0.33-0.35. Lengths of flagellomeres (in $\mu \mathrm{m})$ : 64-70, 40-46, 50-56,48-54, 70-74. Temporal setae 8 , including 4 inner verticals, 2 outer verticals, and 2 postorbitals. Tentorium $104 \mu \mathrm{m}$ long, $24 \mu \mathrm{m}$ wide at sieve pore, $8 \mathrm{~mm}$ wide at posterior tentorial pit. Stipes $70 \mu \mathrm{m}$ long, $20 \mu \mathrm{m}$ wide. Palpomere lengths (in $\mu \mathrm{m}$ ): 26-32, 26-28, 60-80, 80, 120-130. Fifth palpomere / third palpomere 1.62-2.00.

Thorax. Dorsocentrals 16-19, acrostichals 20-22. Scutellum with 5-7 setae.

Wing setae not countable.

Legs. Spur of front tibia $18 \mu \mathrm{m}$ long, spurs of middle tibia 10 and $12 \mu \mathrm{m}$ long, of hind tibia 10 and 16 $\mu \mathrm{m}$ long, all excluding comb. Combs 12-14 $\mu \mathrm{m}$ long. Width at apex of front tibia $44 \mu \mathrm{m}$, of middle tibia 44 $\mu \mathrm{m}$, of hind tibia $52 \mu \mathrm{m}$. Lengths and proportions of legs see table 6 .

Abdomen. Number of setae on tergites and sternites could not be counted due to folding of tergites.

Genitalia (figs. 35-39). Gonocoxite without setae. Tergite IX with 40-50 setae. Cercus 50-60 $\mu \mathrm{m}$ long, 6-16 $\mu \mathrm{m}$ wide at apex. Seminal capsule 56-60 $\mu \mathrm{m}$

Table 6. Rheotanytarsus longicornis, female. Lengths (in $\mu \mathrm{m}$ ) and proportions of legs.

\begin{tabular}{cccccccccc} 
& $\mathrm{fe}$ & $\mathrm{ti}$ & $\mathrm{ta}_{1}$ & $\mathrm{ta}_{2}$ & $\mathrm{ta}_{3}$ & $\mathrm{ta}_{4}$ & $\mathrm{ta}_{5}$ & $\mathrm{LR}$ & $\mathrm{BV}$ \\
\hline $\mathrm{p}_{1}$ & 496 & 320 & 600 & 336 & 232 & 200 & 104 & 1.87 & 1.62 \\
$\mathrm{p}_{2}$ & - & - & 280 & 128 & 88 & 48 & 40 & - & - \\
$\mathrm{p}_{3}$ & - & - & 240 & 208 & 160 & 120 & 80 & - & - \\
\hline
\end{tabular}



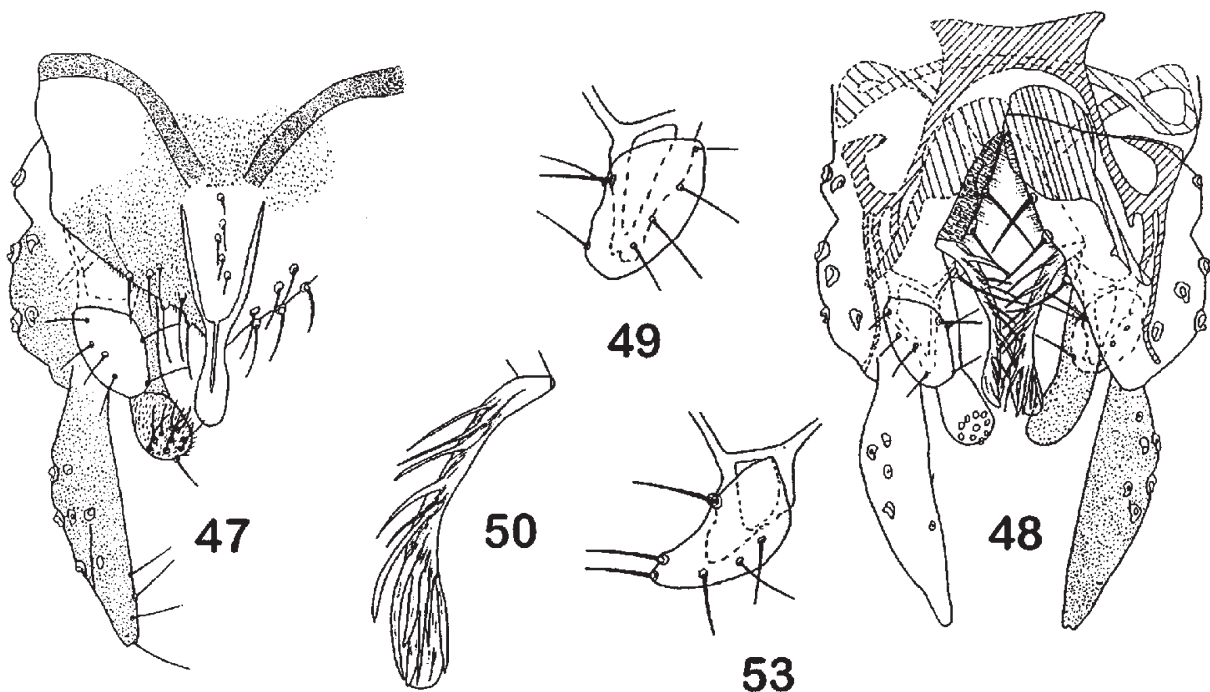

53
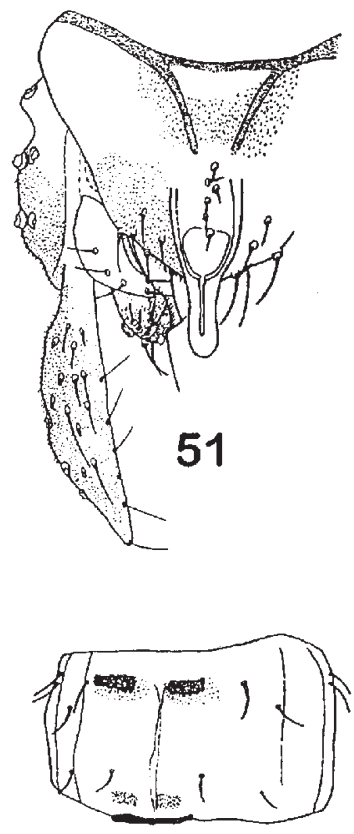

55
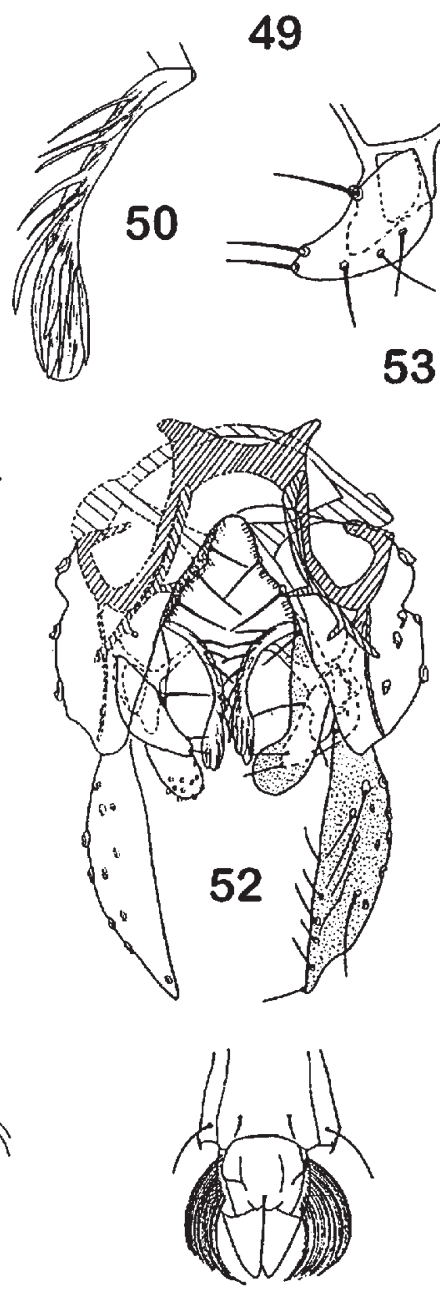

56

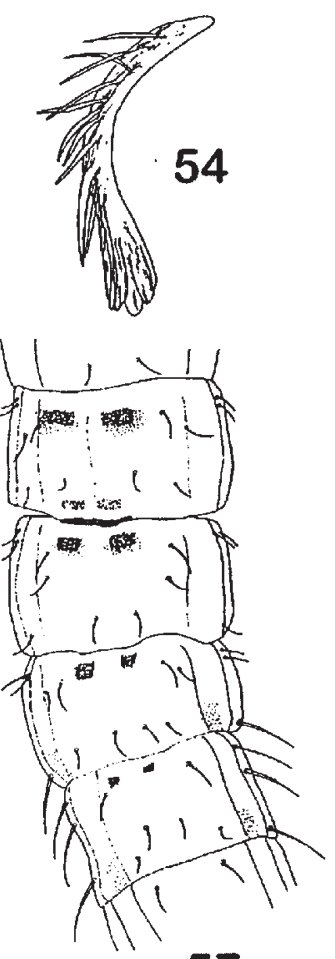

57

Figs. 47-50. Rheotanytarsus abonae sp. n., male imago. - 47, 48, hypopygium, dorsal and ventral view; 49, superior volsella; 50, median volsella. - figs. 51-57. R. fuscus (Freeman), male imago and pupa. - 51, 52, hypopygium, dorsal and ventral view; 53, superior volsella; 54, median volsella; 55, pupal tergite II; 56, anal lobe; 57, tergites II-V. 
long including 6-12 $\mu \mathrm{m}$ long neck, 40-62 $\mu \mathrm{m}$ wide; not sclerotized. Notum 156-170 $\mu \mathrm{m}$ long.

\section{Pupa $(\mathrm{n}=1-2)$}

Total length 3.52-3.84 mm. Exuviae pale with outer edges of cephalothorax dark.

Cephalothorax. Frontal apotome (fig. 40) slightly granulose anteriorly. Frontal setae $28 \mu \mathrm{m}$ long. Thoracic horn (fig. 41) 630-720 $\mu \mathrm{m}$ long; 40-52 $\mu \mathrm{m}$ wide; with fine spinules on the second half of its length. Median antepronotals 160-228 $\mu \mathrm{m}$ long; lateral antepronotals $32 \mu \mathrm{m}$ long; both median and lateral antepronotals taeniate. Precorneals close together; anterior precorneals $48 \mu \mathrm{m}$ long, taeniate; median precorneals $100-140 \mu \mathrm{m}$ long; posterior precorneals 220$230 \mu \mathrm{m}$ long, both taeniate. Anterior dorsocentrals not observable. Nose of wing sheath 24-26 $\mu \mathrm{m}$ long.

Abdomen. Tergite I bare; spines on tergites II-V arranged in circular patches. Tergite II (fig. 42) with additional pair of posterior patches of very fine spinules. Median shagreen essentially absent, weak and sparse shagreen present caudolaterally on tergites IV and V. Number of spines on T II-V 50-60, 50-60, 3035,20 . Caudal hooklets occupying approximately median $1 / 2$ of tergite II, about 75-80 hooklets. Caudal spur $10 \mu \mathrm{m}$ long. L-setae on segments II-VIII as 2, 2, 3, 3, 4, 4, 4; those on II and III hairlike, those on IV 2 hairlike 1 taeniate and those on VI-VIII all taeniate 2126 taeniae in fringe; longest taeniae 300-340 $\mu \mathrm{m}$ long.

Distribution. - The species is known only from a stream in East Rand, South Africa.

\section{The pellucidus group}

The pupae of the group have the unique synapomorphy of having the anterior spine patches restricted to tergites II-IV. The frontal apotome is rugulose, at least anteriorly; the thoracic horn has a median bend in the pellucidus agglomerate, but not in the more basal species and there are spinule points at least in apical half; the posterior shagreen of tergite II is arranged as two groups of spinule patches; the caudal hooklets of tergite II usually occupies less than median third and always less than median half; the caudolateral spur on segment $\mathrm{V}$ usually has several teeth; and there is usually a hair-like dorsal anal lobe seta.

Most males have a long median volsella extending at least to the apex of the inferior volsella and without any apical plate. The anal point is usually narrow or tapering, but may be relatively broad, or occasionally spatulate. The superior volsella is usually rounded. The gonostylus is not abruptly tapered except in some basal species.

\section{Rheotanytarsus buculicaudus Kyerematen}

(figs. 43-46)

Rheotanytarsus buculicaudus Kyerematen in Kyerematen, Sæther \& Andersen (2000).

Diagnostic characters. - See key.

The species is shown in fig. 43-46. A full description is given in Kyerematen, Sæther \& Andersen (2000).

\section{The guineensis group}

The pupae of the guineensis group have at least tergites II with the spine patches rectangular or transversely elongate instead of rounded. The frontal apotome of the group usually is smooth. The thoracic horn is bare or with spines in apical $1 / 4-1 / 2$. There are spine patches on tergites II-V or usually on II-VI. Many species lack a dorsal seta on the anal lobe, but when it is present it is hair-like.

In the males the posterior margin of tergite VIII occasionally is straight, a feature otherwise present only in the trivittatus group. The digitus extends beyond the margin of the superior volsella in a few species. In most species of the guineensis s. str. group the superior volsella has posterior margin hook- or knob-like, while in the remaining species the superior volsella is rounded. The median volsella does not reach the apex of the inferior volsella and often neither the apex of the superior volsella.

\section{Rheotanytarsus abonae Kyerematen sp. $\mathbf{n}$.}

(figs. 47-50)

Type locality. - TANZANIA: Tanga Region, W. Usambara Mts., Mazumbai, Kaputu Stream.

Type material. - Holotype $\widehat{\delta}$, TANZANIA: Tanga Region, W. Usambara Mts., Mazumbai, Kaputu Stream, loc. 10, 1420 m a.s.l., xi 1990, Malaise trap, ZMBN's Tanzania expedition (ZMBN Type No. 317).

Diagnostic characters. - See key.

Etymology. - Named after the mother of the first author, Abon Brentuo - Lartey.

\section{Male imago $(\mathrm{n}=1)$}

Total length $2.03 \mathrm{~mm}$. Wing length $1.25 \mathrm{~mm}$. Total length / wing length 1.63. Wing length / length of profemur 2.06. Thorax, abdomen and legs pale.

Head. AR 0.23. Thirteenth flagellomere $118 \mu \mathrm{m}$ long. Temporal setae 7 , including 3 inner verticals, 2 outer verticals, and 2 postorbitals. Clypeus with 16 setae. Tentorium $49 \mu \mathrm{m}$ long, $15 \mu \mathrm{m}$ wide at sieve pore, $9 \mathrm{~mm}$ wide at posterior tentorial pit.

Stipes $78 \mu \mathrm{m}$ long, $7 \mu \mathrm{m}$ wide. Lengths of palpomere 1 and 2 (in $\mu \mathrm{m}$ ): 27, 33; segments 3 to 5 lacking.

Thorax. Dorsocentrals 10, acrostichals 18. Scutel- 

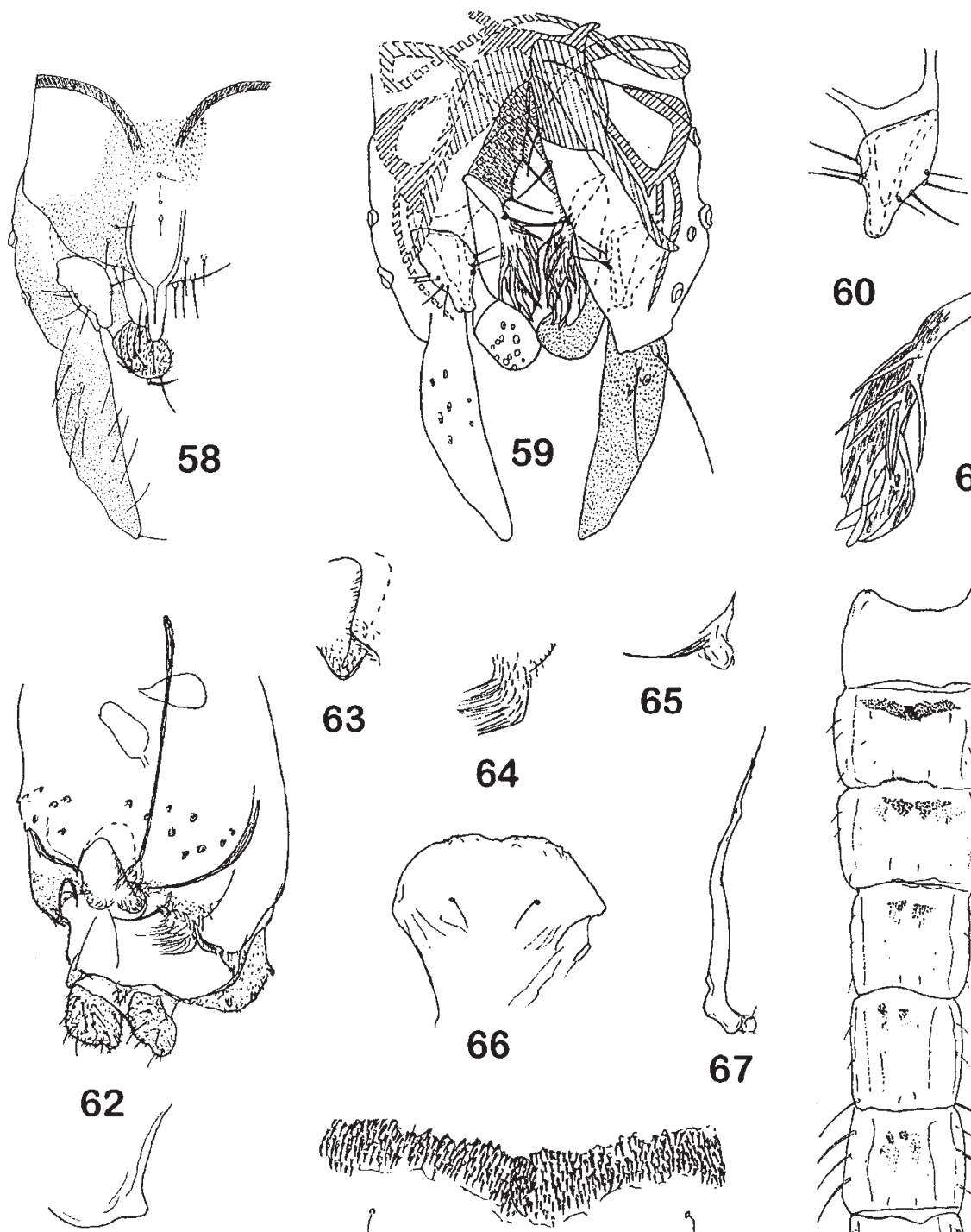

68
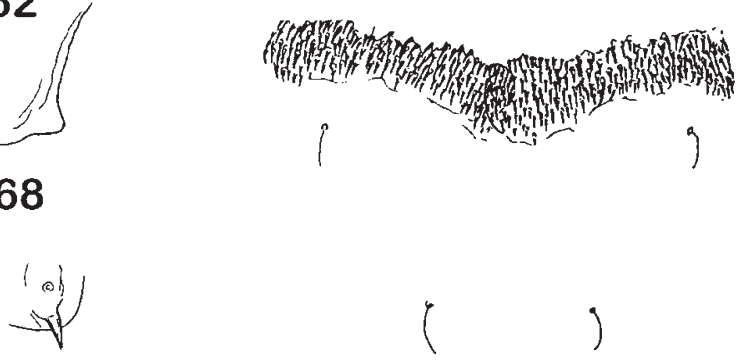

71

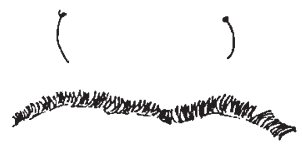

70

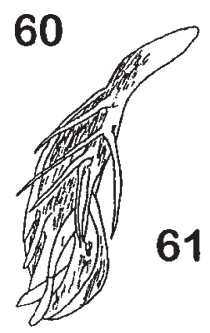

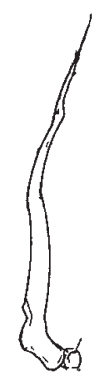

67

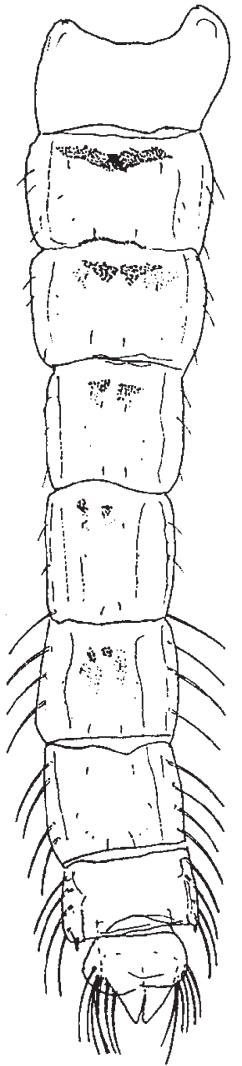

69

Figs. 58-61. Rheotanytarsus montanus Lehmann, male imago. - 58, 59, hypopygium, dorsal and ventral view; 60, superior volsella; 61, median volsella. - figs. 62-71. R. transversus sp. n., female imago and pupa. - 62, genitalia, ventral view; 63, dorsomesal lobe; 64, ventrolateral lobe; 65, apodeme lobe; 66, frontal apotome of pupa; 67 , thoracic horn; 68, wing sheath nose; 69, caudal spur; 70, tergite II; 71, tergites I-IX. 
Table 7. Rheotanytarsus fuscus, male. Lengths (in $\mu \mathrm{m}$ ) and proportions of legs.

\begin{tabular}{|c|c|c|c|c|c|c|}
\hline & $\mathrm{fe}$ & ti & $\mathrm{ta}_{1}$ & $\mathrm{ta}_{2}$ & $\mathrm{ta}_{3}$ & $\mathrm{ta}_{4}$ \\
\hline $\mathrm{p}_{1}$ & 589-678 & $336-375$ & $664-821$ & $393-439$ & $268-303$ & 211-243 \\
\hline $\mathrm{p}_{2}$ & $578-721$ & $464-578$ & $271-328$ & $136-161$ & $96-114$ & $71-75$ \\
\hline \multirow[t]{2}{*}{$\mathrm{p}_{3}$} & $643-786$ & $571-714$ & $357-446$ & $253-286$ & $200-232$ & $139-168$ \\
\hline & ta5 & LR & BV & SV & BR & \\
\hline $\mathrm{p}_{1}$ & $86-104$ & $1.99-2.20$ & $1.65-1.74$ & $1.28-1.39$ & $3.0-3.3$ & \\
\hline $\mathrm{p}_{2}$ & $54-57$ & $0.57-0.59$ & 3.77 & $3.79-3.96$ & $4.6-5.0$ & \\
\hline $\mathrm{p}_{3}$ & $68-86$ & $0.62-0.65$ & $2.39-2.57$ & $3.30-3.40$ & $5.5-6.3$ & \\
\hline
\end{tabular}

lum with 4 setae.

Wing. VR 1.72. R with 15 setae, $\mathrm{R} 1$ with $28, \mathrm{R} 4+5$ with 63 , Sc and $M$ bare, RM with $1, M 1+2$ with 53, M3+4 with 30, Cu with 18 , Cul with $16, \mathrm{PCu}$ with 47, and An with 25 setae. Cells m with 17 setae, $r 4+5$ with about $350, \mathrm{~m} 1+2$ with about $300, \mathrm{~m} 3+4$ with about 150 , cu with 98, and an with 52 setae.

Legs. Spur of front tibia $22 \mu \mathrm{m}$ long, spurs of middle tibia 7 and $13 \mu \mathrm{m}$ long, of hind tibia 13 and 15 $\mu \mathrm{m}$ long, all excluding comb. Combs 11-13 $\mu \mathrm{m}$ long. Width at apex of front tibia $38 \mu \mathrm{m}$, of middle tibia 31 $\mu \mathrm{m}$, of hind tibia $35 \mu \mathrm{m}$. Length of front femur 607 $\mu \mathrm{m}$, of middle femur $589 \mu \mathrm{m}$, of hind femur $643 \mu \mathrm{m}$; length of front tibia $325 \mu \mathrm{m}$, of middle tibia $428 \mu \mathrm{m}$, of hind tibia $528 \mu \mathrm{m}$; all tarsi lacking.

Hypopygium (figs. 47-50). Tergite IX with 14 setae. Anal point, $55 \mu \mathrm{m}$ long, $18 \mu \mathrm{m}$ wide at base, 7 $\mu \mathrm{m}$ wide at apex, spatulate, crest $V$-shaped and basally open. Laterosternite IX with 1 seta. Phallapodeme $67 \mu \mathrm{m}$ long, transverse sternapodeme $40 \mu \mathrm{m}$ long. Gonocoxite $78 \mu \mathrm{m}$ long, gonostylus $73 \mu \mathrm{m}$ long. Superior volsella (fig. 49) $27 \mu \mathrm{m}$ long, ovoid; inferior volsella $58 \mu \mathrm{m}$ long, median volsella (fig. 50) $51 \mu \mathrm{m}$ long, not markedly recurved, with several short ovoid distal plates with apical points. Inferior volsella with microtrichia, superior and median volsellae without microtrichia. HR 1.07; HV 2.79.

Remarks. $-R$. abonae sp. n. is very similar to the Palaearctic $R$. curtistylus Goetghebuer, but is distinguished by its pale coloration and low antennal ratio.

Distribution. - The species is known only from a small river in the West Usambara Mts in NE Tanzania. At the trapping site the river had moderate flow over mud, fine sand and larger stones.

\section{Rheotanytarsus fuscus (Freeman)}

(figs. 51-57)

Tanytarsus fuscus Freeman, 1954: 25.

Rheotanytarsus fuscus (Freeman), Freeman \& Cranston 1980: 200, pro parte.
Material examined. - SOUTH AFRICA: Cape province, Tulbagh Barrage, 1 đิ, 23 x 1953, K. M. F. Scott, (B. M. 1954 - 180) (BMNH); Natal province, Shooters Hill, 20,22 vii 1956, B. Stuckenberg (BMNH); Lesotho, mature ô pupa, 13 ii 1992, P. Scotney (PLH).

Diagnostic characters. - See keys

Male imago $(n=2-4)$

Total length 2.32-2.92, $2.59 \mathrm{~mm}$. Wing length 1.35-1.87 mm. Total length / wing length 1.56-1.72. Wing length / length of profemur 2.28-2.75. Thorax with dark brown vittae and postnotum, abdomen pale, legs pale with apical $1 / 4$ of femur darker.

Head. AR 0.36-0.52. Thirteenth flagellomere 196$225 \mu \mathrm{m}$ long. Temporal setae 9, including 3-4 inner verticals, 3 outer verticals and 2-3 postorbitals. Clypeus with 18-21 setae. Tentorium 89-111 $\mu \mathrm{m}$ long, 22-32 $\mu \mathrm{m}$ wide at sieve pore and 11-13 $\mu \mathrm{m}$ wide at posterior tentorial pit. Stipes 96-107 $\mu \mathrm{m}$ long, 15-24 $\mu \mathrm{m}$ wide. Palpomere lengths (in $\mu \mathrm{m}$ ): 2932, 32-33, 91-104, 82-111, 171-173. Fifth palpomere / third palpomere 1.62-1.88.

Thorax. Dorsocentrals 12-13, acrostichals 20 . Scutellum with 4-5 setae.

Wing. VR 1.56-1.57. R with 19-28 setae, R1 with 41-46, R4+5 with 64-70 setae, Sc bare, RM with 0-2, $\mathrm{M}$ with 0-1, M1+2 with 57-64, M3+4 with 37-39, $\mathrm{Cu}$ with 17-23, Cu1 with 19-21, PCu with 70-81 and An with 40-41 setae. Cells $m$ with 26-31 setae, $\mathrm{r} 4+5$ with about $400, \mathrm{~m} 1+2$ with about $350, \mathrm{~m} 3+4$ with about 200, cu with about 160 and an with about 100 setae.

Legs. Spur of front tibia 20-24 $\mu$ m long, spurs of middle tibia 9-11 and $11 \mu \mathrm{m}$ long; of hind tibia 1113 and 13-15 $\mu \mathrm{m}$ long, all excluding comb. Comb of middle tibia 13-15 $\mu \mathrm{m}$ long, of hind tibia 15-20 $\mu \mathrm{m}$ long. Width at apex of front tibia $40-42 \mu \mathrm{m}$, of middle tibia 33-42 $\mu \mathrm{m}$, of hind tibia $42-51 \mu \mathrm{m}$. Lengths and proportions of legs see table 7 .

Hypopygium (figs. 51-54). Tergite IX with 1014,12 setae. Anal point 60-70, $66 \mu \mathrm{m}$ long; 22-27, 25 $\mu \mathrm{m}$ wide at base; $7-13,9 \mu \mathrm{m}$ wide at apex; crest rounded and basally closed. Laterosternite IX with 2 
Table 8. Rheotanytarsus montanus, male. Lengths (in $\mu \mathrm{m}$ ) and proportions of legs.

\begin{tabular}{ccccccc} 
& $\mathrm{fe}$ & $\mathrm{ti}$ & $\mathrm{ta}_{1}$ & $\mathrm{ta}_{2}$ & $\mathrm{ta}_{3}$ & $\mathrm{ta}_{4}$ \\
\hline $\mathrm{p}_{1}$ & $453-480$ & $243-288$ & $589-628$ & $293-328$ & $218-228$ & 178 \\
$\mathrm{p}_{2}$ & $500-528$ & $357-386$ & $214-264$ & $100-128$ & $75-93$ & $57-64$ \\
$\mathrm{p}_{3}$ & $532-578$ & $418-482$ & $261-321$ & $178-182$ & $161-164$ & $103-107$ \\
\hline & $\mathrm{ta}_{5}$ & $\mathrm{LR}$ & $\mathrm{BV}$ & $\mathrm{SV}$ & $\mathrm{BR}$ & \\
\hline $\mathrm{p}_{1}$ & 93 & $2.36-2.59$ & $1.57-1.69$ & $1.11-1.21$ & $3.1(1)$ \\
$\mathrm{p}_{2}$ & $43-50$ & 0.60 & $3.50-3.90$ & $4.00-4.0$ & $4.6-5.7$ & \\
$\mathrm{p}_{3}$ & $57-64$ & $0.62-0.67$ & $2.41-2.69$ & $3.30-3.66$ & $4.7-7.1$ & \\
\hline
\end{tabular}

setae. Phallapodeme 73-86, $79 \mu \mathrm{m}$ long; transverse sternapodeme 52-71, $60 \mu \mathrm{m}$ long. Gonocoxite 107122, $113 \mu \mathrm{m}$ long; gonostylus 96-111, $104 \mu \mathrm{m}$ long. Superior volsella (fig. 53) 40-48, $44 \mu \mathrm{m}$ long, sickleshaped; inferior volsella 62-72, $68 \mu \mathrm{m}$ long; median volsella (fig. 54) 60-69, $63 \mu \mathrm{m}$ long, slightly Sshaped, with distal lamellae fused into single plate without terminal points. Inferior volsella with microtrichia, superior and median volsella without microtrichia. HR 1.06-1.12, 1.10; HV 2.32-2.68, 2.52.

\section{Pupa $(\mathrm{n}=1)$}

Total length $2.56 \mathrm{~mm}$. Exuviae pale with outer edges of cephalothorax dark.

Cephalothorax. Frontal apotome slightly granulose anteriorly. Thoracic horn missing. Frontal setae, median and lateral antepronotals and precorneals not observable. Anterior dorsocentrals also not observable. Nose of wing sheath $10 \mu \mathrm{m}$ long.

Abdomen (fig. 57). Tergite I bare; spine patches present on tergites II-V, rectangular on T II-III, circular on IV-V. Tergite II (fig. 55) with additional pair of posterior patches of very fine spinules. Median shagreen essentially absent, weak and sparse shagreen present caudolaterally on tergites IV and V. Number of spines on T II-V; 65, 60, 40, and 20. Caudal hooklets occupying approximately median $1 / 3$ of tergite II, about 60 hooklets. Caudal spur $14 \mu \mathrm{m}$ long. L-setae on segments II-V as 2, 2, 3, 3; all taeniate on segments V, 1 taeniate and two hairlike on IV and all hairlike on III and II. Anal lobe (fig. 56) without dorsal seta; 23 taeniae in fringe; longest taeniae $280 \mu \mathrm{m}$ long. Male genital sac overreaches anal lobe by 112 $\mu \mathrm{m}$.

Distribution. - The species is known only from streams in Cape and Natal provinces and Lesotho in South Africa.

\section{Rheotanytarsus montanus Lehmann (figs. 58-61)}

Rheotanytarsus montanus Lehmann 1979: 62.

Material examined. - D. R. CONGO: NE D. R. Congo, Kalengo, 1 ô, ultimo iv 1972, J. Lehmann (ZSM No. Ef / 1980); Irangi, Luoho, 1 đ, 3-7 iv 1984, light trap, E. G. Burmeister (ZSM). SOUTH AFRICA, Natal Province, Merrivale district, near Howick, 2931' E 30¹5'E1 ồ, 13-31 x 1990, at light, B. R. Stuckenberg, (ZMBN).

Diagnostic characters. - See keys.

Male imago ( $\mathrm{n}=1-3)$

Total length $2.16 \mathrm{~mm}$. Wing length 1.11-1.34 $\mathrm{mm}$. Total length / wing length 1.83. Wing length / length of profemur 2.44-2.79. Thorax with dark brown vittae and postnotum, abdomen dark, legs dark.

Head. AR 0.13-0.22. Thirteenth flagellomere 61$104 \mu \mathrm{m}$ long. Temporal setae 7-10, including 3-5 inner verticals, 2-3 outer verticals, and 1-3 postorbitals. Clypeus with 14-30 setae. Tentorium 100-104 $\mu \mathrm{m}$ long, 20-22 $\mu \mathrm{m}$ wide at sieve pore and 9-10 $\mu \mathrm{m}$ wide at posterior tentorial pit. Stipes $89-100 \mu \mathrm{m}$ long 20 $\mu \mathrm{m}$ wide. Palpomere lengths (in $\mu \mathrm{m}$ ): 26-27, 24-31, 74-80, 84-100, 144-158. Fifth palpomere / third palpomere 1.95-1.97.

Thorax. Dorsocentrals 10-12 in single row, acrostichals 20-22. Scutellum with 4-8 setae.

Wing. VR 1.41-1.45. R with 16-18 setae, R1 with 18-23, R4+5 with 38-47, Sc and M bare, RM with 12, M1+2 with 38-60, M3+4 with 25-27, Cu with 1620, Cu1 with $15-17, \mathrm{PCu}$ with $40-56$, and An with 23-29 setae. Cells m with $23-34$ setae, $r 4+5$ with about $300-350, \mathrm{~m} 1+2$ with about $300-350, \mathrm{~m} 3+4$ with 52-53, cu with 63-78 and an with 23-40 setae.

Legs. Spurs of front tibia 18-22 $\mu \mathrm{m}$ long; spurs of middle tibia 7-9 and 11-13 $\mu \mathrm{m}$ long, of hind tibia 11 and 13-15 $\mu \mathrm{m}$ long, all excluding comb. Combs 11$15 \mu \mathrm{m}$ long. Width at apex of front tibia $32-33 \mu \mathrm{m}$, of middle tibia 29-31 $\mu \mathrm{m}$, of hind tibia 30-35 $\mu \mathrm{m}$. Lengths and proportions of legs see table 8 . 
Hypopygium (figs. 58-61). Tergite IX with 17-20 setae. Anal point 49-58 $\mu \mathrm{m}$ long, $18-22 \mu \mathrm{m}$ wide at base; 6-7 $\mu \mathrm{m}$ wide at apex; crest $\mathrm{V}$-shaped and open. Laterosternite IX with 1 seta. Phallapodeme 64-82 $\mu \mathrm{m}$ long, transverse sternapodeme 38-48 $\mu \mathrm{m}$ long. Gonocoxite 89-108 $\mu \mathrm{m}$ long, gonostylus $80-88 \mu \mathrm{m}$ long. Superior volsella (fig. 60) 32-33 $\mu \mathrm{m}$ long, ovoid with posterior weak hook-like extension; inferior volsella 60-72 $\mu \mathrm{m}$ long, median volsella (fig. 61) 58$66 \mu \mathrm{m}$ long. Inferior volsella with microtrichia, superior and median volsellae without microtrichia. HR 1.11-1.23; HV 2.48.

Distribution. - The species is known from rivers in NE D. R. Congo, South Africa and Italy (Rossaro 1988).

\section{Rheotanytarsus transversus sp. $\mathrm{n}$.}

(figs. 62-71)

Type locality. - GHANA: Volta Region, Wli, Agumatsa Waterfalls.

Type material. - Holotype $q$ reared from pupa, GHANA: Volta Region, Wli, Agumatsa Waterfalls, 12 xi 1993, drift sample station 1, in between falls, NUFU project (ZMBN Type No. 318). Paratypes: 10 pupae as holotype (ZMBN, ZSM, RMB, BMNH).

Diagnostic characters. - See keys.

Etymology. - After the Latin transversus meaning horizontal, transverse referring to the transverse band of spines on tergites II and III of the abdomen of the pupa.

\section{Female $(\mathrm{n}=1)$}

Total length $1.84 \mathrm{~mm}$. Wing not measurable. Thorax with dark vittae, postnotum and pre-episternum. Legs and abdomen pale.

Head. AR not measurable. Lengths of flagellomeres 1-4 (in $\mu \mathrm{m}$ ): $55,27,29,33$. Terminal flagellomere lacking. Temporal setae 8 in single row, including 3 inner verticals, 3 outer verticals, and 2 postorbitals. Clypeus with 17 setae. Tentorium $45 \mu \mathrm{m}$ long, 12 $\mu \mathrm{m}$ wide at sieve pore and $6 \mu \mathrm{m}$ wide at posterior tentorial pit. Stipes $57 \mu \mathrm{m}$ long, $10 \mu \mathrm{m}$ wide. Lengths of palpomeres 1 and 2 (in $\mu \mathrm{m}$ ): 18; 18. Apical three segments broken off.

Thorax. Dorsocentrals 13, acrostichals 22. Scutellum with 5 setae.

Wing not measurable.

Legs. Spur of front tibia $14 \mu \mathrm{m}$ long, spurs of middle tibia 10 and $12 \mu \mathrm{m}$ long, of hind tibia 16 and 18 $\mu \mathrm{m}$ long, all excluding comb. Combs 10-14 $\mu \mathrm{m}$ long. Width at apex of front tibia and middle tibia each 29 $\mu \mathrm{m}$, of hind tibia $37 \mu \mathrm{m}$. Length of front femur 288 $\mu \mathrm{m}$, of middle femur $380 \mu \mathrm{m}$, of hind femur $548 \mu \mathrm{m}$; length of front tibia $172 \mu \mathrm{m}$, of middle tibia $320 \mu \mathrm{m}$, of hind tibia $440 \mu \mathrm{m}$; all tarsi lacking.

Abdomen. Number of setae on tergites I-VIII as: 69, 6-8, 7-9, 6-10, 6-10, 6-9, 6-9, 5-10. Number of setae on sternites I-VII as: 0, 2-3, 2-4, 2-6, 2-4, 3-4, 34. On sternite VIII 10-15 setae, 3-6 on each side of the genital fissure and 1-3 along lateral margin.

Genitalia (figs. 62-65). Gonocoxite with 1 setae. Tergite IX with 21 setae. Cercus $37 \mu \mathrm{m}$ long, $6 \mu \mathrm{m}$ wide at apex. Seminal capsule $37 \mu \mathrm{m}$ long including $10 \mu \mathrm{m}$ long neck, seminal capsule not sclerotized. Notum $51 \mu \mathrm{m}$ long.

Pupa ( $\mathrm{n}=10$ except when otherwise stated)

Total length 1.72-1.99, $1.82 \mathrm{~mm}$. Exuviae slightly dark.

Cephalothorax. Frontal apotome (fig. 66) smooth. Frontal setae 20-41, $23 \mu \mathrm{m}$ long. Thoracic horn (fig. 67) 224-264, $243 \mu \mathrm{m}$ long; 16-24, $19 \mu \mathrm{m}$ wide; with fine spinules in apical half. Median antepronotals 5588, $72 \mu \mathrm{m}$ long; lateral antepronotals $31-41,37 \mu \mathrm{m}$ long; both median and lateral antepronotals taeniate. Precorneals taeniate, close together; anterior precorneals 14-31, $22 \mu \mathrm{m}$ (5) long; median precorneals 31-51, $42 \mu \mathrm{m}$ long; posterior precorneals 66-98, 83 $\mu \mathrm{m}$ long. Anterior dorsocentrals Dc1 10-35, $17 \mu \mathrm{m}$ long; Dc2 33-47, $41 \mu \mathrm{m}$ long; Dc3 20-53, $39 \mu \mathrm{m}$ long; Dc4 10-20, $14 \mu \mathrm{m}$ long. Dc1 1-3, $2 \mu \mathrm{m}$ in front of Dc2; Dc2 45-61, $53 \mu \mathrm{m}$ in front of Dc3; and Dc3 $1-3,2 \mu \mathrm{m}$ in front of Dc4. Nose of wing sheath (fig. 68) $18-31,21 \mu \mathrm{m}$ long.

Abdomen (fig. 71). Tergite I bare; paired spines patches on tergites II-VI, patches on II (fig. 70) transverse, band-like, overlapping; transverse also on III, transverse oval to circular on IV-VI. Number of spines on T II-VI 130-160, 147; 80-115, 99; 65-85, 72 (8); 45-60, 52 (4);19-30, 25. Weak, not extensive, shagreen present posterior of patches on tergites IIIVI, most pronounced on tergite VI. Caudal hooklets occupying about median half of T II, about 50-70 hooklets. Caudal spur (fig. 69) 16-27, $18 \mu \mathrm{m}$ long. Number of lateral setae on segments II- VIII as 3, 3, 3, 3, 3, 4, 4; posterior $\mathrm{L}$ seta taeniate on $\mathrm{V}$, all taeniate on VI-VIII. Lengths (in $\mu \mathrm{m}$ ) of L3 and L4 on segment VIII 29-55, 38 (7); and 18-41, 31 (8). Anal lobe bare, with 6-9, 7 taeniae in fringe; longest taenia 80-120, $98 \mu \mathrm{m}$ long. Male genital sac overreaches anal lobe by $27-57,41 \mu \mathrm{m}$.

Remarks. $-R$. transversus sp. $\mathrm{n}$. is known only as female and pupa and can be easily separated from other pupae of the Afrotropical members of the guineensis group by the medially joined transverse bands on tergites II and III.

Distribution. - The species is known only from two small rivers in southern Ghana. 



78
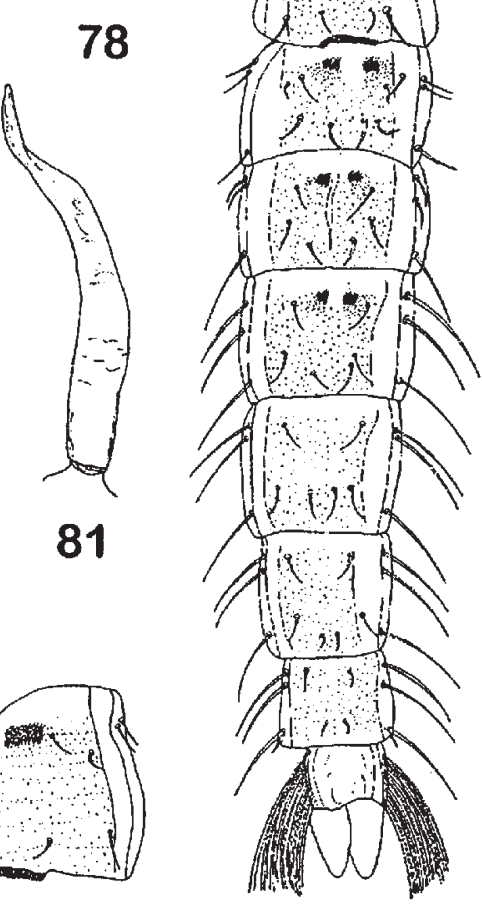

83

Figs. 72-83. Rheotanytarsus guineensis Kieffer, male and female imago, and pupa. - 72, 73; hypopygium, dorsal and ventral view; 74, superior volsella; 75, median volsella; 76, 77, female genitalia, ventral and dorsal view; 78, dorsomesal lobe; 79, ventrolateral lobe; 80 , apodeme lobe; 81 , thoracic horn; 82, tergite II of pupa; 83, tergites I-IX. 
Table 9. Rheotanytarsus guineensis, male. Lengths (in $\mu \mathrm{m}, \mathrm{n}=1-4$ on tarsomeres) and proportions of legs.

\begin{tabular}{|c|c|c|c|c|c|c|}
\hline & $\mathrm{fe}$ & $\mathrm{ti}$ & $\mathrm{ta}_{1}$ & $\mathrm{ta}_{2}$ & $\mathrm{ta}_{3}$ & \\
\hline $\begin{array}{l}\mathrm{p}_{1} \\
\mathrm{p}_{2} \\
\mathrm{p}_{3}\end{array}$ & $\begin{array}{l}460-928,846 \\
420-821,753 \\
504-893,830\end{array}$ & $\begin{array}{l}240-489,421 \\
400-643,602 \\
456-793,735\end{array}$ & $\begin{array}{c}528 \\
224-378,304 \\
536\end{array}$ & $\begin{array}{c}264 \\
108-178,140 \\
184-318\end{array}$ & $\begin{array}{c}184 \\
64-125,94 \\
136-261\end{array}$ & \\
\hline & $\mathrm{ta}_{4}$ & $\mathrm{ta}_{5}$ & LR & BV & SV & BR \\
\hline $\begin{array}{l}\mathrm{p}_{1} \\
\mathrm{p}_{2} \\
\mathrm{p}_{3}\end{array}$ & $\begin{array}{c}168 \\
68-79,77 \\
104-178\end{array}$ & $\begin{array}{c}88 \\
40-70,54 \\
72\end{array}$ & $\begin{array}{ll} & 2.20 \\
0 . & 60-0.61 \\
& 0.68\end{array}$ & $\begin{array}{c}- \\
3.37-3.96 \\
-\end{array}$ & $\begin{array}{c}- \\
3.42-3.76 \\
3.10\end{array}$ & $\begin{array}{c}- \\
5.0-5.1 \\
4.2\end{array}$ \\
\hline
\end{tabular}

\section{Rheotanytarsus guineensis Kieffer (figs. 72-83)}

\section{Rheotanytarsus guineensis Kieffer 1918: 73.}

Material examined. - D. R. CONGO: Elisabethville, 1 đे, 17 xii 1938, H. J. Brédo (R. Mus. Hist. Nat. Belg. I. G. 12.204) (BMNH). TANZANiA: Tanga Region, W. Usambara Mts, Mazumbai, Kaputu Stream, loc. 5, 1650 m a.s.l., $3 \hat{0}$ 2-6 xi 1990, Malaise trap, ZMBN Tanzania expedition; 40 , as above except loc. 10, $1420 \mathrm{~m}$ a.s.l., xi 1990 (ZMBN). KENYA: Meru National Park, 10, iii. 1983, E. J. Fittkau (ZSM). SOUTH AFRICA: Eastern Transvaal, Letaba River, 2 mature ô pupae, 21 xi 1990, (LET $30 \mathrm{E}-\mathrm{G}$ ) P. Scotney. 1 mature + pupa, except 22 v 1991 (LET 51 F-I). 28 51' S, 30 30' E, Mooi River at Keat's Drift, 1 mature $q$ pupa, 8 viii 1985 , B. K. Fowles (ZMBN No. 889).

Diagnostic characters. - See keys.

Male imago ( $n=8-11$ except when otherwise stated)

Total length 2.06-3.03, $2.72 \mathrm{~mm}$. Wing length 1.66-1.84, $1.74 \mathrm{~mm}$. Total length / wing length 1.59-1.76, 1.71 (7). Wing length / length of profemur 1.83-2.05, 1.95. Thorax dark brown, abdomen pale, legs dark apically.

Head. AR 0.57-1.03, 0.65. Thirteenth flagellomere 318-539, $364 \mu \mathrm{m}$ long. Temporal setae 6-8, 7 (7) in single row; including 3 (7) inner verticals; $1-3,2(7)$ outer verticals; and 2-3, 2 (7) postorbitals. Clypeus with 15-22, 18 setae. Tentorium 93-122, $103 \mu \mathrm{m}$ long; 22-33, $27 \mu \mathrm{m}$ wide at sieve pore and 10-18, 13 $\mu \mathrm{m}$ wide at posterior tentorial pit. Stipes 98-131, 113 $\mu \mathrm{m}$ long; $7-11,9 \mu \mathrm{m}$ wide. Palpomere lengths (in $\mu \mathrm{m}$ ): 22-39, 32; 24-39, 32; 88-131, 115 (4); 107-120 (3); 193 (1). Fifth palpomere / third palpomere 1.53 (1).

Thorax. Dorsocentrals 7-13, 11 in single row, acrostichals 18-26, 22. Scutellum with 4-8, 6 setae.

Wing $(n=6)$. VR 1.44-1.54, 1.50. R with 17-28, 22; R1 with 37-46, 42; R4+5 with 67-87, 77; Sc with 1821, 19; RM with 0-2, 1; M bare; M1+2 with 67-83, 73; M3+4 with 35-43, 39; Cu with 17-24, 21; Cu1 with 22-30, 24; PCu with 54-75, 66 and An with3241, 37 setae. Cells $m$ with 17-31, 27 setae; $r 4+5$ with about $400 ; \mathrm{m} 1+2$ with about $400 ; \mathrm{m} 3+4$ with about 200; cu with about 150 and an with 75-122, 104 se- tae. Squama bare.

Legs. Spurs of front tibia 14-33, 27 (7) $\mu \mathrm{m}$ long; spurs of middle tibia 8-13, 12 and 12-18, 14 (4) $\mu \mathrm{m}$ long, of hind tibia 12-22, 19 (7) and 14-24, 21 (6) $\mu \mathrm{m}$ long, all excluding comb. Comb of middle tibia 12$18,15 \mu \mathrm{m}$ long, of hind tibia 12-20, $18 \mu \mathrm{m}$ long. Width at apex of front tibia 32-51, $43 \mu \mathrm{m}$; of middle tibia 32-42, $39 \mu \mathrm{m}$; of hind tibia 36-51, $47 \mu \mathrm{m}$. Lengths and proportions of legs see table 9.

Hypopygium (figs. 72-75). Tergite IX with 9-14, 11 setae. Anal point 53-80, $63 \mu \mathrm{m}$ long, 20-31, 23 $\mu \mathrm{m}$ wide at base; $6-15,10 \mu \mathrm{m}$ wide at apex; crest rounded and basally closed. Laterosternite IX with 2 3, 2 setae. Phallapodeme 70-100, $85 \mu \mathrm{m}$ long; transverse sternapodeme 36-73, $48 \mu \mathrm{m}$ long. Gonocoxite 100-133, $111 \mu \mathrm{m}$ long; gonostylus 90-118, $103 \mu \mathrm{m}$ long. Gonostylus curved at apex. Superior volsella (fig. 74) 26-40, $32 \mu \mathrm{m}$ long, somewhat rectangular; inferior volsella 60-70, $65 \mu \mathrm{m}$ long; median volsella (fig. 75) 44-71, $57 \mu \mathrm{m}$ long, not markedly recurved, with several short ovoid distal plates without apical points. Inferior volsella with microtrichia, superior and median volsellae without microtrichia. HR 1.021.18, 1.09; HV 2.09-2.88, 2.61.

\section{Female $(\mathrm{n}=1-2)$}

Total length 2.39-2.92 mm. Wings not measurable. Thorax, abdomen and legs pale.

Head. AR 0.29-0.32. Lengths of flagellomeres (in $\mu \mathrm{m}):$ 72-90, 48-50, 56-58, 46-58, 72-76. Temporal setae 7 in single row, including 3 inner verticals, 2 outer verticals, and 2 postorbitals. Clypeus with 18 23 setae. Tentorium $92 \mu \mathrm{m}$ long, $28 \mu \mathrm{m}$ wide at sieve pore and $10 \mu \mathrm{m}$ wide at posterior tentorial pit. Palpomere lengths (in $\mu \mathrm{m}$ ): 28, 28, 80, 90, 146. Fifth palpomere / third palpomere 1.82 .

Thorax. Dorsocentrals 10-12, acrostichals 18-20. Scutellum with 3-5 setae.

Abdomen. Number of setae on tergites and sternites not countable.

Genitalia (fig. 76-80). Gonocoxite with no setae. Tergite IX with 35-40 setae. Cercus 52-56 $\mu \mathrm{m}$ long, 8-12 $\mu \mathrm{m}$ wide at apex. Seminal capsule, 68-78 $\mu \mathrm{m}$ 

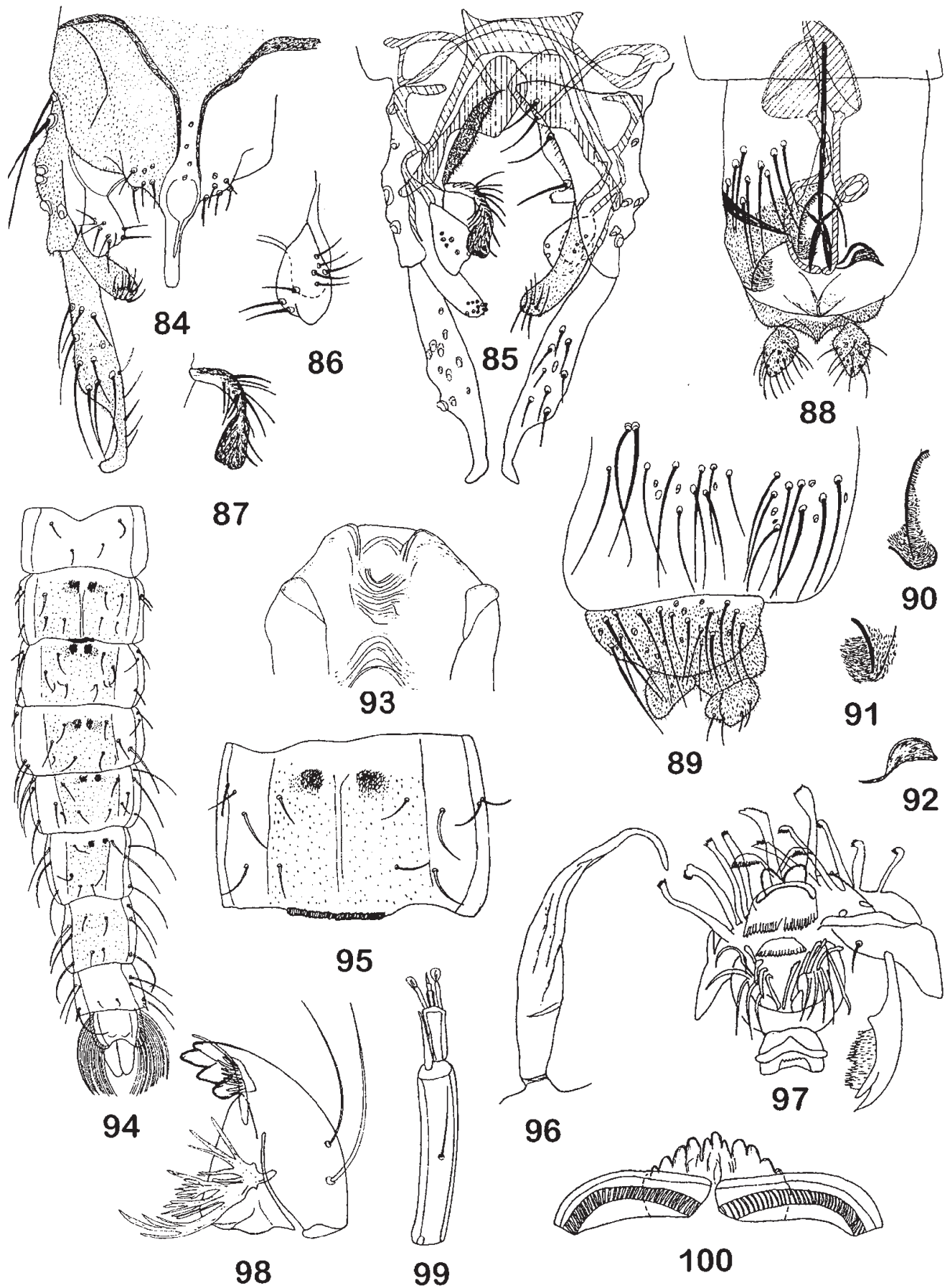

Figs. 84-100. Rheotanytarsus rioensis Langton et Armitage, male and female imagines, pupa and fourth instar larva. $-84,85$, hypopygium, dorsal and ventral view; 86 , superior volsella; 87 , median volsella; 88 , 89, female genitalia, ventral and dorsal view; 90, dorsomesal lobe; 91, ventrolateral lobe; 92, apodeme lobe; 93, frontal apotome of pupa; 94, tergites I-IX; 95, tergite II; 96, thoracic horn; 97, pecten epipharyngis of larva; 98, mandible; 99, larval antenna; 100, mentum. 
Table 10. Rheotanytarsus rioensis, male. Lengths (in $\mu \mathrm{m}$ ) and proportions of legs.

\begin{tabular}{|c|c|c|c|c|c|c|c|c|c|c|}
\hline & $\mathrm{fe}$ & $\mathrm{ti}$ & $\mathrm{ta}_{1}$ & $\mathrm{ta}_{2}$ & $\mathrm{ta}_{3}$ & $\mathrm{ta}_{4}$ & $\mathrm{ta}_{5}$ & LR & BV & SV \\
\hline $\mathrm{p}_{1}$ & - & 288 & 604 & 340 & 260 & - & - & 2.10 & - & - \\
\hline $\mathrm{p}_{2}$ & 480 & 440 & 272 & 128 & 88 & 60 & 56 & 0.62 & 3.59 & 3.38 \\
\hline $\mathrm{p}_{3}$ & 600 & 560 & 332 & 220 & 180 & 128 & 72 & 0.59 & 2.49 & 3.38 \\
\hline
\end{tabular}

long including $8 \mu \mathrm{m}$ long neck with sclerotization. Notum 146-160 $\mu \mathrm{m}$ long.

Pupa ( $\mathrm{n}=3-4$ except when otherwise stated) Total length 2.32-3.38, $2.69 \mathrm{~mm}$. Exuviae slightly dark.

Cephalothorax. Frontal apotome smooth. Frontal setae not measurable. Thoracic horn (fig. 81) 130-156 $\mu \mathrm{m}$ long; 20-24 $\mu \mathrm{m}$ wide; and completely bare throughout entire length. Median and lateral antepronotals not measurable. Precorneals close together; anterior precorneals 60 (1) $\mu \mathrm{m}$ long and taeniate; median precorneals 28 (1) $\mu \mathrm{m}$ long; posterior precorneals 160 (1) $\mu \mathrm{m}$ long, both taeniate. Anterior dorsocentrals not measurable. Nose of wing sheath 10-12 $\mu \mathrm{m}$ long.

Abdomen (fig. 83). Tergite I bare, paired spines patches on tergites II-V, rectangular on II- IV, circular on V. Tergite II (fig. 82) bare posteriorly. Number of spines on T II-V 35-85, 60; 25-80, 55; 30-65, 46; 20-40, 31. Caudal hooklets occupying about median $1 / 2-1 / 3$ of T II, about $60-80,69$ hooklets. Caudal spur $10-14,12 \mu \mathrm{m}$ long. Number of lateral setae on segments II-VIII not countable due to folding of segments. Anal lobe bare, with 22-27, 24 taeniae in fringe; longest taenia $240-460 \mu \mathrm{m}$ long. Male genital sac overreaches anal lobe by $96-110(2) \mu \mathrm{m}$.

Remarks. - There is a very large variation in size and antennal ratio which is not evident in all measurements since several of the smaller specimens not were measurable in all details. The wing length, for instance, of one specimen appeared to be only about $0.95 \mathrm{~mm}$. However, $R$. guineensis Kieffer can easily be separated from other Afrotropical species on the shape of the gonostylus which is abruptly tapered in apical half and curved at apex as well as having setae on subcosta.

Distribution. - The species is known from D. R. Congo, a small stream in the West Usumbara Mts. in NE Tanzania, Meru National Park in Kenya, from Eastern Transvaal in South Africa, Guinea and Senegal.

\section{Rheotanytarsus rioensis Langton et Armitage (figs. 84-100) \\ Rheotanytarsus rioensis Langton \& Armitage, 1995:11; Lang- ton 1998: 16. \\ Rheotanytarsus Pe 2, Langton 1991: 330.}

Material examined. - SOUTH AFRICA: Kruger National Park, 1 mature ô pupa, 1 mature ô pupa 12 iv 1985,21 x 1986, P. Scotney (KNP 344); Olifants River, 1 mature $q$ pupa, 28 vii 1993, P. Scotney (CH1). 2 mature ô pupa, 4 mature + pupa.; 28 51' S, 30 30' E, Mooi River at Keat's Drift, 2 mature $\delta$ pupa, 3 mature $q$ pupae, 1 pupa, 3 larvae, 8 viii 1985, B. K. Fowles (PLH).

Diagnostic characters. - See keys.

Although the species is well described by Langton \& Armitage (1995) the South African population is described here as some minor differences may indicate that the population may not be conspecific.

Male imago ( $n=3-4$ except when otherwise stated)

Total length 2.76-3.08, $2.91 \mathrm{~mm}$. Thorax, abdomen and legs pale brown.

Head. Antenna lost. Temporal setae 8-9; including 3-4, 3 inner verticals; 3 outer verticals; and 2-3, 3 postorbitals. Tentorium 94-110, $103 \mu \mathrm{m}$ long, 40$46,43 \mu \mathrm{m}$ wide at sieve pore and 10-14, $12 \mu \mathrm{m}$ wide at posterior tentorial pit. Lengths of palpomeres (in $\mu \mathrm{m}, \mathrm{n}=1-2): 30-32,26-28,70-80,80-86,152$. Fifth palpomere / third palpomere 1.90 (1).

Thorax. Dorsocentrals 8-10, 9; acrostichals 20-22. Scutellum with 4 setae.

Wing not measurable.

Legs $(n=1)$. Spurs of front tibia $18 \mu \mathrm{m}$ long; spurs of middle tibia 12 and $14 \mu \mathrm{m}$ long, of hind tibia 14 and $18 \mu \mathrm{m}$ long, all excluding comb. Combs 12-14 $\mu \mathrm{m}$ long. Width at apex of front tibia $46 \mu \mathrm{m}$, of middle tibia $38 \mu \mathrm{m}$, of hind tibia $44 \mu \mathrm{m}$. Lengths and proportions of legs see table 10 .

Hypopygium (figs. 84-87). Tergite IX with 11- 17 setae. Anal point 62-70, $65 \mu \mathrm{m}$ long; 20-22, $21 \mu \mathrm{m}$ wide at base; 6-8, $7 \mu \mathrm{m}$ wide at apex. Crest well developed and closed with 4-5, 4 setae between anal tergite bands that are separated. Laterosternite IX with 1 seta. Phallapodeme 82-100, $88 \mu \mathrm{m}$ long; transverse sternapodeme 50-60, $53 \mu \mathrm{m}$ long. Gonocoxite 102112, $107 \mu \mathrm{m}$ long; gonostylus 112-118, $114 \mu \mathrm{m}$ long. Superior volsella (fig. 86) 32-36, $34 \mu \mathrm{m}$ long, oblong with slightly pointed apex; inferior volsella 66-70, $67 \mu \mathrm{m}$ long; median volsella (fig. 87) 40-52, $45 \mu \mathrm{m}$ long, not markedly recurved, with distal lamelliform setae fused into single narrow plate without apical points. Inferior volsella with microtrichia, superior and median volsellae without microtrichia. HR 0.90-0.98, 0.94; HV 2.44-2.75, 2.54. 
Female $(\mathrm{n}=3-4)$

Total length $2.30-2.78 \mathrm{~mm}$. Wing not measurable. Thorax with slightly dark vittae, postnotum and pre-episternum. Legs and abdomen pale.

Head. AR 0.28-0.34, 0.31. Lengths of flagellomeres (in $\mu \mathrm{m}$ ): 64-74, 68; 46-54, 49; 50-60, 54; 50-60, 54; 64-76, 70. Temporal setae 9-10, 9 in single row, including 3-4, 3 inner verticals; 3 outer verticals, and 3 postorbitals.

Thorax. Dorsocentrals 8-13,11; acrostichals 18-22, 20. Scutellum with 4-5, 4 setae. Genitalia (fig. 88-92). Gonocoxite with 1 setae. Tergite IX with 33-50, 41 setae. Cercus 44-52, $48 \mu \mathrm{m}$ long; 6-10, $9 \mu \mathrm{m}$ wide at apex. Seminal capsule $72-80,75 \mu \mathrm{m}$ long; including 16-22, $19 \mu \mathrm{m}$ long neck. Notum 136-160, $149 \mu \mathrm{m}$ long.

Pupa ( $\mathrm{n}=9$ except when otherwise stated)

Total length 2.76-3.28, $2.95 \mathrm{~mm}$. Exuviae slightly dark.

Cephalothorax. Frontal apotome (fig. 93) smooth. Frontal setae, median antepronotals and lateral not observable. Thoracic horn (fig. 96) 120-208, 163 (7) $\mu \mathrm{m}$ long; 24-28, 26 (7) $\mu \mathrm{m}$ wide and completely bare. Anterior precorneals 70 (1) $\mu \mathrm{m}$ long, posterior precorneals 100-150 (2) $\mu \mathrm{m}$ long and taeniate. Anterior dorsocentrals Dc1 20-24, 21 (5) $\mu \mathrm{m}$ long; Dc2 1432, 25 (5) $\mu \mathrm{m}$ long; Dc3 18-32, 26 (6) $\mu \mathrm{m}$ long; Dc4 12-22, 18 (6) $\mu \mathrm{m}$ long. Dc1 2-4, 4 (6) $\mu \mathrm{m}$ in front of Dc2; Dc2 110-154, 134 (6) $\mu \mathrm{m}$ in front of Dc3; and Dc3 2-4, $3 \mu \mathrm{m}$ in front of Dc4. Nose of wing sheath 10-16, 11 (6) $\mu \mathrm{m}$ long.

Abdomen (fig. 94). Tergite I bare; paired spines patches on tergites II-VI, rectangular on II-III, circular on IV-VI. Number of spines on T II-VI; 50-60, 55; 45-60, 54; 30-55, 48; 30-50, 39; 20-30, 25. Extensive shagreen present posterior of patches on tergites III-VI, most pronounced on tergite VI. Caudal hooklets occupying about median half of T II (fig. 95), about 60-90, 70 (7) hooklets. Caudal spur 16-24, $19 \mu \mathrm{m}$ long. L-setae on segments II-VIII as 2, 2, 3, 3, 3, 3, 3; all taeniate on segments V-VIII, 1 taeniate and two hairlike on IV and all hairlike on III and II. Lengths (in $\mu \mathrm{m}$ ) of L3 and L4 on segment VIII 180 (1) and 220 (1). Anal lobe bare, with 25-34, 29 (8) taeniae in fringe; longest taenia 200-360, 268 (5) $\mu \mathrm{m}$ long. Male genital sac overreaches anal lobe by $110-$ $128,118(4) \mu \mathrm{m}$.

\section{Fourth instar larva $(\mathrm{n}=1)$}

Total length $2.98 \mathrm{~mm}$. Head capsule length 0.18 $\mathrm{mm}$.

Head. Antenna as in Fig. 99. Length of antennal segments (in $\mu \mathrm{m}$ ): 102, 22, 6, 4, 4. AR 2.83. Basal antennal segment $16 \mu \mathrm{m}$ wide, distance from base to ring organ $4 \mu \mathrm{m}$, to basal mark of seta $60 \mu \mathrm{m}$. Blade
$22 \mu \mathrm{m}$ long, accessory blade $10 \mu \mathrm{m}$ long. Apical style of second segment $8 \mu \mathrm{m}$ long; Lauterborn organ 6 $\mu \mathrm{m}$ long, pedicel $7 \mu \mathrm{m}$ long. Pecten epipharyngis (fig. 97) a simple broad comb without indication of division into parts. Posterior chaetulae laterales with conspicuously long branches. Premandible $50 \mu \mathrm{m}$ long. Mandible (fig. 98) $92 \mu \mathrm{m}$ long. Mentum (fig. 100) $64 \mu \mathrm{m}$ wide; with median tooth $12 \mu \mathrm{m}$ wide, with lateral notches which may be more or less worn down; ventromental plate width / length 3.89, number of ventromental plate striations about 40 . Postmentum $100 \mu \mathrm{m}$ long.

Abdomen. Procercus $28 \mu \mathrm{m}$ long; $20 \mu \mathrm{m}$ wide; anal setae $380 \mu \mathrm{m}$ long. Supra-anal seta $80 \mu \mathrm{m}$ long; length of supra-anal setae / length of anal setae 0.21. Posterior parapods $120 \mu \mathrm{m}$ long. Anal tubuli not observable.

\section{Third instar larvae $(\mathrm{n}=2)$}

Total length 2.12-2.16 mm. Head capsule length $0.15-0.16 \mathrm{~mm}$.

Head. Length of antennal segments (in $\mu \mathrm{m}$ ): 80-90, 24-26, 8, 4-6, 4. AR 1.90-2.14. Basal antennal segment $14 \mu \mathrm{m}$ wide, distance from base to ring organ $2 \mu \mathrm{m}$; to basal mark of seta $42-46 \mu \mathrm{m}$. Blade 22-26 $\mu \mathrm{m}$ long, accessory blade 10-14 $\mu \mathrm{m}$ long. Apical style of second segment $12 \mu \mathrm{m}$ long, Lauterborn organ 4-6 $\mu \mathrm{m}$ long, pedicel $6 \mu \mathrm{m}$ long. Premandible 48-50 $\mu \mathrm{m}$ long. Mandible 74-76 $\mu \mathrm{m}$ long. Mentum $62 \mu \mathrm{m}$ wide, with median teeth $10 \mu \mathrm{m}$ wide, ventromental plate width / length 3.30-3.50, number of ventromental plate striations about 40, postmentum 100-106 $\mu \mathrm{m}$ long.

Abdomen. Procercus 20-24 $\mu \mathrm{m}$ long, 16-18 $\mu \mathrm{m}$ wide; anal setae 250-300 $\mu \mathrm{m}$ long. Supra-anal seta 60-70 $\mu \mathrm{m}$ long; length of supra-anal setae / length of anal setae $0.20-0.28$. Posterior parapods $120-130 \mu \mathrm{m}$ long. Anal tubuli not observable.

Remarks. - Most of the differences between the South African population and the one described from the Canary Islands may be explained as a result of the specimens described here being from mature pupae. The leg ratios of the middle and hind legs in Langton \& Armitage (1995) are inverted. R. rioensis Langton \& Armitage is similar to $R$. guineensis Kieffer but can be easily separated by the number of spine patches on the tergites of the pupa; II-VI in $R$. rioensis and II-V in $R$. guineensis. The anal point of the male is narrower, and its median volsella shorter and with a wider plate than that of $R$. guineensis. $R$. pela (Roback) from Peru (Kyerematen \& Andersen 2000) is surprisingly similar and must belong in the same group. However, $R$. pela does not fall in the guineensis group without making this a part of a constraint (Kyerematen \& Sæther 2000).

Distribution. - The species is known from the Canary Islands and South Africa. 
Table 11. Rheotanytarsus aquilus, male. Lengths (in $\mu \mathrm{m}$ ) and proportions of legs.

\begin{tabular}{ccccccc} 
& $\mathrm{fe}$ & $\mathrm{ti}$ & $\mathrm{ta}_{1}$ & $\mathrm{ta}_{2}$ & $\mathrm{ta}_{3}$ & $\mathrm{ta}_{4}$ \\
\hline $\mathrm{p}_{1}$ & $293-303$ & $164-168$ & 382 & 178 & 136 & 100 \\
$\mathrm{p}_{2}$ & 357 & $239-250$ & $129-139$ & 54 & $43-46$ & 32 \\
$\mathrm{p}_{3}$ & $368-378$ & $278-303$ & $164-178$ & $104-107$ & $100-111$ & $57-64$ \\
\hline & $\mathrm{ta}_{5}$ & $\mathrm{LR}$ & $\mathrm{BV}$ & $\mathrm{SV}$ & $\mathrm{BR}$ \\
\hline $\mathrm{p}_{1}$ & 57 & 2.28 & 1.81 & 1.23 & 3.2 \\
$\mathrm{p}_{2}$ & 29 & $0.54-0.56$ & $4.61-4.64$ & $4.36-4.64$ & $2.9-3.8$ \\
$\mathrm{p}_{3}$ & $36-43$ & 0.59 & $2.65-2.73$ & $3.82-4.04$ & $3.7-4.4$ \\
\hline
\end{tabular}

\section{The ceratophylli group}

The pupae have thoracic horn without median bend, tergites II-V or II-VI with paired anterior circular patches of spines and sometimes with interspecific variation; tergite II with posterior shagreen arranged into two groups; segment VIII with caudolateral comb of 3-6 curved, thorn-like spurs except in R. barrengaryensis with single spur, and anal lobe with taeniate or hair-like dorsal seta.

The male imagines of the group have posterior margin of tergite IX straight or, in the group in its strictest sense, with shoulders or projections to each side of the anal point; median volsella reaching apex of inferior volsella, with setae fused into apical plate(s), usually with points; superior volsella rounded or with knob-like posterior projection, digitus mostly reduced, median volsella not reaching beyond apex of superior volsella in the strict group, extending beyond superior volsella, but not reaching apex of inferior volsella in the group in its wider sense; gonostylus not abruptly tapered, or occasionally with parallelsided apical portion.

\section{Rheotanytarsus aquilus sp. n. (figs. 101-107).}

Type locality. - GHANA: Brong - Ahafo Region, Kintampo falls.

Type material. - Holotype $\delta$, GHANA: Brong Ahafo Region, Kintampo Falls, 13 ii 1993, sweep net, NUFU project (ZMBN Type No. 319). Paratype: đิ, Ghana: Eastern Region, Kibi, Subri River, 4 ii 1993, light trap, NUFU project (ZMBN).

\section{Diagnostic characters. - See key}

Etymology. - From Latin aquilus, dark - coloured, referring to the very dark colour of the thorax of the species.

\section{Male imago $(\mathrm{n}=1-2)$}

Total length 1.14-1.32 mm. Wing length 0.70$0.74 \mathrm{~mm}$. Total length / wing length 1.62-
1.79. Wing length / length of profemur 2.40-2.43. Thorax including postnotum dark brown, abdomen pale, legs pale brown with apical $1 / 3$ of femur darker.

Head. Antennae with 12 flagellomeres. AR 0.14. Twelfth flagellomere $64 \mathrm{~mm}$ long. Temporal setae 810 , including 4 inner verticals, $2-3$ outer verticals, and 2-3 postorbitals. Clypeus with 11-17 setae. Tentorium (fig. 101) 44-62 $\mu \mathrm{m}$ long, 11-22 $\mu \mathrm{m}$ wide at sieve pore, 7-9 $\mu \mathrm{m}$ wide at posterior tentorial pit. Stipes 55-67 $\mu \mathrm{m}$ long, 4-7 $\mu \mathrm{m}$ wide. Palpomere lengths (in $\mu \mathrm{m}$ ): 15-18, 18, 42, 60, 107-111. Fifth palpomere / third palpomere 2.50-2.53.

Thorax (fig. 102). Dorsocentrals 12-13 in single row, acrostichals 14 . Scutellum with 4 setae.

Wing (fig. 103). VR 1.54-1.56. R with 11-13 setae, R1 with 9-11, R4+5 with 29-30 setae, Sc and M bare, RM with $1, \mathrm{M} 1+2$ with $27-29, \mathrm{M} 3+4$ with $16, \mathrm{Cu}$ with 9-12, Cu1 with 9-10, $\mathrm{PCu}$ with 27-28, and An with 17-20 setae. Cells $m$ with $21-22$ setae, $r 4+5$ with $107-127, \mathrm{~m} 1+2$ with $130-150, \mathrm{~m} 3+4$ with $21-22$, cu with 37-38, and an with 6-15 setae.

Legs. Spur of front tibia $13 \mu \mathrm{m}$ long, spurs of middle tibia 7-9 and $11 \mu \mathrm{m}$ long, of hind tibia 7-9 and 7$13 \mu \mathrm{m}$ long, all excluding comb. Combs 9-15 $\mu \mathrm{m}$ long. Width at apex of front tibia $24-33 \mu \mathrm{m}$, of middle tibia 22-31 $\mu \mathrm{m}$, of hind tibia 27-31 $\mu \mathrm{m}$. Lengths and proportions of legs see table 11.

Hypopygium (figs. 104-107). Tergite IX with 1522 setae. Anal point 40-44 $\mu \mathrm{m}$ long, $18 \mu \mathrm{m}$ wide at base; crest V-shaped and open. Laterosternite IX with 5-6 setae. Phallapodeme 42-47 $\mu \mathrm{m}$ long, transverse sternapodeme 29-33 $\mu \mathrm{m}$ long. Gonocoxite 67-71 $\mu \mathrm{m}$ long, gonostylus 53-60 $\mu \mathrm{m}$ long. Superior volsella (fig. 106) $24 \mu \mathrm{m}$ long, oval; inferior volsella 44-47 $\mu \mathrm{m}$ long; median volsella (fig. 107) 33-38 $\mu \mathrm{m}$ long, slightly S-shaped, with distal lamellae fused into single plate with terminal points. Inferior volsella with microtrichia, superior and median volsellae without microtrichia. HR 1.18-1.25; HV 2.21-2.23. 

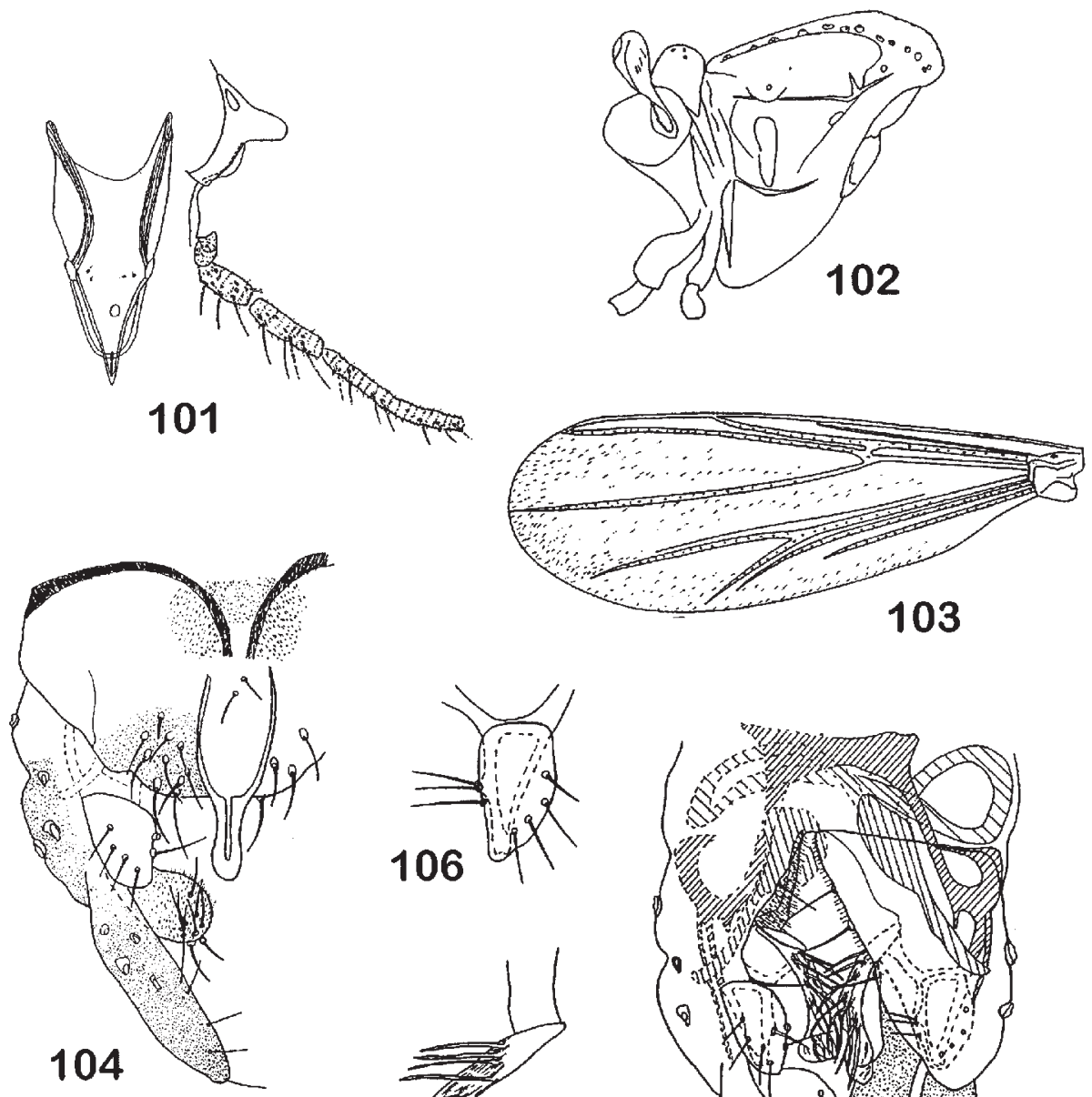

103
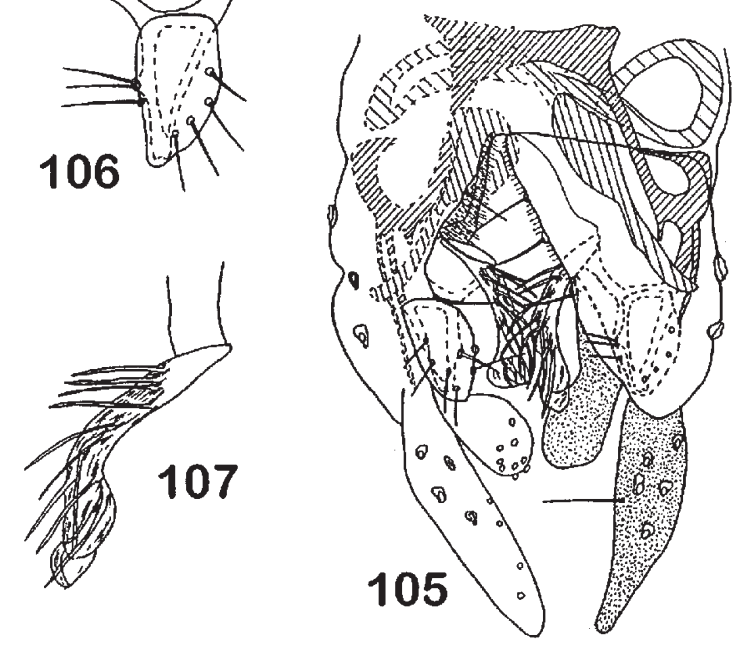

Figs. 101-107. Rheotanytarsus aquilus sp. n., male imago. - 101, cibarial pump, tentorium, stipes and palp; 102, thorax; 103, wing; 104, 105, hypopygium, dorsal and ventral view; 106, superior volsella; 107 , median volsella. 
Table 12. Rheotanytarsus ceratophylli, male. Lengths (in $\mu \mathrm{m}$ ) and proportions of legs.

\begin{tabular}{lcccccc} 
& $\mathrm{fe}$ & $\mathrm{ti}$ & $\mathrm{ta}$ & $\mathrm{ta}_{2}$ & $\mathrm{ta}_{3}$ & $\mathrm{ta}_{4}$ \\
\hline $\mathrm{p}_{1}$ & $438-580,492$ & $230-300,256$ & $593-600(2)$ & $289-303(2)$ & $218(2)$ & $153(2)$ \\
$\mathrm{p}_{2}$ & $392-560,481$ & $335-480,393$ & $200-252,228$ & $108-148,126(5)$ & $81-100,89(5)$ & $54-80,64(5)$ \\
$\mathrm{p}_{3}$ & $477-624,544$ & $311-576,480$ & $336-380(3)$ & $189-216(3)$ & $157-188(3)$ & $82-120(3)$ \\
\hline & $\mathrm{ta}_{5}$ & $\mathrm{LR}$ & $\mathrm{SV}$ & $\mathrm{BV}$ & $\mathrm{BR}$ & \\
\hline $\mathrm{p}_{1}$ & $82(2)$ & $2.00-2.02(2)$ & $1.91-1.92(2)$ & $1.41-1.42(2)$ & $3.4-3.6(2)$ & \\
$\mathrm{p}_{2}$ & $42-56,48(5)$ & $0.52-0.63,0.57$ & $3.36-3.89,3.62(5)$ & $3.74-4.13,3.94$ & $5.1-6.0(3)$ & \\
$\mathrm{p}_{3}$ & $61-68(3)$ & $0.61-0.65,0.63(4)$ & $2.67-2.85(3)$ & $3.16-3.31,3.23(4)$ & $6.3-5.3(3)$ & \\
\hline
\end{tabular}

\section{Rheotanytarsus ceratophylli (Dejoux)}

(figs. 108-119)

Tanytarsus (Rheotanytarsus) ceratophylli Dejoux, 1973: 65.

Material examined. - SENEGAL: Kedougou, Etiess, $10 \hat{\jmath}$ and 10 , 15 x 1972, C. Dejoux. GHANA: Greater Accra Region, Weija, 29 i 1932, 2 , light trap, NUFU project (ZMBN). NIGERIA: Kankiya, xii 56 - i 57, 20 , as Tanytarsus angustus Freeman B. McMillan. B.M. 1957-97; Zaria, 11 xi 1956, 10 , as Tanytarsus angustus Freeman, B. McMillan, B. M. 1956-723 (BMNH).

Diagnostic characters. - See keys.

Male imago ( $\mathrm{n}=8-10$ except when otherwise stated)

Total length 1.73-1.94, $1.84 \mathrm{~mm}$. Wing length 1.02-1.28, $1.09 \mathrm{~mm}$. Total length / wing length 1.60-1.93, 1.77. Wing length / length of profemur 2.16-2.34, 2.19. Thorax, and legs dark brown, abdomen conspicuously banded.

Head. AR 0.57-0.68, 0.62. Thirteenth flagellomere 242-316, $272 \mu \mathrm{m}$ long. Temporal setae 7-10, 8; including 3-4, 3 inner verticals; 2-4, 3 outer verticals; and 2-3, 2 postorbitals. Clypeus with 15-20, 17 setae. Tentorium (fig. 108) 72-80, $75 \mu \mathrm{m}$ long; 16-26, 21 $\mu \mathrm{m}$ wide at sieve pore; $8-12,10 \mu \mathrm{m}$ wide at posterior tentorial pit. Stipes 84-124, $99 \mu \mathrm{m}$ long; 20-34, 24 $\mu \mathrm{m}$ wide. Length of palpomeres (in $\mu \mathrm{m}): 22-30,25$; 22-32, 28; 60-82, 71; 67-100, 85; 130-152, 139 (5); third palpomere / fifth palpomere 1.66-1.94, 1.81 (5).

Thorax (fig. 110). Dorsocentrals 5-8, 7; acrostichals 18-22, 20. Scutellum with 2-5, 3 setae.

Wing (fig. 109). VR 1.44-1.53, 1.48. R with 13-19, 16 setae; R1 with $18-23,20$; R4+5 with 34-47, 41; Sc bare. $M$ with $0-2,0$; $R M$ with $0-2,1$; M1+2 with 3855, 46; M3+4 with 20-31, 25; Cu with 13-19, 16; Cu1 with 13-19, 15; PCu with 34-48, 39; and An with 23-29, 26 setae. Cells $m$ with 2 setae, $r 4+5$ with about $120, \mathrm{~m} 1+2$ with about $100, \mathrm{~m} 3+4$ with 30 , cu with 10 , and an with 10 setae.

Legs. Spur of front tibia 12-16, $13 \mu \mathrm{m}$ long; spurs of middle tibia 10-13, 10 and 12-15, $13 \mu \mathrm{m}$ long; of hind tibia 11-12, 12 (7) and 14-15, 14 (7) $\mu \mathrm{m}$ long, all excluding comb. Combs 10-16, $13 \mu \mathrm{m}$ long. Width at apex of front tibia 30-36, $33 \mu \mathrm{m}$; of middle tibia 2832, $30 \mu \mathrm{m}$; of hind tibia 30-38, $35 \mu \mathrm{m}$. Lengths and proportions of legs see table 12 .

Hypopygium (figs. 111-114). Tergite IX with 810, 9 setae. Tergite IX with shoulders to each side. Anal point 52-68, $61 \mu \mathrm{m}$ long; 20-26, $22 \mu \mathrm{m}$ wide at base; 6-10, $8 \mu \mathrm{m}$ wide at apex. Crest well developed and basally rounded with 4-6, 5 setae between anal tergite bands. Laterosternite IX with 1-2, 1 setae. Phallapodeme 60-74, $66 \mu \mathrm{m}$ long; transverse sternapodeme 40-50, $47 \mu \mathrm{m}$ long. Gonocoxite 80-88, 85 $\mu \mathrm{m}$ long; gonostylus 72-84, $78 \mu \mathrm{m}$ long. Superior volsella (fig. 113) 28-38, $33 \mu \mathrm{m}$ long, oblong; inferior volsella $62-72,67 \mu \mathrm{m}$ long; median volsella (fig. 114) 40-50, $46 \mu \mathrm{m}$ long, relatively short, with apical lamelliform setae not fused into plate with apical points. Inferior volsella with microtrichia, superior and median volsellae without microtrichia. HR 1.021.17, 1.09; HV 2.11-2.67, 2.38.

Female ( $n=8-10$ except when otherwise stated)

Total length $1.12-1.64,1.29 \mathrm{~mm}$. Wing length 0.86-1.08, $0.95 \mathrm{~mm}$. Total length / wing length 1.26-1.80, 1.38. Wing length / length of profemur 2.08-2.67, 2.49. Thorax, abdomen and legs pale.

Head. Lengths of flagellomeres (in $\mu \mathrm{m})$ : 42-66, 56 (5); 36-66 (3); 34-48 (2); 30 (1); 58 (1). Temporal setae $6-8,7$ (7) in single row; including $3(7)$ inner verticals, 2-3, 3 (7) outer verticals; and 1-2, 2 (7) postorbitals. Clypeus with 11-19, 15 setae. Tentorium 40-76, $63 \mu \mathrm{m}$ long; 8-12, $10 \mu \mathrm{m}$ wide at sieve pore; 4$6,5 \mu \mathrm{m}$ wide at posterior tentorial pit. Stipes 60-104, $85 \mu \mathrm{m}$ long; 12-28, 20 (7) $\mu \mathrm{m}$ wide. Palpomere 1-4, lengths (in $\mu \mathrm{m}$ ): 18-30, 21; 18-34, 23; 50-62, 58; 6470 (2).

Thorax. Dorsocentrals 8-14, 9; acrostichals 16-22, 18. Scutellum with 2-4, 3 setae.

Wing. VR 1.32-1.63, 1.47. R with 10-18, 13; R1 with 12-30, 18; R4+5 with 24-47, 38; Sc and M bare. RM with 0-2, 1 setae. M1+2 with 25-56, 39; M3+4 with 14-28, 21; Cu with 9-16, 13; Cu1 with 9-17, 12; PCu with 26-38, 30; and An with 15-26, 19 se- 


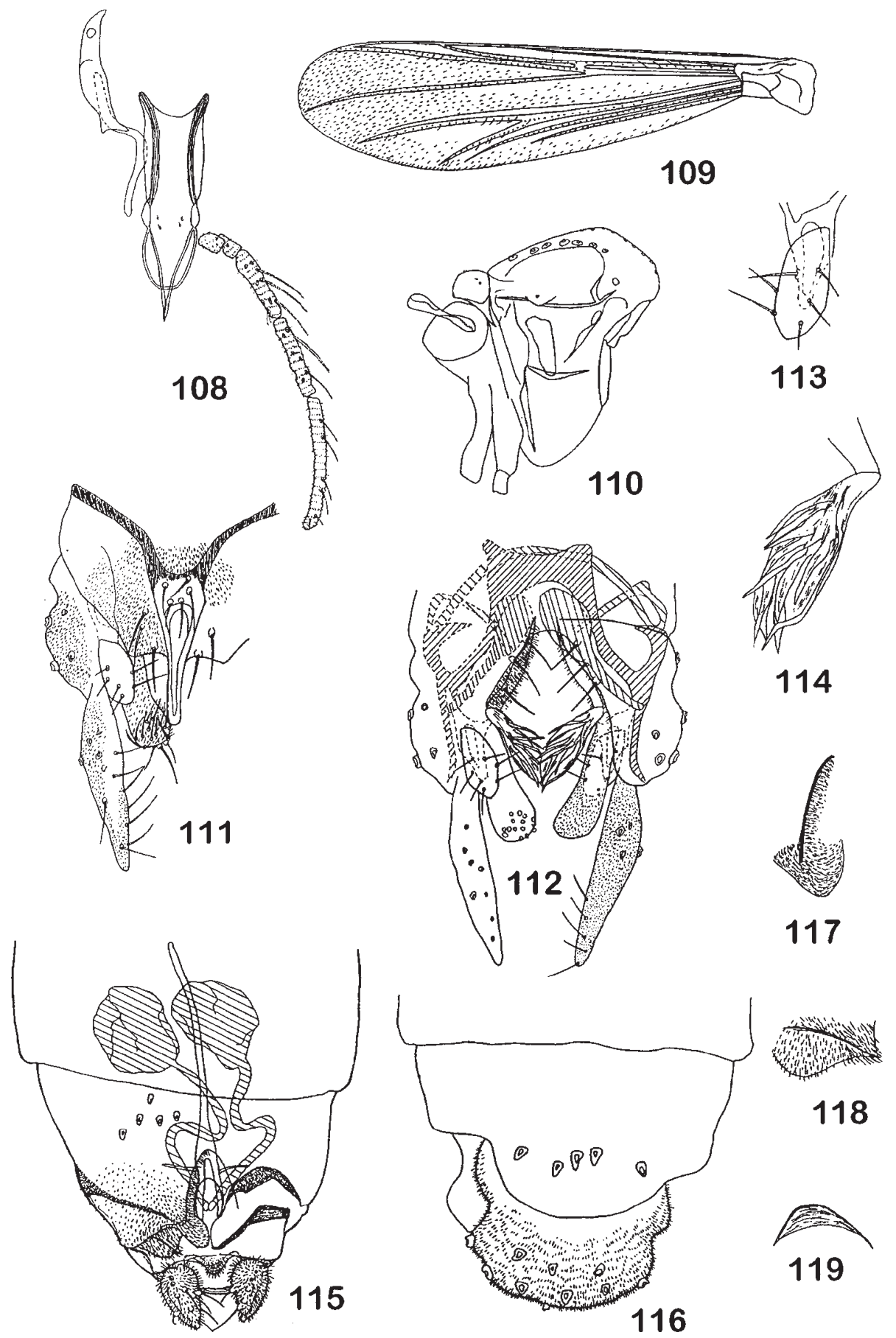

Figs. 108-119. Rheotanytarsus ceratophylli Dejoux, male and female imago. - 108, cibarial pump, tentorium, stipes and palp; 109, wing; 110, thorax; 111, 112, hypopygium, dorsal and ventral view; 113, superior volsella; 114, median volsella; 115 , 116, female genitalia, dorsal and ventral view; 117, dorsomesal lobe; 118, ventrolateral lobe; 119, apodeme lobe. 
Table 13. Rheotanytarsus ceratophylli, female. Lengths (in $\mu \mathrm{m}$ ) and proportions of legs.

\begin{tabular}{cccccc} 
& $\mathrm{fe}$ & $\mathrm{ti}$ & $\mathrm{ta}_{1}$ & $\mathrm{ta}_{2}$ & $\mathrm{ta}_{3}$ \\
\hline $\mathrm{p}_{1}$ & $336-520,384$ & $176-248,203$ & $424(1)$ & - & - \\
$\mathrm{p}_{2}$ & $360-520,406$ & $288-408,327$ & $176-192(3)$ & $88(3)$ & $56-64(3)$ \\
$\mathrm{p}_{3}$ & $360-536,428$ & $288-504,388$ & $160-272,213(5)$ & $80(1)$ & - \\
\hline & $\mathrm{ta}_{4}$ & $\mathrm{ta}_{5}$ & $\mathrm{LR}$ & $\mathrm{BV}$ & $\mathrm{SV}$ \\
\hline $\mathrm{p}_{1}$ & - & - & $1.96(1)$ & - & $1.39(1)$ \\
$\mathrm{p}_{2}$ & $40(3)$ & $32(3)$ & $0.46-0.54(3)$ & $3.89-4.59(3)$ & $3.95-4.23(3)$ \\
$\mathrm{p}_{3}$ & - & - & $0.52-0.63,0.57(5)$ & $3.37(1)$ & $4.05(1)$ \\
\hline
\end{tabular}

tae. Cells $\mathrm{m}$ with 11 setae, $\mathrm{r} 4+5$ with about 100 , $\mathrm{m} 1+2$ with about $100, \mathrm{~m} 3+4$ with about 30 , cu with about 15 and an with 15 setae.

Legs. Spur of front tibia 10-14, $11 \mu \mathrm{m}$ long; spurs of middle tibia 8-12, 9 and 10-20, $12 \mu \mathrm{m}$ long; of hind tibia 8-14, 11 and 12-20, 14 (7) $\mu \mathrm{m}$ long; all excluding comb. Combs 10-12, $11 \mu \mathrm{m}$ long. Width at apex of front tibia 28-36, $31 \mu \mathrm{m}$ long; of middle tibia 24-32, $28 \mu \mathrm{m}$ long; of hind tibia 30-40, $32 \mu \mathrm{m}$ long. Lengths and proportions of legs see table 13.

Abdomen. Number of setae on tergites could not be counted due to folding of parts of the abdomen. Likewise number of setae on sternites could not be counted.

Genitalia (figs. 115-119). Gonocoxite without setae. Tergite IX with 15-20, 18 (6) setae. Cercus 3858, $43 \mu \mathrm{m}$ long; 24-10, $6 \mu \mathrm{m}$ wide at apex. Seminal capsule 44-68, $56 \mu \mathrm{m}$ long including 6-12, 7 (7) mm long neck; seminal capsule not sclerotized. Notum 94-146, $122 \mu \mathrm{m}$ long.

Distribution. - The species is known from Senegal, a water reservoir in southern Ghana, Chad, Sudan and Nigeria.

\section{The ororus group}

The known pupae have anterior rugulose frontal apotome; thoracic horn with median bend, with points in apical $2 / 3-3 / 4$; tergites II-V with paired anterior circular patches of spines; the caudal hooklets of tergite II occupy less than the median third; and the anal lobe has a hair-like seta.

In the males the anal tergite has medially joined basal tergite bands in $R$. beccus and $R$. pallidus and, in addition, V-shaped bands which are medially joined in $R$. atrius and $R$. kjaerandseni; and there are at least some median setae between or just posterior of bands; the anal point has a basally rounded crest; the superior volsella is rounded with reduced digitus; the median volsella reaches the apex of the superior volsella and sometimes the apex of the inferior volsella; and the gonostylus is not abruptly tapered.

\section{Rheotanytarsus ororus Lehmann}

(figs. 120-131)

Rheotanytarsus ororus Lehmann 1979: 64.

Material examined. - D. R. CONGO: NE D. R. Congo, Kalengo, 1 o, 1 pupal exuviae and 1 larva, 20 x 1972, J. Lehmann (ZSM No. E1/1980)

Diagnostic characters. - See keys.

\section{Male imago $(n=1)$}

Total length not measurable. Wing length 1.12 mm. Wing length / length of profemur 1.79. Thorax with dark brown vittae and postnotum, abdomen pale, legs pale with apical $1 / 4$ of femur darker.

Head. AR 0.45. Thirteenth flagellomere $219 \mu \mathrm{m}$ long. Temporal setae absent. Clypeus with 18 setae. Tentorium $80 \mu \mathrm{m}$ long, $14 \mu \mathrm{m}$ wide at sieve pore, 8 $\mathrm{mm}$ wide at posterior tentorial pit. Stipes $108 \mu \mathrm{m}$ long, $20 \mu \mathrm{m}$ wide. Palpomere lengths (in $\mu \mathrm{m}$ ): 30,34 , 92, 96, 166. Fifth palpomere / third palpomere 1.80 .

Thorax. Dorsocentrals 12, acrostichals 18. Scutellum with 4 setae.

Wing. VR 1.73. R with 20 setae, $\mathrm{R} 1$ with $35, \mathrm{R} 4+5$ with 72 setae, Sc, RM and M bare, $M 1+2$ with 63,

Table 14. Rheotanytarsus ororus male. Lengths (in $\mu \mathrm{m}$ ) and proportions of legs.

\begin{tabular}{|c|c|c|c|c|c|c|c|c|c|c|c|}
\hline & fe & $\mathrm{ti}$ & $\mathrm{ta}_{1}$ & $\mathrm{ta}_{2}$ & $\mathrm{ta}_{3}$ & $\mathrm{ta}_{4}$ & $\mathrm{ta}_{5}$ & LR & BV & SV & $\mathrm{BR}$ \\
\hline $\mathrm{p}_{1}$ & 624 & 312 & 728 & 328 & 256 & 200 & 96 & 2.33 & 1.89 & 1.29 & 3.3 \\
\hline $\mathrm{p}_{2}$ & 600 & 440 & 256 & 120 & 88 & 64 & 48 & 0.58 & 4.05 & 4.06 & 5.0 \\
\hline $\mathrm{p}_{3}$ & 616 & 528 & 352 & 200 & 168 & 120 & 56 & 0.67 & 2.75 & 3.25 & 5.4 \\
\hline
\end{tabular}




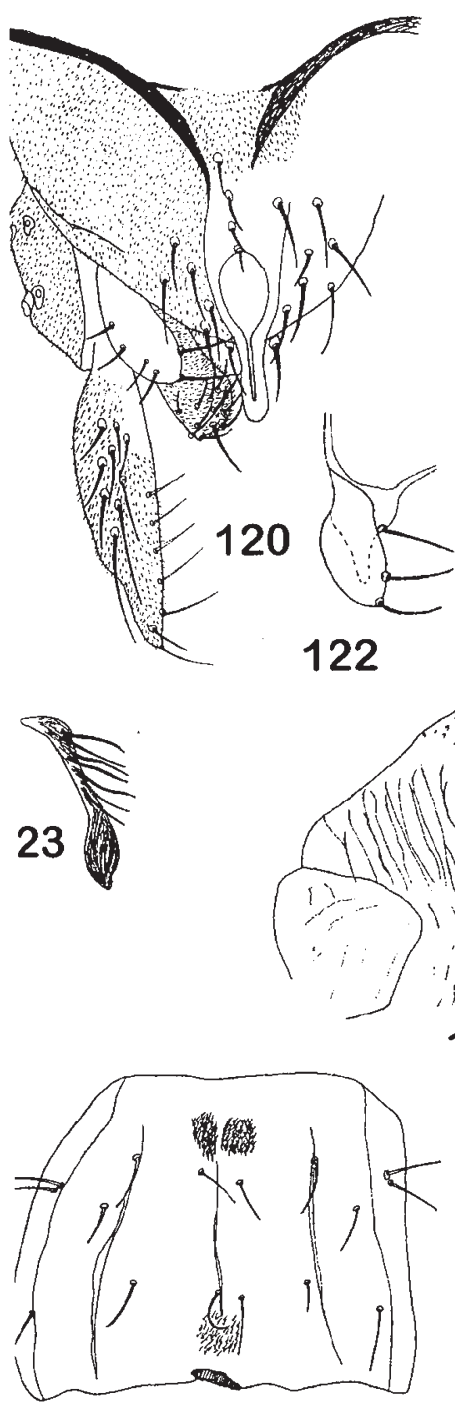

127

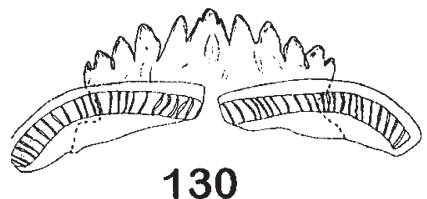

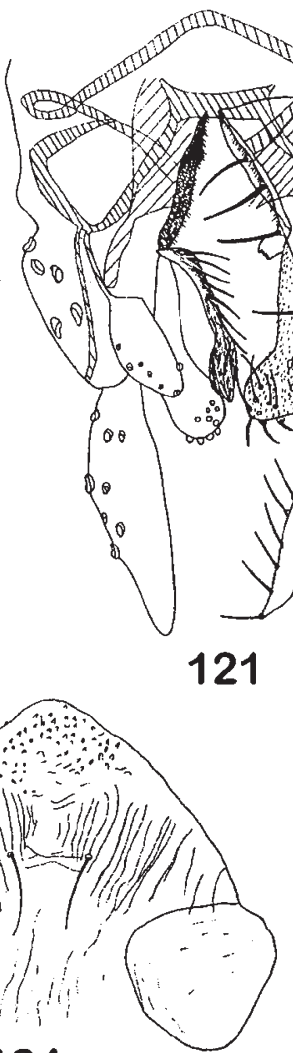

124

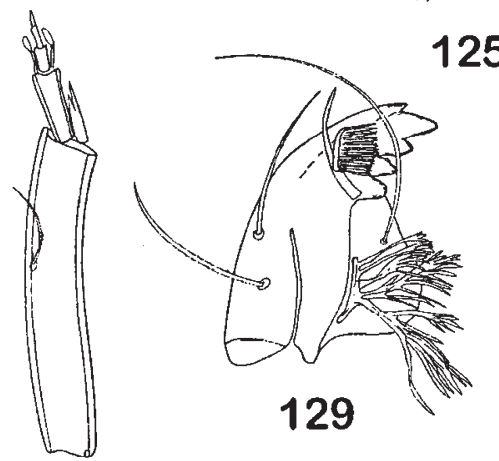

128

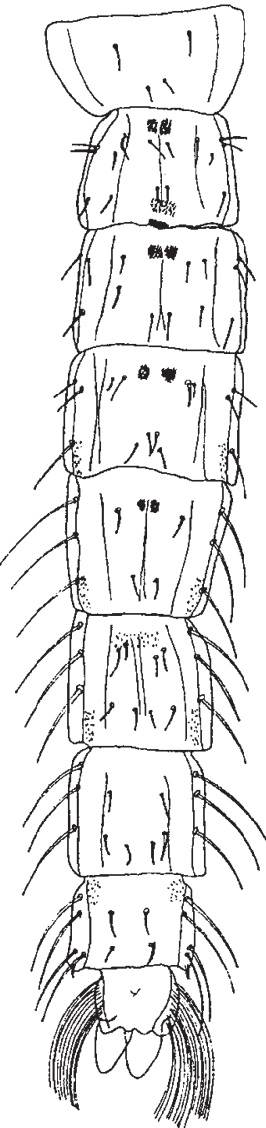

126

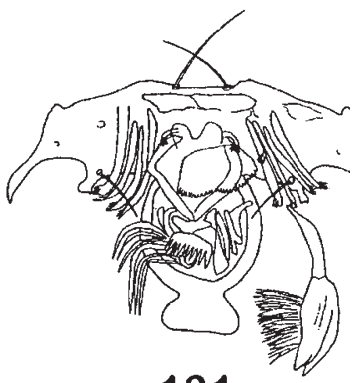

131

Figs. 120-131. Rheotanytarsus ororus Lehmann, male imago, pupa and fourth instar larva. - 120, 121, hypopygium, dorsal and ventral view; 122, superior volsella; 123 , median volsella; 124 , frontal apotome of pupa; 125 , thoracic horn; 126 , tergites I-IX; 127, tergite II; 128, larval antenna; 129, mandible; 130, mentum; 131, pecten epipharyngis. 
M3+4 with 33, Cu with 21, Cu1 with 17 , PCu with 57 and An with 35 setae. Cells $\mathrm{m}$ with 8 setae, r4+5 with about $300, \mathrm{~m} 1+2$ with about $250, \mathrm{~m} 3+4$ with about 150 , cu with 70 , and an with 70 setae.

Legs. Spur of front tibia $14 \mu \mathrm{m}$ long, spurs of middle tibia 10 and $12 \mu \mathrm{m}$ long; of hind tibia 10 and 12 $\mu \mathrm{m}$ long, all excluding comb. Combs 10-12 $\mu \mathrm{m}$ long. Width at apex of front tibia $38 \mu \mathrm{m}$, of middle tibia 30 $\mu \mathrm{m}$, of hind tibia $38 \mu \mathrm{m}$. Lengths and proportions of legs see table 14 .

Hypopygium (figs. 120-123). Tergite IX with 16 setae. Anal point $76 \mu \mathrm{m}$ long, $22 \mu \mathrm{m}$ wide at base; $6 \mu \mathrm{m}$ wide at apex; crest rounded, basally closed. Laterosternite IX with 1 seta. Phallapodeme $78 \mu \mathrm{m}$ long, transverse sternapodeme $34 \mu \mathrm{m}$ long. Gonocoxite $100 \mu \mathrm{m}$ long, gonostylus $92 \mu \mathrm{m}$ long. Superior volsella (fig. 122) $40 \mu \mathrm{m}$ long, oval; inferior volsella $60 \mu \mathrm{m}$ long; median volsella (fig. 123) $52 \mu \mathrm{m}$ long, long and clublike, with distal lamellae fused into plate with terminal points. Inferior volsella with microtrichia, superior and median volsella without microtrichia. HR 1.09.

\section{Pupa $(\mathrm{n}=1)$}

Total length $2.96 \mathrm{~mm}$. Exuviae pale with outer edges of cephalothorax dark.

Cephalothorax. Frontal apotome (fig. 124) slightly granulose anteriorly. Frontal setae $40 \mu \mathrm{m}$ long. Thoracic horn (fig. 125) $560 \mu \mathrm{m}$ long, $32 \mu \mathrm{m}$ wide, with fine spinules for most of its length. Median antepronotals $210 \mu \mathrm{m}$ long; lateral antepronotals $30 \mu \mathrm{m}$ long; both median and lateral antepronotals taeniate. Precorneals taeniate, close together, anterior precorneals $50 \mu \mathrm{m}$ long, median precorneals $64 \mu \mathrm{m}$ long, posterior precorneals $212 \mu \mathrm{m}$ long. Anterior dorsocentrals Dc1 $24 \mu \mathrm{m}$ long, Dc2 $36 \mu \mathrm{m}$ long, Dc3 20 $\mu \mathrm{m}$ long, Dc4 $20 \mu \mathrm{m}$ long. Dc1 $2 \mu \mathrm{m}$ in front of Dc2, Dc2 $94 \mu \mathrm{m}$ in front of Dc3, and Dc3 $2 \mu \mathrm{m}$ in front of Dc4. Nose of wing sheath $32 \mu \mathrm{m}$ long.

Abdomen (fig. 126). Tergite I bare; spines on tergites II-V arranged in circular patches. Tergite II (fig. 127) with additional patch of very fine spinules posteriorly. Median shagreen essentially absent, weak and sparse shagreen present caudolaterally on tergites IV and V. Number of spines on T II-V 40,40, 40, 30. Caudal hooklets occupying approximately median 1 / 7 of tergite II, about 30 hooklets. Caudal spur $14 \mu \mathrm{m}$ long. L-setae on segments II-VIII as 2, 2, 3, 3, 3, 3, 4; all taeniate on segments V-VIII, 1 taeniate and two hair-like on IV, all hair-like on III and II. Lengths of L3 and L4 on segment VIII $90 \mu \mathrm{m}$ and $100 \mu \mathrm{m}$. Anal lobe with 1 weak dorsolateral seta not always apparent; 17 taeniae in fringe; longest taeniae $280 \mu \mathrm{m}$ long. Male genital sac overreaches anal lobe by $70 \mu \mathrm{m}$.

\section{Fourth instar larva $(\mathrm{n}=1)$}

Total length $2.53 \mathrm{~mm}$. Head capsule length $0.39 \mathrm{~mm}$.

Head. Antenna as in fig. 128. Length of antennal segments (in $\mu \mathrm{m}$ ) 92, 22, 6, 4, 4. AR 2.55. Basal antennal segment $18 \mu \mathrm{m}$ wide, distance from base to ring organ $2 \mu \mathrm{m}$, to basal mark of seta $52 \mu \mathrm{m}$. Blade $18 \mu \mathrm{m}$ long; accessory blade 6-10, $8 \mu \mathrm{m}$ long. Apical style of second segment $8 \mu \mathrm{m}$ long; Lauterborn organ $6 \mu \mathrm{m}$ long, pedicel $6 \mu \mathrm{m}$ long. Pecten epipharyngis (fig. 131) a simple broad comb without indication of division into parts. Posterior chaetulae laterales with conspicuously long branches. Premandible $56 \mu \mathrm{m}$ long. Mandible (fig. 129) $110 \mu \mathrm{m}$ long. Mentum (fig. 130) $80 \mu \mathrm{m}$ wide, with median tooth $12 \mu \mathrm{m}$ wide, with lateral notches which may be more or less worn down, ventromental plate width / length 3.40, number of ventromental plate striations 23. Postmentum $106 \mu \mathrm{m}$ long.

Abdomen. Procercus $24 \mu \mathrm{m}$ long, $16 \mu \mathrm{m}$ wide, anal setae $402 \mu \mathrm{m}$ long. Supra-anal seta $112 \mu \mathrm{m}$ long; length of supra-anal setae / length of anal setae 0.28. Posterior parapods $60 \mu \mathrm{m}$ long. Anal tubuli not observable.

Distribution. - The species is known only from North Eastern D. R. Congo.

\section{Rheotanytarsus atrius sp. $\mathrm{n}$.}

(figs. 132-135)

Type locality. - GHANA: Western Region, Ankasa Game production Reserve.

Type material. - Holotype 0 , GHANA: Western Region, Ankasa Game production Reserve, $10-12$ xii 1993, light trap, NUFU project (ZMBN Type No. 320). Paratypes: $15 \hat{\delta}$, as holotype; Ghana: Eastern Region, Boti Falls, 10, $28 \mathrm{x}-4$ xi 1994, Malaise trap, NUFU project (ZMBN).

Diagnostic characters. - See key.

Etymology. - From the Twi atre meaning spoon, referring to the teaspoon - like shape of the median volsella and the suffix - us denoting the gender of the genus.

\section{Male imago $(\mathrm{n}=9-10)$}

Total length $1.43-1.63,1.53 \mathrm{~mm}$. Wing length 0.85-0.97, $0.93 \mathrm{~mm}$. Total length / wing length 1.56-1.76, 1.65. Wing length / length of profemur 1.92-2.09, 2.01. Thorax, abdomen and legs pale.

Head. AR 0.20-0.25, 0.22. Thirteenth flagellomere 86-111, $97 \mu \mathrm{m}$ long. Temporal setae 5-7, 6; including 2-3, 3 inner verticals; 2 outer verticals; and 1-2, 2 postorbitals. Clypeus with 14-17, 15 setae. Tentorium 33-58, $51 \mu \mathrm{m}$ long; $11-20,13 \mu \mathrm{m}$ wide at sieve pore; 7-9, $9 \mu \mathrm{m}$ wide at posterior tentorial pit. Stipes 64-78, 

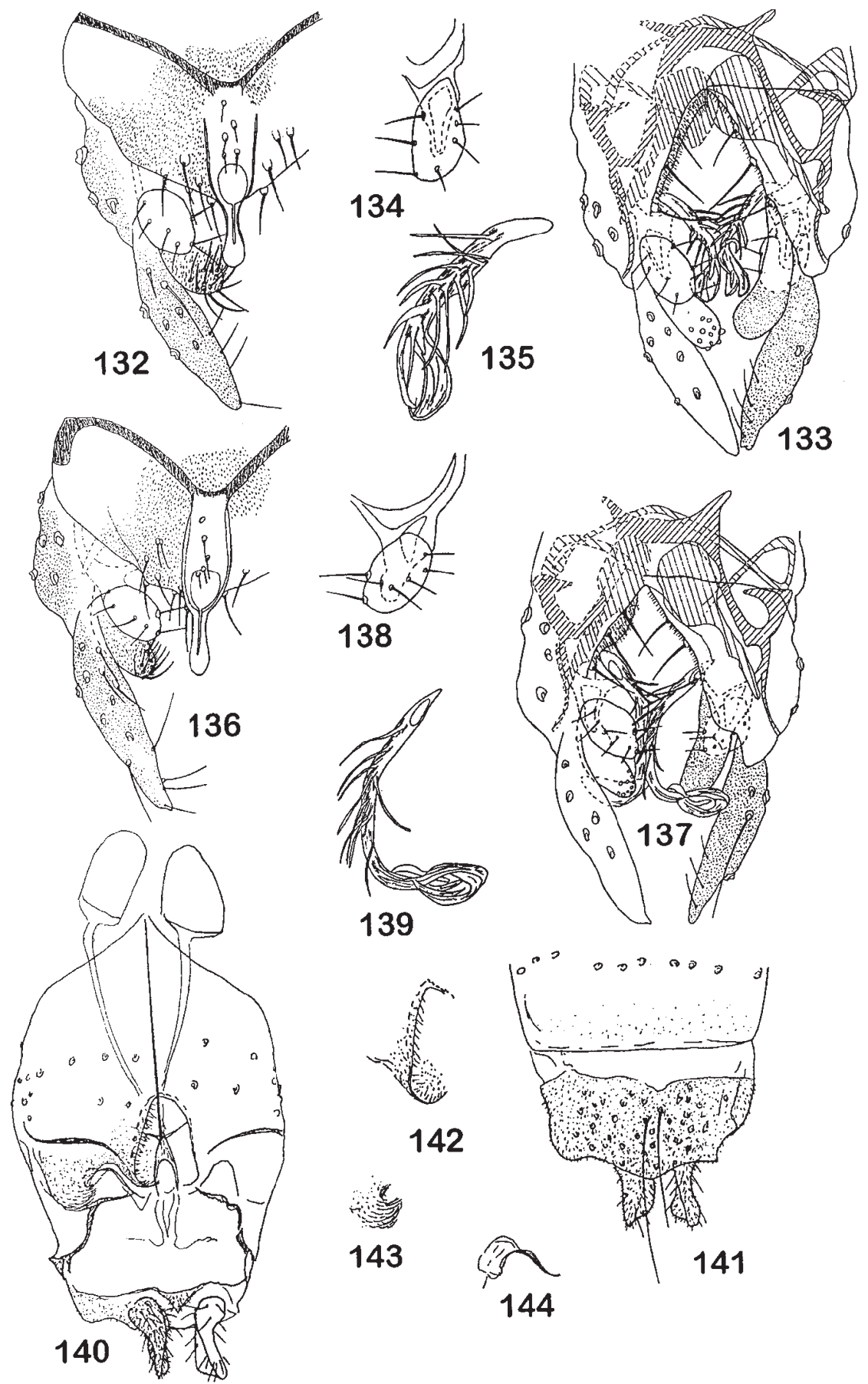

Figs. 132-135. Rheotanytarsus atrius sp. n., male imago. - 132, 133, hypopygium, dorsal and ventral view; 134, superior volsella; 135 , median volsella.- figs. 136-144. R. kjaerandseni sp. n., male and female imago. $-136,137$, hypopygium, dorsal and ventral view; 138, superior volsella; 139, median volsella; 140, 141, female genitalia, ventral and dorsal view; 142, dorsomesal lobe; 143 , ventrolateral lobe; 144 , apodeme lobe. 
Table 15. Rheotanytarsus atrius, male. Lengths (in $\mu \mathrm{m}$ ) and proportions of legs.

\begin{tabular}{|c|c|c|c|c|c|c|}
\hline & $\mathrm{fe}$ & $\mathrm{ti}$ & $\mathrm{ta}_{1}$ & $\mathrm{ta}_{2}$ & $\mathrm{ta}_{3}$ & $\mathrm{ta}_{4}$ \\
\hline $\mathrm{p}_{1}$ & $443-496,468$ & $200-221,211$ & $575-643,614$ & $271-314,294$ & $200-225,214$ & $157-182,172$ \\
\hline $\mathrm{p}_{2}$ & $343-503,453$ & $250-350,324$ & $146-182,169$ & $57-86,79$ & $46-68,61$ & $32-43,40$ \\
\hline \multirow[t]{2}{*}{$\mathrm{p}_{3}$} & $464-525,491$ & $364-400,381$ & $218-250,235$ & $129-153,143$ & $118-132,25$ & $82-96,90$ \\
\hline & $\mathrm{ta}_{5}$ & LR & BV & SV & $\mathrm{BR}$ & \\
\hline $\mathrm{p}_{1}$ & $71-89,81$ & $2.75-3.05,2.89$ & $1.65-1.74,1.70$ & $1.07-1.18,1.11$ & $2.6-3.6,3.1$ & \\
\hline $\mathrm{p}_{2}$ & $25-36,31$ & $0.50-0.58,0.52$ & $4.32-4.69,4.51$ & $4.05-4.79,4.59$ & $4.6-7.1,5.6$ & \\
\hline $\mathrm{p}_{3}$ & $43-57,49$ & $0.57-0.66,0.61$ & $2.64-2.84,2.72$ & $3.49-3.98,3.74$ & $5.7-7.6,6.4$ & \\
\hline
\end{tabular}

$71 \mu \mathrm{m}$ long; 4-11, $7 \mu \mathrm{m}$ wide. Palpomere lengths (in $\mu \mathrm{m}): 22-27,24 ; 18-24,21 ; 44-55,53 ; 53-87,62$; $100-120,111$. Fifth palpomere / third palpomere 1.88-2.41, 2.14.

Thorax. Dorsocentrals 8-10, 9; acrostichals 12-16, 14. Scutellum with 3-5, 4 setae.

Wing. VR 1.60-1.69, 1.65. R with 9-13, 11 setae; R1 with 11-17, 14; R4+5 with 34-43, 40; Sc and M bare; RM with $0-2,1$; M1+2 with 33-45, 38; M3+4 with 16-22, 19; Cu with 10-15, 12; Cu1 with 10-14, 12; PCu with 26-38, 32; and An with 17-21, 19 setae. Cells $\mathrm{m}$ with $11-19$, 15 setae; $\mathrm{r} 4+5$ with about $300 ; \mathrm{m} 1+2$ with about $250 ; \mathrm{m} 3+4$ with $36-66,49 ; \mathrm{cu}$ with 43-69, 54; and an with 9-18, 13 setae.

Legs. Spur of front tibia 18-24, $20 \mu \mathrm{m}$ long; spurs of middle tibia 4-11, 8 and 11-13, $12 \mu \mathrm{m}$ long; of hind tibia 9-15, 13 and 11-18, $15 \mu \mathrm{m}$ long, all excluding comb. Comb of middle tibia 9-13, $11 \mu \mathrm{m}$ long; of hind tibia $11-15,13 \mu \mathrm{m}$ long. Width at apex of front tibia 29-33, $31 \mu \mathrm{m}$; of middle tibia 24-31, 27 $\mu \mathrm{m}$; of hind tibia $29-40,31 \mu \mathrm{m}$. Lengths and proportions of legs see table 15.

Hypopygium (figs. 132-135). Tergite IX with 914, 11 setae. Anal point 42-62, $53 \mathrm{~mm}$ long, 15-22, $18 \mu \mathrm{m}$ wide at base; 4-9, $7 \mu \mathrm{m}$ wide at apex; crest rounded and basally closed. Laterosternite IX with 12, 1 setae. Phallapodeme 44-58, $50 \mathrm{~mm}$ long; transverse sternapodeme 29-38, $34 \mathrm{~mm}$ long. Gonocoxite 64-71, 68 mm long; gonostylus 58-67, $63 \mathrm{~mm}$ long. Superior volsella (fig. 134) 22-31, $27 \mathrm{~mm}$ long, ovoid; inferior volsella 42-51, $48 \mathrm{~mm}$ long; median volsella (fig. 135) 38-44, $42 \mathrm{~mm}$ long, strongly Sshaped, with distal lamelliform setae fused into single plate without apical points. Inferior volsella with microtrichia, superior and median volsellae without microtrichia. HR 1.07-1.15, 1.10; HV 2.31-2.72, 2.32.

Distribution. - The species is known only from two rivers in southern Ghana.

\section{Rheotanytarsus kjaerandseni sp. n.} (figs. 136-155)

Type locality. - GHANA: Volta Region, Wli, Agumatsa Waterfalls.

Type material. - Holotype $\widehat{\sigma}$, GHANA: Volta Region, Wli, Agumatsa Waterfalls, 17-20 xi 1993, Malaise trap loc. 5, NUFU project.(ZMBN Type No. 321). - Paratypes: $1 \hat{\sigma}$, as holotype; $1 \hat{0}$, except 4-13 iii 1993, 10 , except 10-13 iii 1993, $3 \hat{0}$, reared from pupa, 1 reared from pupa, 10 pupal exuviae, 13 larvae, as holotype except 12 xii 1993, drift sample station 1, NUFU project; Western Region, Ankasa Game

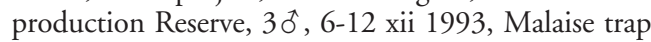
loc. 1, NUFU project; Western Region, Ankasa Game production Reserve, 30े, 10-12 xii 1993, light trap, NUFU project; Eastern Region, Kibi, Subri River, 10 , 4 ii 1993, light trap, NUFU project; Central Region, Kakum Forest Reserve, $11 \sigma^{\hat{0}, ~ 8-18 ~ x i ~ 1994, ~ M a l a i s e ~}$ trap, NUFU project (ZMBN, ZSM, BMNH, RMB)

Diagnostic characters. - See keys.

Etymology. - Named after the collector of the holotype.

\section{Male imago $(n=10)$}

Total length 1.56-2.34, $1.82 \mathrm{~mm}$. Wing length 0.90-1.11, $0.96 \mathrm{~mm}$. Total length/ wing length 1.69$1.84,1.77$. Wing length / length of profemur 1.671.98, 1.84. Thorax including postnotum dark brown, abdomen pale, legs pale brown.

Head. AR 0.16-0.36, 0.25. Thirteenth flagellomere 71-178, $112 \mu \mathrm{m}$ long. Temporal setae 6-7, 7; including 2-3, 3 inner verticals; 2-3, 2 outer verticals; 1-2, 2 postorbitals. Clypeus with 14-19, 17 setae. Tentorium 49-73, $61 \mu \mathrm{m}$ long; 11-20, $15 \mu \mathrm{m}$ wide at sieve pore; and 9-11, $9 \mu \mathrm{m}$ wide at posterior tentorial pit. Stipes 66-89, $78 \mu \mathrm{m}$ long; 4-11, $7 \mu \mathrm{m}$ wide. Palpomere lengths (in $\mu \mathrm{m}$ ): 20-27, 24; 20-29, 24; 5371, 62; 53-71, 64; 118-154, 134. Fifth palpomere / third palpomere 1.90-2.41, 2.16 .

Thorax. Dorsocentrals 9-12, 11; acrostichals 1424, 18. Scutellum with 3-6, 5 setae.

Wing. VR $1.60-1.67,1.63$. R with $12-17,14$ setae; 

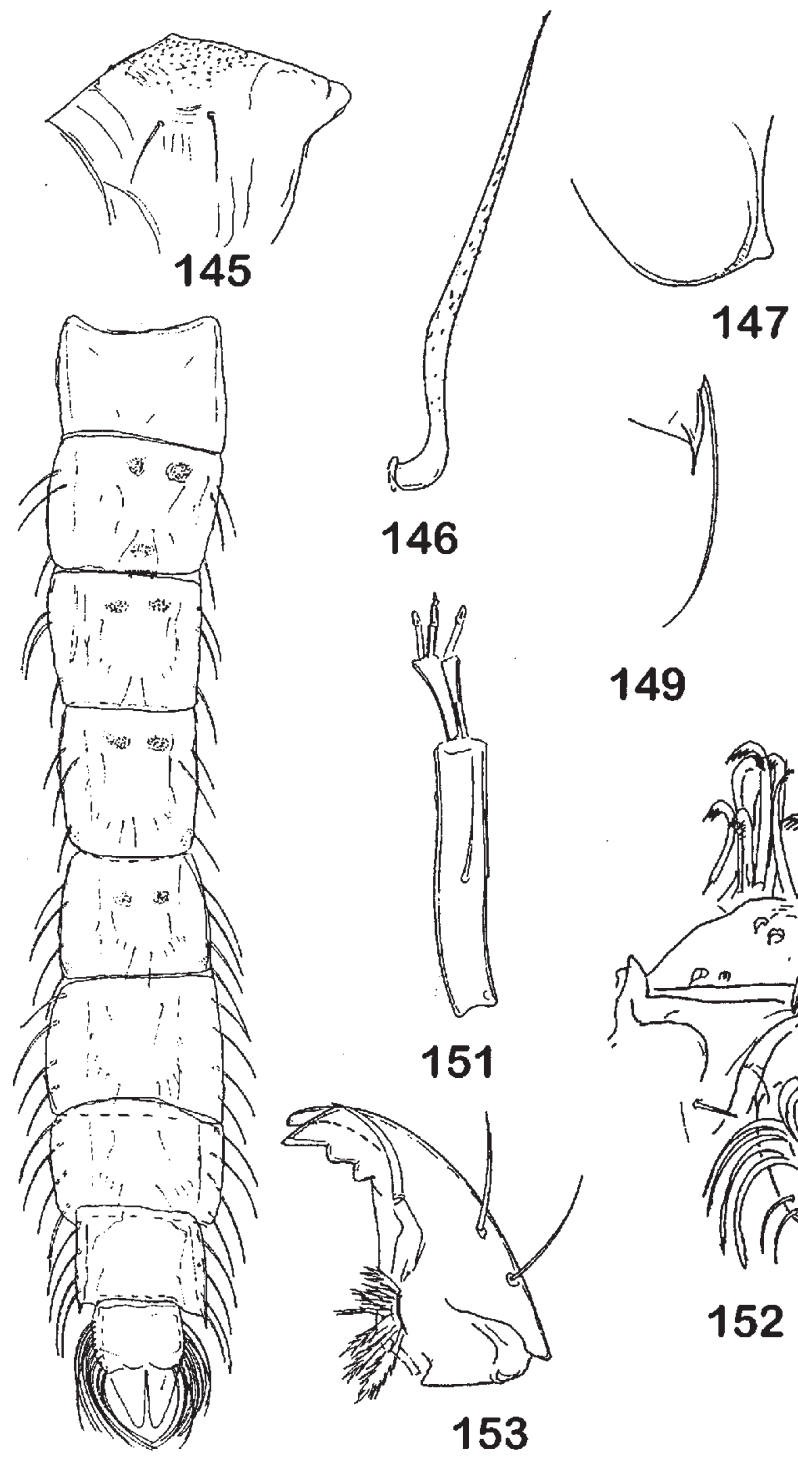

151

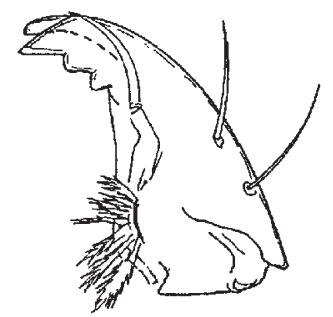

153
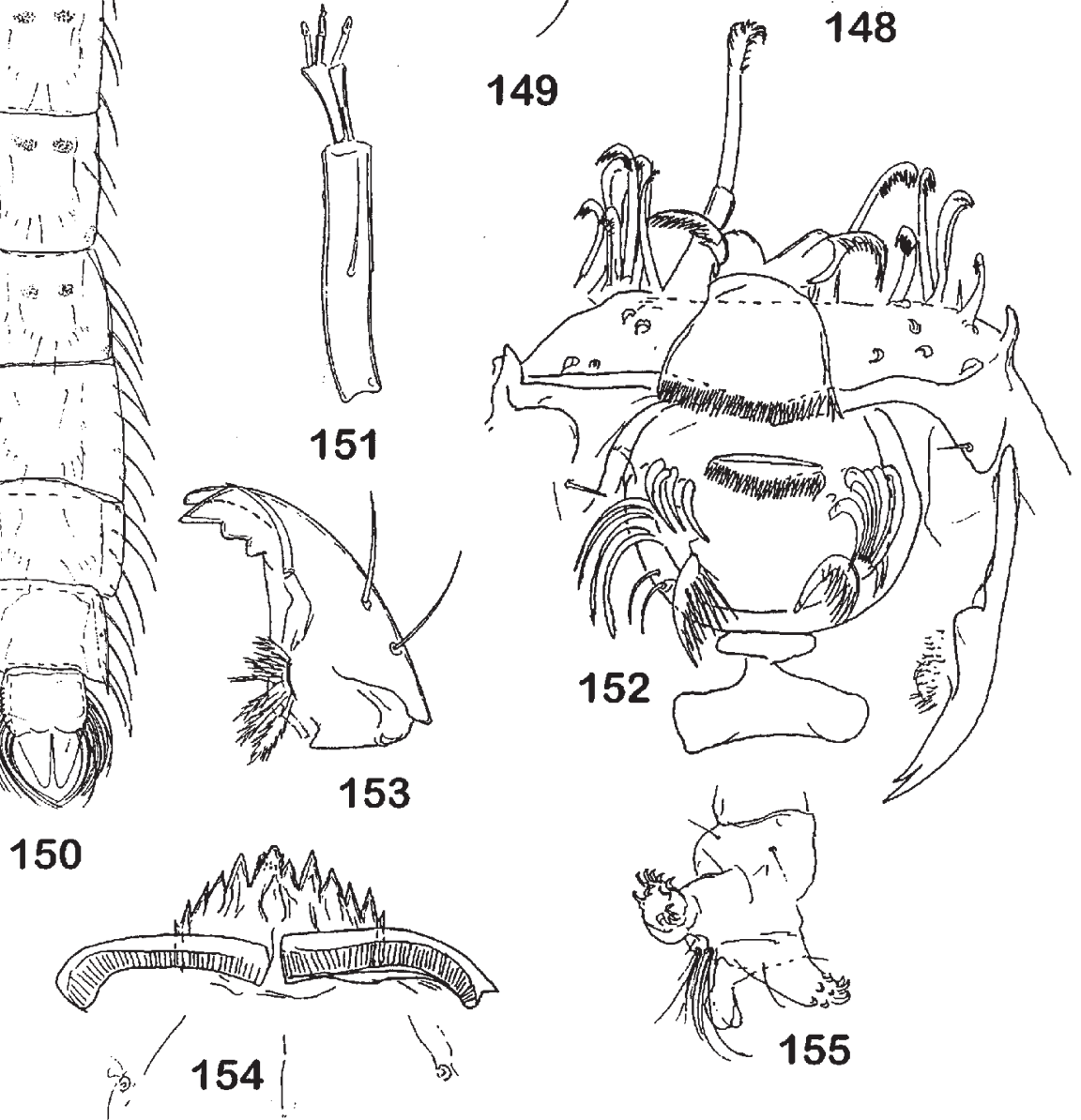

Figs. 145-155. Rheotanytarsus kjaerandseni sp. n., pupa and fourth instar larva. - 145, frontal apotome of pupa; 146, thoracic horn; 147, wing sheath nose; 148, tergite II; 149, caudal spur; 150, tergites I-IX; 151, larval antenna; 152, pecten epipharyngis; 153 , mandible; 154, mentum; 155 , posterior parapods. 
Table 16. Rheotanytarsus kjaerandseni, male. Lengths (in $\mu \mathrm{m}$ ) and proportions of legs.

\begin{tabular}{|c|c|c|c|c|c|c|}
\hline & $\mathrm{fe}$ & $\mathrm{ti}$ & $\mathrm{ta}_{1}$ & $\mathrm{ta}_{2}$ & $\mathrm{ta}_{3}$ & $\mathrm{ta}_{4}$ \\
\hline $\mathrm{p}_{1}$ & $464-653,527$ & $221-261,242$ & $578-728,656$ & $286-368,334$ & $207-260,238$ & $171-216,195$ \\
\hline $\mathrm{p}_{2}$ & $446-578,496$ & $336-418,369$ & $175-232,201$ & 75-107, 90 & $38-76,63$ & $36-52,42$ \\
\hline \multirow[t]{2}{*}{$\mathrm{p}_{3}$} & $482-586,530$ & $386-482,422$ & $236-314,278$ & 132-186, 163 & $125-157,144$ & $75-111,94$ \\
\hline & $\mathrm{ta}_{5}$ & LR & BV & SV & BR & \\
\hline $\mathrm{p}_{1}$ & $86-100,93$ & $2.47-2.80,2.61$ & $1.66-1.76,1.69$ & $1.18-1.32,1.22$ & $2.4-3.7,3.4$ & \\
\hline $\mathrm{p}_{2}$ & $32-44,36$ & $0.50-0.57,0.54$ & $4.32-5.05,4.56$ & $4.17-4.72,4.35$ & $4.2-5.7,5.3$ & \\
\hline $\mathrm{p}_{3}$ & $46-57,52$ & $0.61-0.66,0.64$ & $2.61-2.86,2.77$ & $3.37-3.68,3.50$ & $5.0-7.9,6.1$ & \\
\hline
\end{tabular}

R1 with 17-25, 20; R4+5 40-58, 47; Sc bare; RM with 1-2, 2; M with $0-2,0$; M1+2 with 36-60, 43; M3+4 with 17-23, 21; Cu with 13-17, 14; Cu1 with 12-16, 14; $\mathrm{PCu}$ with 40-56, 45; and An with 19-24, 21 setae. Cells $\mathrm{m}$ with $20, \mathrm{r} 4+5$ with about 300 , $\mathrm{m} 1+2$ with about $300, \mathrm{~m} 3+4$ with 100 , and an with 50 setae.

Legs. Spurs of front tibia 15-22, $20 \mu \mathrm{m}$ long; spurs of middle tibia 7-11, 9 and 11-15, $13 \mu \mathrm{m}$ long; of hind tibia 13-18, 14 and 15-20, $16 \mu \mathrm{m}$ long; all excluding comb. Combs 9-13, $12 \mu \mathrm{m}$ long. Width at apex of front tibia $31-38,34 \mu \mathrm{m}$; of middle tibia 2935, $31 \mu \mathrm{m}$; of hind tibia 31-44, $35 \mu \mathrm{m}$. Lengths and proportions of legs see table 16.

Hypopygium (figs. 136-139). Tergite IX with 8-14, 10 setae. Anal point 35-69, $55 \mu \mathrm{m}$ long; 18-24, $21 \mu \mathrm{m}$ wide at base; 4-11, $9 \mu \mathrm{m}$ wide at apex; crest rounded and basally closed. Laterosternite IX with 1-2, 2 setae. Phallapodeme 35-62, $54 \mu \mathrm{m}$ long; transverse sternapodeme 31-49, $39 \mu \mathrm{m}$ long. Gonocoxite 67-89, 80 $\mu \mathrm{m}$ long; gonostylus $64-87,77 \mu \mathrm{m}$ long. Superior volsella (fig. 138) 24-35, $29 \mu \mathrm{m}$ long with narrow base, vestige of digitus conspicuous; inferior volsella 44-62, 54 um long; median volsella (fig. 139) 55-69, $60 \mu \mathrm{m}$ long, strongly curved, reaching apex of inferior volsella, apical plate pointed, turned outwards, without terminal points. Inferior volsella with microtrichia, superior and median volsellae without microtrichia. HR 1.00-1.15, 1.04; HV 2.08-2.69, 2.38.

\section{Female $(\mathrm{n}=1)$}

Total length $1.84 \mathrm{~mm}$. Wing not measurable. Thorax dark. Legs and abdomen pale.

Head. AR 0.29. Lengths of flagellomeres (in $\mu \mathrm{m}$ ):
$61,37,37,41,51$. Temporal setae 7 , including 3 inner verticals, 2 outer verticals, and 2 postorbitals. Clypeus with 24 setae. Tentorium $57 \mu \mathrm{m}$ long, 14 $\mu \mathrm{m}$ wide at sieve pore and $10 \mu \mathrm{m}$ wide at posterior tentorial pit. Stipes $88 \mu \mathrm{m}$ long, $8 \mu \mathrm{m}$ wide. Palpomere lengths (in $\mu \mathrm{m}$ ): 27, 27, 66, 70, 119. Fifth palpomere / third palpomere 1.81 .

Thorax. Dorsocentrals 16, acrostichals 24. Scutellum with 8 setae.

Legs. Spur of front tibia $20 \mu \mathrm{m}$ long, spurs of middle tibia 10 and $14 \mu \mathrm{m}$ long, of hind tibia 14 and 16 $\mu \mathrm{m}$ long, all excluding comb. Comb of middle tibia 8 $\mu \mathrm{m}$ long, of hind tibia $16 \mu \mathrm{m}$ long. Width at apex of front tibia $37 \mu \mathrm{m}$, of middle tibia $35 \mu \mathrm{m}$, of hind tibia $41 \mathrm{~mm}$. Lengths and proportions of legs see table 17.

Abdomen. Number of setae on tergites I-VIII as: 69, 6-8, 7-9, 6-10, 6-10, 6-9, 6-9, 5-10. Number of setae on sternites I-VII as: 0, 2-3, 2-4, 2-6, 2-4, 3-4, 34. On sternite VIII $10-15$ setae, 3-6 on each side of the genital fissure and 1-3 along lateral margin.

Genitalia (figs. 140-144). Gonocoxite without setae. Tergite IX with 41 setae. Cercus $55 \mu$ m long, 6 $\mu \mathrm{m}$ wide at apex. Seminal capsule $55 \mu \mathrm{m}$ long including $14 \mu \mathrm{m}$ long neck, seminal capsule not sclerotized. Notum $76 \mu \mathrm{m}$ long.

\section{Pupa $(\mathrm{n}=10)$}

Total length 1.88-2.42, $2.26 \mathrm{~mm}$. Exuviae pale with outer edges of cephalothorax dark.

Cephalothorax. Frontal apotome (fig. 145) slightly granulose anteriorly. Frontal setae 18-43, $27 \mu \mathrm{m}$ long. Frontal apotome rugulose anteriorly. Thoracic horn (fig. 146) 340-444, $392 \mu \mathrm{m}$ long; 28-44, $37 \mu \mathrm{m}$ wide; with fine spinules for most of its length. Median an-

Table 17. Rheotanytarsus kjaerandseni, female. Lengths (in $\mu \mathrm{m}$ ) and proportions of legs.

\begin{tabular}{ccccccccccc} 
& $\mathrm{fe}$ & $\mathrm{ti}$ & $\mathrm{ta}_{1}$ & $\mathrm{ta}_{2}$ & $\mathrm{ta}_{3}$ & $\mathrm{ta}_{4}$ & $\mathrm{ta}_{5}$ & $\mathrm{LR}$ & $\mathrm{BV}$ & $\mathrm{SV}$ \\
\hline $\mathrm{p}_{1}$ & 480 & 208 & 500 & 28 & 200 & 180 & 96 & 2.40 & 1.57 & 1.38 \\
$\mathrm{p}_{2}$ & 472 & 280 & 200 & 100 & 68 & 48 & 40 & 0.71 & 3.72 & 3.76 \\
$\mathrm{p}_{3}$ & 500 & 440 & 240 & 160 & 144 & 96 & 68 & 0.54 & 2.52 & 3.92 \\
\hline
\end{tabular}



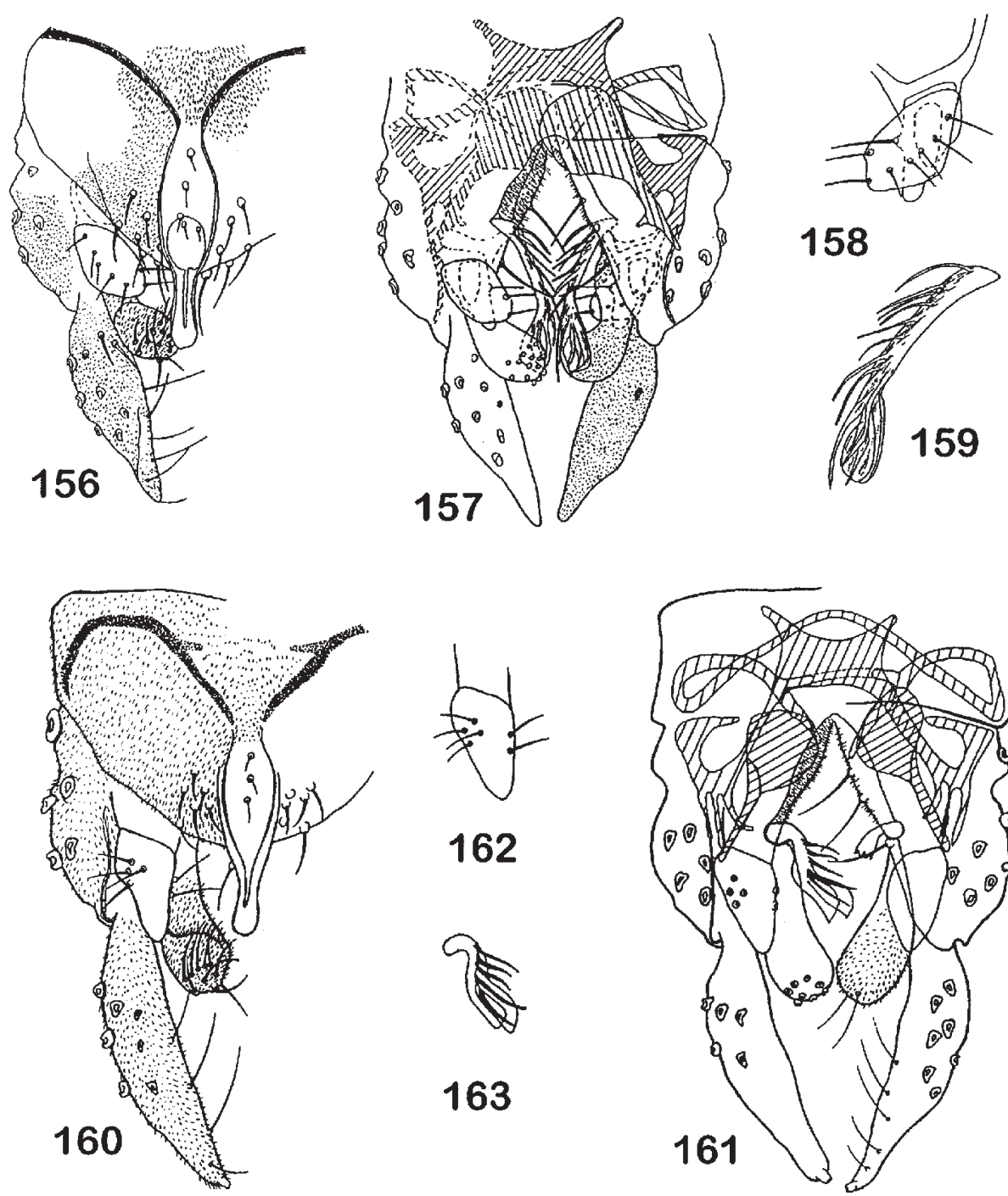

163

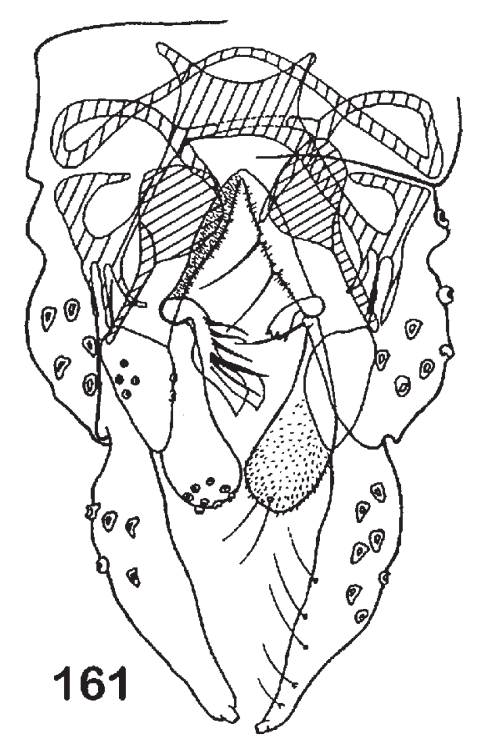

Figs. 156-159. Rheotanytarsus digitatus sp. n., male imago. - 156, 157, hypopygium, dorsal and ventral view; 158, superior volsella; 159 , median volsella. - figs. 160-163. R. jongkindi sp. n., male imago. - 160, 161, hypopygium, dorsal and ventral view; 162, superior volsella; 163 , median volsella. 
tepronotals 82-143, $110 \mu \mathrm{m}$ long; lateral antepronotals 31-61, $45 \mu \mathrm{m}$ long; both median and lateral antepronotals taeniate. Precorneals taeniate, close together; anterior precorneals 16-49, $34 \mu \mathrm{m}$ long; median precorneals $25-72,38 \mu \mathrm{m}$ long; posterior precorneals 113-184, $149 \mu \mathrm{m}$ long. Anterior dorsocentrals Dc1 10-25, 15 um long; Dc2 10-29, $15 \mu \mathrm{m}$ long; Dc3 10-20, $14 \mu \mathrm{m}$ long; Dc4 10-16, $13 \mu \mathrm{m}$ long. Dc1 $1-2,2 \mu \mathrm{m}$ in front of Dc2; Dc2 78-96, $84 \mu \mathrm{m}$ in front of Dc3; and Dc3 1-3, $2 \mu \mathrm{m}$ in front of Dc4. Nose of wing sheath (fig. 147) 22-39, $27 \mu \mathrm{m}$ long.

Abdomen (fig. 150). Tergite I bare; spines on tergites II-V arranged in circular patches. Tergite II (fig. 148) with additional pair of posterior patches of very fine spinules. Median shagreen essentially absent, weak and sparse shagreen present caudolaterally on tergites IV and V; tergite VI with anterior shagreen. Number of spines on T II-V 50-70, 60; 50-70, 57;4060,$50 ; 27-50,39$. Caudal hooklets occupying approximately median 1 / 4 of tergite II, about 30 hooklets. Caudal spur (fig. 150) 18-31, $23 \mu \mathrm{m}$ long. L-setae on segments II-VIII as 3, 3, 3, 4, 4, 4, 4; all taeniate. Lengths (in $\mu \mathrm{m}$ ) of L3 and L4 on segment VIII: 72240, 107; 82-225, 106. Anal lobe with one weak dorsolateral seta not always apparent; $15-17,16$ taeniae in fringe: longest taeniae 340-520, $442 \mu \mathrm{m}$ long. Male genital sac overreaches anal lobe by $82-127,94 \mu \mathrm{m}$.

\section{Fourth instar larva $(\mathrm{n}=10)$}

Total length 2.20-3.14, $2.72 \mathrm{~mm}$. Head capsule length $0.22-0.26,0.24 \mathrm{~mm}$.

Head. Antenna as in fig. 151. Length of antennal segments (in $\mu \mathrm{m}$ ): 72-84, 78; 16-22, 18; 6-10, 7; 4; 2-4, 3. AR 1.85-2.73, 2.36. Basal antennal segment $12-14,13 \mu \mathrm{m}$ wide; distance from base to ring organ $3-7,5 \mu \mathrm{m}$; to basal mark of seta 35-47, $42 \mu \mathrm{m}$. Blade 14-20, $18 \mu \mathrm{m}$ long; accessory blade 6-10, $8 \mu \mathrm{m}$ long. Apical style of second segment 4-5, $4 \mu \mathrm{m}$ long; Lauterborn organ 3-7, $5 \mu \mathrm{m}$ long; pedicel 5-11, $8 \mu \mathrm{m}$ long. Pecten epipharyngis (fig. 152) a simple broad comb without indication of division into parts. Posterior chaetulae laterales with conspicuously long branches. Premandible 39-45, $42 \mu \mathrm{m}$ long. Mandible (fig. 153) 72-88, $78 \mu \mathrm{m}$ long. Mentum (fig. 154) 51$61,57 \mu \mathrm{m}$ wide; with median tooth $8-14,10 \mu \mathrm{m}$ wide, with lateral notches which may be more or less worn down; ventromental plate width / length 3.114.50, 3.56; number of ventromental plate striations 21-24, 22. Postmentum 90-96, 93 um long.

Abdomen. Procercus 16-25, $20 \mu \mathrm{m}$ long; 12-18, 15 $\mu \mathrm{m}$ wide; anal setae 260-340, $299 \mu \mathrm{m}$ long. Supra-anal seta $60-100,75 \mu \mathrm{m}$ long; length of supra-anal setae / length of anal setae $0.21-0.29,0.25$. Posterior parapods (fig. 155) 102-164, $131 \mu \mathrm{m}$ long. Anal tubuli 66154, $97 \mu \mathrm{m}$ long; 16-41, $29 \mathrm{~mm}$ wide at base; 20-55, $37 \mu \mathrm{m}$ wide at middle; $14-31,20 \mu \mathrm{m}$ wide at apex.

\section{Third instar larvae $(\mathrm{n}=3)$}

Total length 1.81-2.00 mm. Head capsule length $0.16-0.20 \mathrm{~mm}$.

Head. Length of antennal segments (in $\mu \mathrm{m}$ ): $45-$ 47, 12-16, 4-6, 4, 2. AR 1.57-1.92. Basal antennal segment $8-10 \mu \mathrm{m}$ wide, distance from base to ring organ 3-4 $\mu \mathrm{m}$, to basal mark of seta $16-20 \mu \mathrm{m}$. Blade 14-17 $\mu \mathrm{m}$ long; accessory blade 5-8 $\mu \mathrm{m}$ long. Apical style of second segment 3-4 $\mu \mathrm{m}$ long; Lauterborn organ 4-5 $\mu \mathrm{m}$ long, pedicel 4-7 $\mu \mathrm{m}$ long. Premandible 29-33 $\mu \mathrm{m}$ long. Mandible 53-61 $\mu \mathrm{m}$ long. Mentum 35-43 $\mu \mathrm{m}$ wide, with median teeth 6-8 $\mu \mathrm{m}$ wide; ventromental plate width/ length 3.50-3.80; number of ventromental plate striations 17-18 (2); postmentum 67-76 $\mu \mathrm{m}$ long.

Abdomen. Procercus 14-18 $\mu \mathrm{m}$ long, 8-10 $\mu \mathrm{m}$ wide; anal setae $140-240 \mu \mathrm{m}$ long. Supra-anal seta $44-$ $72 \mu \mathrm{m}$ long; length of supra-anal setae / length of anal setae $0.27-0.31$. Posterior parapods $76-82 \mu \mathrm{m}$ long. Anal tubuli $49-72 \mu \mathrm{m}$ long; $16-20 \mu \mathrm{m}$ wide at base, $25-31 \mu \mathrm{m}$ wide at middle, $12-20 \mu \mathrm{m}$ wide at apex.

Distribution. - The species is known from small rivers in southern Ghana.

\section{The thermae group}

$R$. kyotoensis (Tokunaga), the only species of the group with known pupa, has a bare thoracic horn without median bend, tergites II-V with paired anterior circular patches of spines, tergite II with posterior shagreen arranged into two groups, and anal lobe with hair-like dorsal seta.

The male imagines of the group have a median volsella reaching apex of inferior volsella, with setae fused into apical plate(s), superior volsella mostly rounded or occasionally with knob-like apical projection,with well developed digitus; and gonostylus usually not abruptly tapered.

\section{Rheotanytarsus digitatus sp. $\mathrm{n}$.}

(figs. 156-159)

Type locality. - GHANA: Eastern Region, Kibi, Subri River.

Type material. - Holotype o $\widehat{0}$, GHANA: Eastern Region, Kibi, Subri River; 6 xi 1993, light trap, NUFU project (ZMBN Type No. 322). Paratypes: $2 \hat{0}$, as holotype, 2 o, as holotype except 4 ii 1993; Ghana: Central Region, Kakum Forest Reserve, Abrafo, 13 $\widehat{\delta}, 8-18$ xi 1994, Malaise trap, NUFU project; 20 except Entwikrom, 8-15 xi 1994 (ZSM, BMNH, RMB).

Diagnostic characters. - See key.

Etymology.- After the Latin digitatus meaning having fingers, referring to the finger-like apical points of the median volsella. 
Table 18. Rheotanytarsus digitatus, male. Lengths (in $\mu \mathrm{m}$ ) and proportions of legs.

\begin{tabular}{lcccccc} 
& $\mathrm{fe}$ & $\mathrm{ti}$ & $\mathrm{ta}$ & $\mathrm{ta}_{2}$ & $\mathrm{ta}_{3}$ & $\mathrm{ta}_{4}$ \\
\hline $\mathrm{p}_{1}$ & $464-643,541$ & $200-293,241$ & $592-796,665$ & $280-392,335$ & $192-275,241$ & $160-232,203$ \\
$\mathrm{p}_{2}$ & $456-625,518$ & $328-446,370$ & $192-246,222$ & $88-121,100$ & $64-86,71$ & $36-50,47$ \\
$\mathrm{p}_{3}$ & $504-661,555$ & $376-536,431$ & $246-346,256$ & $143-193,162$ & $128-193,142$ & $82-114,97$ \\
\hline & \multicolumn{2}{c}{$\mathrm{ta}$} & $\mathrm{LR}$ & $\mathrm{BV}$ & $\mathrm{SV}$ & $\mathrm{BR}$ \\
\hline $\mathrm{p}_{1}$ & $56-100,81$ & $2.61-2.73,2.75$ & $1.50-1.86,1.73$ & $1.07-1.28,1.18$ & $2.7-3.0(3)$ \\
$\mathrm{p}_{2}$ & $32-40,37$ & $0.55-0.65,0.59$ & $3.93-4.82,4.46$ & $3.70-4.40,4.00$ & $3.9-7.5,5.3$ & \\
$\mathrm{p}_{3}$ & $39-64,51$ & $0.57-0.68,0.65$ & $2.59-2.89,2.79$ & $3.32-3.88,3.54$ & $4.4-7.7,5.7$ & \\
\hline
\end{tabular}

Male imago ( $\mathrm{n}=6-10$ except when otherwise stated)

Total length $1.50-2.00,1.72 \mathrm{~mm}$. Wing length $0.93-1.20,1.03 \mathrm{~mm}$. Total length / wing length 1.62-1.77, 1.65. Wing length / length of profemur $1.82-2.11,1.94$. Thorax pale with brown vittae and postnotum, abdomen pale, legs pale with apical part of femur darker.

Head. AR 0.34-0.39, 0.37. Thirteenth flagellomere 156-200, $183 \mu \mathrm{m}$ long. Temporal setae 4-8, 7; including 3 inner verticals, 1-3, 2 outer verticals; and 12, 1 postorbitals. Clypeus with $13-17,15$ setae. Tentorium 47-78, $57 \mu \mathrm{m}$ long; 10-15, $12 \mu \mathrm{m}$ wide at sieve pore and 6-9, $7 \mu \mathrm{m}$ wide at posterior tentorial pit. Stipes 71-93, $82 \mu \mathrm{m}$ long; 7-11, $8 \mu \mathrm{m}$ wide. Palpomere lengths (in $\mu \mathrm{m}$ ): 22-29, 24; 22-29, 27; 5384,$61 ; 54-75,65 ; 113-133,122$. Fifth palpomere / third palpomere 1.70-2.50, 2.05 .

Thorax. Dorsocentrals 7-10, 8; acrostichals 12-16, 14. Scutellum with 2-4, 3 setae.

Wing. VR 1.50-1.68, 1.60. R with 11-15, 13 setae; R1 with 15-34, 20; R4+5 with 32-67, 44; Sc, and M bare; RM with $0-2,1$; M1+2 with 38-59, 46; M3+4 with 18-27, 20; $\mathrm{Cu}$ with 10-16, 13; Cu1 with 8-16, 11; PCu with 27-46, 36 and An with 18-31, 21 setae. Cells $\mathrm{m}$ with 17 setae, $\mathrm{r} 4+5$ with about $300, \mathrm{~m} 1+2$ with about $250, \mathrm{~m} 3+4$ with about 100 , cu with 80 and an with 30 setae.

Legs. Spur of front tibia 10-29, $18 \mu \mathrm{m}$ long; spurs of middle tibia 4-13, 7 and 12-15, $14 \mu \mathrm{m}$ long; of hind tibia 13-18, 15 and 15-18, $17 \mu \mathrm{m}$ long, all excluding comb. Combs 10-13, $12 \mu \mathrm{m}$ long. Width at apex of front tibia $32-40,34 \mu \mathrm{m}$, of middle tibia 29$40,32 \mu \mathrm{m}$, of hind tibia 33-38, $36 \mu \mathrm{m}$. Lengths and proportions of legs see table 18 .

Hypopygium (figs. 156-159). Tergite IX with 1017, 12 setae. Anal point 44-55, $51 \mu \mathrm{m}$ long, 13-24, $18 \mu \mathrm{m}$ wide at base; 4-9, $6 \mu \mathrm{m}$ wide at apex; crest rounded and basally closed. Laterosternite IX with 12, 1 setae. Phallapodeme 44-66, $59 \mu \mathrm{m}$ long, transverse sternapodeme 35-44, $40 \mu \mathrm{m}$ long. Gonocoxite 55-78, $75 \mu \mathrm{m}$ long, gonostylus 51-74, $69 \mu \mathrm{m}$ long. Superior volsella (fig. 158) 24-36, $30 \mu \mathrm{m}$ long, oval; inferior volsella 47-62, $53 \mu \mathrm{m}$ long; median volsella (fig. 159) 36-53, $45 \mu \mathrm{m}$ long, slightly S-shaped, with distal lamellae fused into single plate with terminal points. Inferior volsella with microtrichia, superior and median volsellae without microtrichia. HR 1.051.16, 1.08; HV 2.20-2.82, 2.44 .

Distribution. - The species is known only from streams and small rivers in southern Ghana.

\section{The phaselus group}

Only the pupa of a new Neotropical species is known. It has anteriorly rugulose frontal apotome, frontal setae, thoracic horn with median bend and spinules in apical $2 / 3$, tergites II-V with paired anterior circular patches of spines, tergite II with posterior shagreen arranged into two groups, about 70 caudal hooklets occupying median half of tergite II, and anal lobe without dorsal seta.

The species included here all have at least some setae between V-shaped anal tergite bands; spatulate anal point with open $\mathrm{V}$-shaped crest or occasionally basally rounded; superior volsella with posterior extension; median volsella only exceptionally reaching apex of superior volsella; and the gonostylus usually is abruptly tapered, often with parallel-sided apical portion.

\section{Rheotanytarsus jongkindi sp. $\mathrm{n}$.}

(figs. 160-163)

Type locality. - GABON: Moyen-Ogooue Region, Ndjele, Auberge St. Jean, Ogooue River.

Type material. - Holotype ô, GABON: MoyenOgooue Region, Ndjele, Auberge St. Jean, Ogooue River, 16 xii 1993, UV light, C. C. Jongkind (ZMBN Type No. 323). Paratypes: $9 \hat{\sigma}$ as holotype (ZSM, BMNH, RMB). D. R. CONGO: Irangi, Flub. Luoho, 1 t , 3-7 iii 1984, light trap, E. G. Burmeister (ZSM).

Diagnostic characters. - See key.

Etymology. - Named after Dr. C. C. Jongkind who collected these insects at his hotel even when it was difficult for him to go outside due to civil unrest in Gabon at the time. 
Table 19. Rheotanytarsus jongkindi, male. Lengths (in $\mu \mathrm{m}$ ) and proportions of legs.

fe ti $\quad t_{1} \quad t a_{2} \quad t a_{3}$

\begin{tabular}{lcccccc}
\hline $\mathrm{p}_{1}$ & $568-800,628$ & $184-352,264$ & $744-824,784(5)$ & $312-352,338(4)$ & $208-240,232(4)$ & \\
$\mathrm{p}_{2}$ & $504-760,575$ & $376-560,420$ & $184-200,192$ & $88-96,93$ & $64-72,66$ & \\
$\mathrm{p}_{3}$ & $568-832,631$ & $424-660,480$ & $248-320,292$ & $160-192,174$ & $112-168,151$ & \\
\hline & $\mathrm{ta}_{4}$ & $\mathrm{ta}_{5}$ & $\mathrm{LR}$ & $\mathrm{BV}$ & $\mathrm{SV}$ & $\mathrm{BR}$ \\
\hline $\mathrm{p}_{1}$ & $184-200,194(4)$ & $88-96,942.82-3.22,3.06(5) 1.83-2.01,1.91(4)$ & $1.03-1.16,1.10(5)$ & - \\
$\mathrm{p}_{2}$ & $40-48,41$ & $24-32,31$ & $0.44-0.50,0.47$ & $4.68-5.48,5.02$ & $4.76-5.33,5.01$ & $4.5-6.6,5.47(6)$ \\
$\mathrm{p}_{3}$ & $88-104,93$ & $48-56,51$ & $0.52-0.74,0.63$ & $2.75-3.72,3.00$ & $3.37-4.29,3.69$ & $5.8-7.0(3)$ \\
\hline
\end{tabular}

\section{Male imago $(\mathrm{n}=9-11)$}

Total length 1.68-2.54, $1.86 \mathrm{~mm}$. Wing length $1.02-1.53,1.16 \mathrm{~mm}$. Total length / wing length 1.34-1.75, 1.60. Wing length / length of profemur 1.76-2.11, 1.88. Thorax dark brown, abdomen and legs dark.

Head. AR 0.51-0.59, 0.55. Thirteenth flagellomere 228-320, $254 \mu \mathrm{m}$ long. Temporal setae 5-7,7; including 2-3, 3 inner verticals; 2 outer verticals; and 12, 2 postorbitals. Clypeus with 13-16, 13 setae. Tentorium 50-90, $71 \mu \mathrm{m}$ long; 14-26, $18 \mu \mathrm{m}$ wide at sieve pore and $6-8,7 \mu \mathrm{m}$ wide at posterior tentorial pit. Stipes 72-94, $83 \mu \mathrm{m}$ long, 14-28, $20 \mu \mathrm{m}$ wide. Length of palpomeres (in $\mu \mathrm{m}$ ): 22-26, 25; 20-32, 26; 64-78, 69; 74-88, 81; 128-156, 137. Fifth palpomere / third palpomere 1.81-2.06, 1.97.

Thorax. Dorsocentrals 8-10, 9, acrostichals 12-14, 14. Scutellum with 2-3, 2 setae.

Wing. VR 1.52-1.59, 1.55. R with 12-18, 15 setae; R1 with 18-34, 22; R4+5 with 30-75, 43; Sc and M bare; RM with $0-2,1$; M1+2 with 34-64, 44, M3+4 with 23-36, 25; Cu with 11-19, 14; Cu1 with 11-16, 15; PCu with 34-62, 40; and An with 20-31, 24 setae. Cells $\mathrm{m}$ with 7 setae, $\mathrm{r} 4+5$ with about $200, \mathrm{~m} 1+2$ with about $120, \mathrm{~m} 3+4$ with 60 , cu with 35 and an with 15 .

Legs. Spur of front tibia 12-18, $13 \mu \mathrm{m}$ long; spurs of middle tibia 8-14, 9 and 12-20, $14 \mu \mathrm{m}$ long; of hind tibia 14-20, 14 and 14-22, $17 \mu \mathrm{m}$ long, all excluding comb. Comb of middle tibia 10-12, $11 \mu \mathrm{m}$ long; of hind tibia 12-16, $14 \mu \mathrm{m}$ long. Width at apex of front tibia 32-40, $34 \mu \mathrm{m}$, of middle tibia 28-36, 30 $\mu \mathrm{m}$; of hind tibia $30-40,34 \mu \mathrm{m}$. Lengths and proportions of legs see table 19.

Hypopygium (figs. 160-163). Tergite IX with 1019, 13 setae. Anal point 44-56, $49 \mu \mathrm{m}$ long; 14-23, 18 $\mu \mathrm{m}$ wide at base; 4-7, $6 \mu \mathrm{m}$ wide at apex; crest Vshaped and open. Laterosternite IX with 1 seta. Phallapodeme 60-76, $66 \mu \mathrm{m}$ long; transverse sternapodeme 29-40, $34 \mu \mathrm{m}$ long. Gonocoxite 71-100, $89 \mu \mathrm{m}$ long; gonostylus 74-107, $98 \mu \mathrm{m}$ long. Superior volsella (fig. 162) 31-37, $33 \mu \mathrm{m}$ long, somewhat triangular; inferior volsella 51-60, $56 \mu \mathrm{m}$ long; median volsella (fig. 163)
31-41, $36 \mu \mathrm{m}$ long, markedly recurved, relatively short, with lamelliform setae fused into plate with apical points. Inferior volsella with microtrichia, superior and median volsellae without microtrichia. HR 0.87 0.96, 0.91; HV 1.74-2.27, 1.94.

Distribution. - The species is known only from Gabon and D. R. Congo.

\section{ZOOGEOGRAPHY OF AFROTROPICAL RHEOTANYTARSUS}

Sæther \& Kyerematen (2000) in order to determine the phylogeny of the genus re-examined all previously described species and using different parsimony analyses obtained twenty-one species groups. Ten of these groups are found in the Afrotropical region.

The phyletic interrelationship of Rheotanytarsus suggests the splitting of their common ancestor into lineages earliest at the very end of the fragmentation of the super-continent Pangaea. The genus shows a warm / eurythermic vicariant Gondwanan pattern with multiple sister group relationships between the South Asia subregion, the Australian and the Afrotropical regions. The East Asia - North America linkage is likely of post-Miocene origin. African - West Palaearctic and South Asian - West Palaearctic vicariance are found in several groups. The evidence for West African - Brazilian vicariance is present, but limited.

In the pentapoda group there apparently is a track between Africa and Eastern South America and further to Central America.

The acuminatus group consists of two species from Tanzania.

The photophilus group shows vicariance patterns between Africa and South Asia and between South Asia and the West Palaearctic. Africa is the area most likely to be part of the original area

The globosus group consists of $R$. bufemoratus sp. $\mathrm{n}$. from Uganda and $R$. globosus Reiss from Chile and Argentina.

In the pellucidus group the single African species, $R$. buculicaudus from Ghana as well as the single Central 
American species, $R$. contrerasi Andersen et Sæther from Mexico, $R$. oss Cranston from Australia and southern Thailand, $R$. minusculus Kyerematen, Sæther et Andersen from Thailand, and $R$. tamasecundus Sasa from Japan, most likely are all a result of peripheral isolation of the widespread $R$. pellucidus (Walker).

In the guineensis s. lat. group there is a vicariance pattern between Africa and the West Palaearctic region, and a possible tropical linkage between Africa and South / East Asia plus Australia.

In the trivittatus group there appears to be a tropical Gondwanan vicariance pattern between Africa and South Asia / Australia.

The ororus group combines 2 species from Thailand with 3 species from West and Central Africa. There apparently is a northern tropical Gondwanaland vicariance pattern.

Both in the thermae group and in the phaselus group there apparently are vicariance patterns between West Africa and Central America. However, the inclusion of a single Afrotropical species in each group may be tentative.

The Afrotropical members of the genus thus show several connections with the West Palaearctic and with the Sino-Indian region, while the connections with South America are more doubtful.

\section{ACKNOWLEDGEMENTS}

We are indebted to the late Dr. F. Reiss, Zoologische Staatssammlung, Munich, Germany; Dr. P. Grootaert, Institut Royal des Sciences Naturelles de Belgique, Brussels, Belgium; Drs B. Pitkin and J. Chainey, The Natural History Museum, London; Dr. E. de Coninck, Koninklijk Museum voor MiddenAfrika, Tervuren, Belgium; Dr. A. D. Harrison, Fish Hoek, South Africa; Dr. P. H. Langton, Coleraine, Londonderry, Northern Ireland; and Dr. J. Mobayed, Montpellier, France, for the loan of material.

Trond Andersen, Associate Professor at the Zoology Department, University of Bergen, Norway read through the preliminary manuscript and gave important suggestions. Gladys Ramirez did most of the slide preparation. Roland Vieyra helped with the scanning of drawings. The Norwegian Universities Committee for Development, Research and Education (NUFU) funded the research.

\section{REFERENCES}

Amakye, J. S., 1993. A checklist of Chironomidae (Diptera: Nematocera) from Ghana based on published records up to 1993. - NUFU Project 38/91, Freshwater Entomology of Ghana, Report 1, 17 pp.

Andersen, T. \& K. A. Johanson. 1993. Caddis flies (Trichoptera) from a mountain rain forest in NE Tanzania. Proceedings of the 7 th International Symposium on Tri- choptera. Junk, The Hague: 59-64.

Balinsky, B. I., 1962. Patterns of animal distribution on the African continent. - Annals of the Cape Provincial Museums 2: 299-310.

Bause, E., 1913. Die Metamorphose der Gattung Tanytarsus und einiger verwandter Tendipedidenarten. - Archiv für Hydrobiologie, Supplement 2: 1-126.

Dejoux, C., 1968. Contribution a' l'étude des premiers états des chironomides du Tchad (Première note). - Hydrobiologia. 31 (3-4): 449-464

Dejoux, C., 1973. Contribution à l'étude des premiers états des Chironomides du Tchad. Description de Tanytarsus (Rheotanytarsus) ceratophylli n. sp. (6e note). - Cahiers ORSTOM, série Hydrobiologie 7: 65-75.

Fittkau, E. J., 1960. Rheotanytarsus nigricauda n. sp. Chironomidenstudien VI. - Abhandlungen naturwissenschaftliche Vereinigung Bremen 35: 397-407.

Freeman, P., 1954. Chironomidae (Diptera) from western Cape province-III. - Proceedings of the Royal Entomological Society of London (B) 23: 17-25.

Freeman P., 1955. Chironomidae (Diptera Nematocera). Exploration du Parc national Albert, Mission G. F. de Witte 83: 1-41

Freeman, P., 1958. A study of the Chironomidae (Diptera) of Africa south of Sahara. Part IV. - Bulletin of the British Museum of Natural History, Entomology 6: 263363.

Freeman, P. \& P. S. Cranston, 1980. Family Chironomidae. - In Crosskey, R. W. (ed.). Catalogue of the Diptera of the Afrotropical region. British Museum (Nat. Hist.), London, 1: 175-202.

Goetghebuer, M., 1954. A. Die Imagines (part). In: Goetghebuer, M. \& Lenz, F. Tendipedidae (Chironomidae). b) Subfamilie Tendipedinae (Chironominae) (part). - Die Fliegen der palaearktischen Region 3(1)(13c): 129-168.

Hall, J. B. \& Swaine, M. D., 1976. Classification and ecology of closed-canopy forests in Ghana. - Journal of Ecology 64: 913-951.

Hall, J. B. \& Swaine, M. D., 1981. Distribution and ecology of vascular plants in a tropical rain forest. Forest vegetation in Ghana. - Junk, The Hague. 383 pp.

Hamilton, A. C., 1982. Environmental history of East Africa. - Academic Press, New York, 328 pp.

Hamilton, A., 1989. African Forest. In: Lieth, H. \& Werger, M. J. A. (eds). Tropical rain forest ecosystems. Biogeographical and Ecological studies. - Ecosystems of the World 14B: 155-182.

Harrison, A. D., Keller, P. \& Dimovic, D., 1960. Ecological studies on Olifantsvlei, near Johannesburg. - Hydrobiologia 15: 89-134.

Harrison, A. D., 1964. An ecological survey of The Great Berg River. - Monographs in Biology 14: 143-158.

Harrison, A. D., 1966. Recolonization of a Rhodesian stream after drought. - Archiv für Hydrobiologie 62: 405-421.

Hopson, A. J., 1967. The fisheries of Lake Chad. - In: Reed, W. (ed.). Fishing and fisheries of Northern Nigeria, Ministry of Agriculture, Gaskiya Corp., D. R. Congo: pp 189-200.

Hynes, J. D., 1972. Studies on the faunal ecology of the Pawpawn River. - Unpublished M. Sc. thesis, University of Ghana.

Kieffer, J. J., 1909. Diagnoses de nouveaux Chironomides d'Allemagne. - Bulletin de la Société d'Histoire Naturelle de Metz 26: 37-56.

Kieffer, J. J., 1918. Chironomides d`Afrique et d'Asie conservés au Museum National Hongrois de Budapest. - An- 
nales Historico-Naturales Musei Nationalis Hungarici 16: 31-136.

Kingdon, J., 1990. Island Africa. The evolution of Africa's rare animals and plants. - William Collins Sons \& Co. Ltd., London, 287 pp.

Kullberg, A. 1988. The case, mouthparts, silk and silk formation of Rheotanytarsus muscicola Kieffer (Chironomidae: Tanytarsini). - Aquatic Insects 10: 249-255.

Kyerematen, R., O. A. Sæther \& T. Andersen, 2000. A review of the Rheotanytarsus pellucidus group (Diptera: Chironomidae). - In Hoffrichter, O. (ed.) Late $20^{\text {th }}$ Century Research on Chironomidae: an Anthology from the 13th international Symposium on Chironomidae. Shaker Verlag, Achen. (in press)

Langton, P. H. 1991., A key to pupal exuviae of West Palaearctic Chironomidae. - P. H. Langton, Huntingdon, Cambridgeshire, 386 pp.

Langton, P. H. 1994., If not 'filaments', then what? - Chironomus 6: 9.

Langton, P. H., 1998. Mea Culpa. (The Chironomus confessional).- Chironomus 11: 16-17.

Langton, P. H. \& Armitage, P. D, 1995. Rheotanytarsus rioensis (Diptera: Chironomidae), a new species of the pentapoda group from the Canary Islands. - British Journal of entomological natural History 8: 11-17.

Lehmann, J., 1979. Chironomidae (Diptera) aus Fliezgewässern Zentralafrikas (Systematik, Ôkologie, Verbreitung und produktionsbiologie). Teil I: Kivu-Gebiet, Ost D. R. Congo. - Spixiana Supplement 3: 1-144.

Leonard, J., 1965. Contribution de la subdivision phytogeographique de la region guinea-congolaise aprés la répartition géographique d'Euphorbiacées d'Afrique tropical. Webia 19: 627-649.

Mabberley, D., 1992. Tropical rain forest ecology. 2nd Edition. - Blackie, Glasgow and London, 300 pp.

McLachlan, A. J., 1965. The ecology of the bottom fauna of Lake Kariba. Records of a Kariba Res. Symp., 8-9 June 1965. - Publications from the Lake Kariba Fisheries Research Institute, Kariba: 58-59.

McLachlan, A. J., 1969. The effect of aquatic macrophytes on the variety and abundance of benthic fauna in a newly created lake in the tropics (Lake Kariba). - Archiv für Hydrobiologie 66: 212-231.

Petr, T., 1969. Development of bottom fauna in the manmade Volt Lake in Ghana. - Verhandlungen der internationalen Vereinigung für Limnologie 17: 272-282.

Petr, T., 1970. Chironomidae (Diptera) from light catches on the man-made Volta Lake in Ghana. - Hydrobiologia 35: 449-468.

Rossaro, B. 1988. A contribution to the knowledge of chironomids in Italy. In: Fittkau, E. J. (ed.): Festschrift zur
Ehren von Lars Brundin. - Spixiana, Supplement 14: 191-200.

Sæther, O. A., 1977. Female genitalia in Chironomidae and other Nematocera: morphology, phylogenies, keys. Bulletin of the Fisheries Research Board of Canada 197: 1-209.

Sæther, O. A., 1980. Glossary of chironomid morphology terminology (Diptera: Chironomidae). - Entomologica scandinavica, Supplement 14: 1-51.

Sæther, O. A., 1990a. Phylogenetic trends and their evaluation in chironomids with special reference to orthoclads. - Acta biologica Debrecina, Supplementum Oecologica Hungarica 2: 53-75.

Sæther, O. A., 1990b. A review of the genus Limnophyes Eaton from the Holarctic and Afrotropical regions. - Entomologica scandinavica, Supplement 35: 1-135.

Sæther, O. A. \& Kyerematen, R. A. K. 2000. Review of the genus Rheotanytarsus Thienemann et Bause, 1913 (Diptera: Chironomidae). Species lists, phylogeny, keys, zoogeography. - Tijdschrift voor Entomologie (submitted).

Thienemann, A., 1954. Chironomus. Leben, Verbreitung und wirtschaftliche Bedeutung der Chironomiden. Binnengewässer 20: 1-834.

Thomas, J. D., 1966. Some preliminary observations on the fauna and flora of a small man-made lake in the West African savannah. - Bulletin Institute francais Afrique noire, Série A. 28: 542-562.

Wasser, S. K. \& Lovett, J. C., 1993. Introduction to the biogeography and ecology of the rain forests of eastern Africa. - In: Lovett, J. C. \& Wasser S. K. (ed.). Biogeography and ecology of the rain forests of eastern Africa. Cambridge University Press, Cambridge: pp. 3-7.

Whyte, S. A., 1971. The ecology of chironomids in a small man-made lake - Danfa reservoir. - Unpublished M. Sc. thesis, University of Ghana. 320 pp.

Whyte, S. A., 1975. Distribution, trophic relationships and breeding habits of the fish population in a tropical lake basin (Lake Bosumtwi - Ghana). - Journal of Zoology, London 177: 25-56.

Whyte, S. A., 1980. The density and abundance of the chironomid fauna of the stony littoral shores of temperate and tropical lakes. - Unpublished Ph. D. thesis, University of Ghana. $436 \mathrm{pp}$.

Received: 3 January 2000

Accepted: 30 March 2000 